Florida International University FIU Digital Commons

FIU Electronic Theses and Dissertations

University Graduate School

2-15-2010

\title{
Translating International Norms: Filters to Women's Rights in Lebanon
}

Rita A. Sabat

Florida International University, rsaba002@fiu.edu

DOI: $10.25148 /$ etd.FI10041622

Follow this and additional works at: https://digitalcommons.fiu.edu/etd

Part of the International Relations Commons

\section{Recommended Citation}

Sabat, Rita A., "Translating International Norms: Filters to Women's Rights in Lebanon" (2010). FIU Electronic Theses and Dissertations. 155.

https://digitalcommons.fiu.edu/etd/155

This work is brought to you for free and open access by the University Graduate School at FIU Digital Commons. It has been accepted for inclusion in FIU Electronic Theses and Dissertations by an authorized administrator of FIU Digital Commons. For more information, please contact dcc@fiu.edu. 


\section{FLORIDA INTERNATIONAL UNIVERSITY}

Miami, Florida

TRANSLATING INTERNATIONAL NORMS: FILTERS TO WOMEN'S RIGHTS IN LEBANON

A dissertation submitted in partial fulfillment of the requirements for the degree of DOCTOR OF PHILOSOPHY

in

INTERNATIONAL RELATIONS

by

Rita A. Sabat

2010 
To: Dean Kenneth Furton

College of Arts and Sciences

This dissertation, written by Rita A. Sabat, and entitled Translating International Norms: Filters to Women's Rights in Lebanon, having been approved in respect to style and intellectual content, is referred to you for judgment.

We have read this dissertation and recommend that it be approved.

Charles G. Macdonald

Mohiaddin Mesbahi

Aisha Musa

Elisabeth M. Prugl, Major Professor

Date of Defense: February 15, 2010

The dissertation of Rita A. Sabat is approved.

Dean Kenneth Furton College of Arts and Sciences

Interim Dean Kevin O'Shea

University Graduate School

Florida International University, 2010 


\section{DEDICATION}

To my beloved parents and my beautiful angel Samira 


\section{ACKNOWLEDGMENTS}

I completed this journey because of several people's time, dedication, commitment, sacrifice, and support so I will try to acknowledge everyone that played an integral role in helping me get to the end. If I happen to skip over someone I apologize ahead of time. First and foremost I am eternally grateful to my main advisor and the one who was probably the first to help me find myself in what seemed at times a foreign world. Thank you for helping me go on with life's every turn and bump and when things seemed like they did not make any sense you saw the dissertation in a whole new light. Dr. Mesbahi, thank you for your stern and demanding but gentle pushing, you put it best when you said doing this is a privilege and not a right. Dr. MacDonald thank you so much for your support and caring ways, you always helped me see the big picture at the end of the day. Dr. Musa, I am glad you came into this project at the right time, thank you for your time. To the department that housed me for these past few years I have always said that I was lucky to be part of your family. Michelle for always running around when I needed you and for not forgetting to ask me how I was doing, I am eternally grateful. Thank you to those that chose to help fund this, Florida International University Dissertation Year Fellowship, the Exxon Foundation Fellowship, and Jack D, Gordon Institute for Public Policy and Citizenship Studies.

Without the sacrifice of my family and the support of my friends life would not be the same. I must first thank my parents for standing by me all these years even when they saw me making blunders. They truly did what I hope I will do for my own daughter. To my brothers who have stood by me through thick and thin I love you. To my friend 
who travelled the journey to motherhood with me. Alla over the last of couple of years you have put into this friendship more than you have gotten out of it, but your style, grace, and knowledge have been my inspiration. You helped me be strong when I needed it and you helped me get past a day, a week, and a month by pushing me along. I hope you know how much you mean to me. Majid you lead by example, thank you for being solid and dependable, but silently standing by along the way. My new and old friends that are helping me adjust to this new life of mine what would I do without you. Annie thanks for always making sure I don't forget about work left undone and for those afternoons with the kids and coffee. Jad what can I say but you helped make sense out of every new day. You helped me see that I can fit in and love this new life of mine. Thank you for every laugh. Joe you are one of my oldest and dearest friends, we ended up completing our PhD's together and getting our first assignment together. You know me better than anyone else in this world. Finally, to my beautiful treasure who might read this one day. You are my reason for completing this and for waking up excited every morning. Thank you for picking me. 
ABSTRACT OF THE DISSERTATION

\section{TRANSLATING INTERNATIONAL NORMS: FILTERS TO WOMEN'S RIGHTS IN LEBANON}

by

Rita A. Sabat

Florida International University, 2010

Miami, Florida

Professor Elisabeth Prugl, Major Professor

In 1979 the United Nations passed the Convention on the Elimination of All Forms of Discrimination against Women (CEDAW), an international bill of rights for women. Much scholarship has focused on the degree to which states have adopted these new international gender norms, but have paid little attention to the fact that norms change in the processes of implementation. This dissertation focuses on that process assessing the translation of international gender equality norm in Lebanon.

The study traces global gender equality norms as they are translated into a complex context characterized by a political structure that divides powers according to confessional groups, a social structure that empowers men as heads of families, and a geopolitical structure that opposes a secular West to the Muslim East. Through a comparison of three campaigns - the campaign to combat violence against women, the campaign to change personal status codes, and the campaign to give women equal rights to pass on their nationality - the study traces different ways in which norms are translated as activists negotiate the structures that make up the Lebanese context. Through ethnographic research, the process of norm translation was found to produce various 
filters, i.e., constellations of arguments put forward by activists as they seek to match international norms to the local context. The dissertation identifies six such filters and finds that these filters often have created faithless translations of international norms. 


\section{TABLE OF CONTENTS}

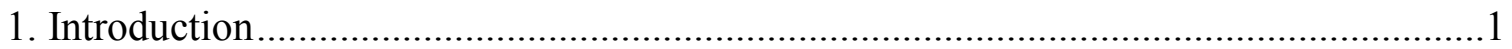

Lebanon: Confessionalism as a Unique Political Structure............................................... 6

Lebanon's Personal Status Codes ...............................................................................

Culture of Violence and Political Instability: Old and New ............................................10

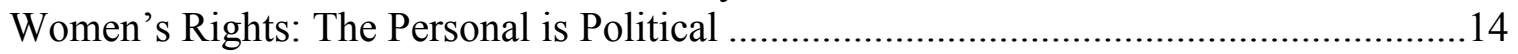

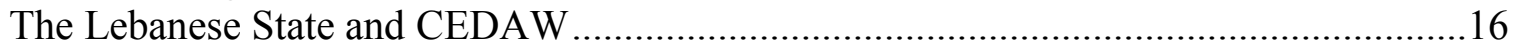

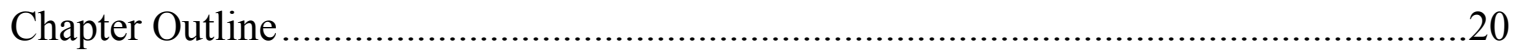

2. Translating Gender Equality Norms: Filters, Translations, and Structures ...................23

Global Gender Equality Regime: Establishing the Regime .............................................24

Translating International Norms: Models in IR and Social Movements ...........................31

Translating International Norms a Framework..............................................................34

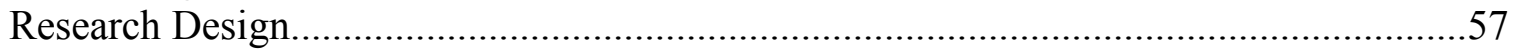

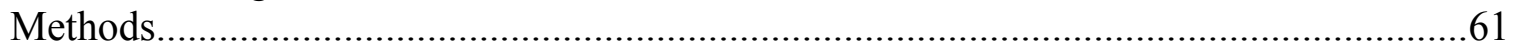

3. Campaigns Combating Violence Against Women …………………..........................65

Campaigns to Eliminate Violence Against Women in Lebanon ........................................69

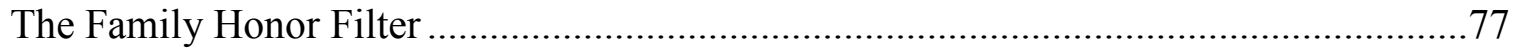

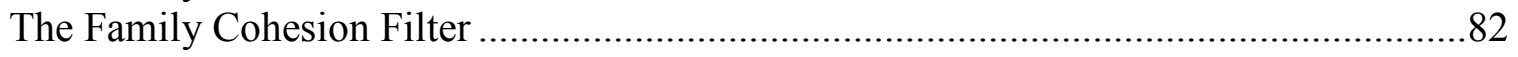

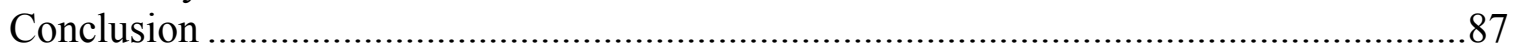

4. Campaigns for Gender Equality Norms in Personal Status Codes .................................89

Lebanon, Convention to Eliminate All Forms of Discrimination Against Women and Personal Status Codes: Tackling Women's Equality in Family Law .................................93

Lebanon's Personal Status Codes Campaigns.................................................................96

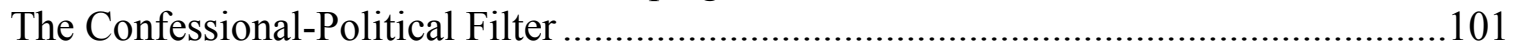

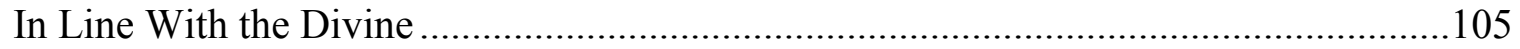

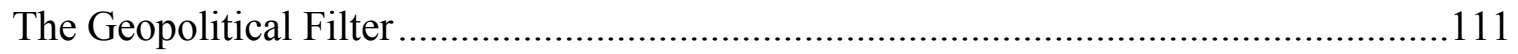

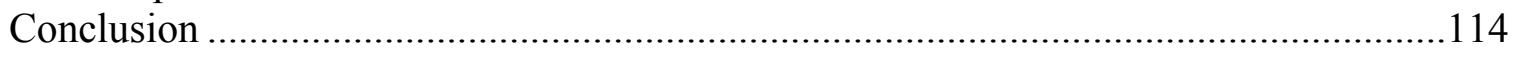

5. Campaigns for Gender Equality Norms in Nationality Law …………......................116

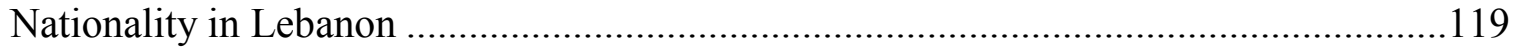

Campaigns on Nationality Law ……….............................................................121

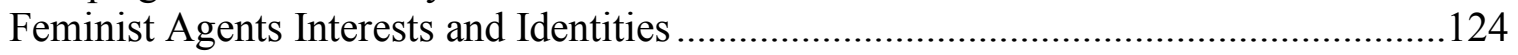

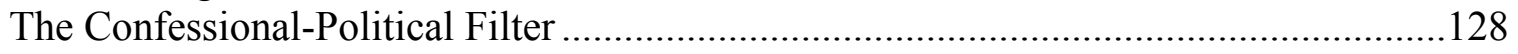

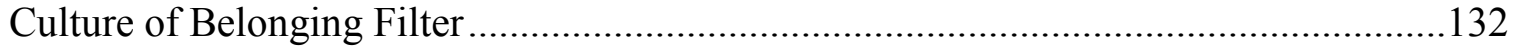

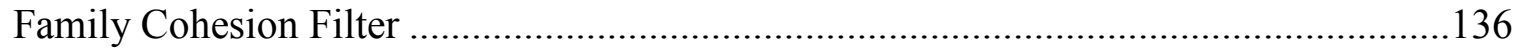

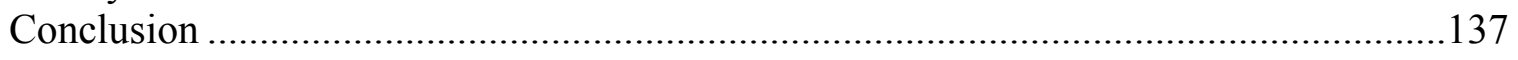

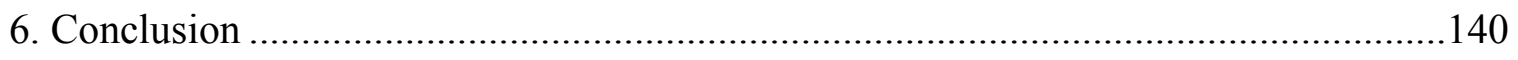

Looking at Structures: State, Social, and International..................................................141 
Filters: Family Cohesion, Family Honor, Geopolitical, Confessional Political, Culture of Belonging, and In Line with the Divine ...................................................................146

International and Regional Influence in Lebanon........................................................152

Policy Recommendation and Suggestions for Future Research ......................................154

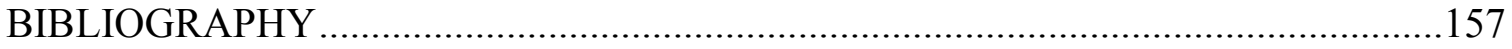

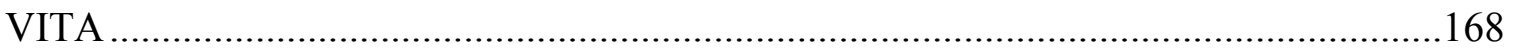




\section{Chapter 1}

$\underline{\text { Introduction }}$

A global gender equality regime has been established by the human rights conventions also known as the international bill of rights for women, namely the Convention on the Elimination of All Forms of Discrimination against Women (CEDAW, 1979) and the Optional Protocol to the International Convention on the Elimination of All forms of Discrimination against Women (1999). While 186 and 99 state parties have ratified CEDAW and the optional protocol, respectively the implementation of these conventions has been uneven. Accordingly scholars have focused on issues of enforcement and implementation with little attention paid to the process of diffusion that can be a matter of degree and translation. This dissertation emphasizes that process as an important component in assessing the translation of international gender equality norms into complex domestic contexts.

The current study examines how global gender equality norms have translated in Lebanon. Instead of focusing on the degree to which CEDAW has been implemented through legal action as a whole, I focus on a set of gender equality norms included in the convention to assess a process of diffusion. This process involves a translation of international norms not only by the government, but through the crucial work of movements and activists. In order to trace this process I have selected to study three campaigns, the campaign on combating violence against women, the campaign for gender equality in (family and marriage) personal status laws, and the campaign for gender equality in nationality. I selected these three campaigns because they have 
mobilized women across Lebanon and have formed around the three main issue areas of concern for women in the country. The campaign to combat violence against women has taken on two facets: one addresses gender inequality existent in the legal penal code and the other addresses the lack of legislation to protect violence against women within the family. The campaign not only seeks to address the legislative institutions but also the norms of society. The second campaign seeks to address the translation of gender equality in family and marriage within the personal status codes. Lebanon's familial matters are all governed by confessional communities and their laws commonly called the personal status laws. The campaign seeks to change inequalities perpetuated through these laws. Another part of the campaign is an appeal to institute a uniform civil law that could govern all Lebanese men and women equally regardless of confessional attachment. The last campaign examined is gender equality in Lebanon's nationality law. This campaign addresses reforming the nationality law so that women become able to pass on their nationality to their foreign husbands and children. In addition, the campaign more broadly looks at the status of women and their relationship to the state as independent citizens with rights and obligations.

This work is important because it addresses two issues regarding international norms. First, it shows that norms do not simply diffuse into local contexts when international conventions are signed and ratified. Instead, it requires considerable effort on the part of political actors to accomplish such diffusion. Second, global gender equality norms can change in the process of translation, a process that is informed by the motives of actors and constellations of arguments that make the norms palatable in 
domestic contexts. As will be discussed later most of the literature in this area postulates that once a convention is signed and ratified implementation will ultimately take place. This formulation renders norms static with no possibility of a transformational stage. In other words, scholars of norms make several problematic assumptions: First, they assume that that there is agreement on the definition of global gender equality norms. However, although these norms are defined in international documents, they are subject to broad interpretation. Second, scholars typically ignore domestic contexts and the role they play in shaping norms as they are translated into such contexts. Third, scholars typically disregard identities and interests of actors involved in promoting the norms and thus fail to see how these affect the process of implementation. Finally, existing scholarship tends to forget that regional and global geopolitics shape the domestic context and thus have an effect on processes of norm implementation. ${ }^{1}$ In addressing these issues, my dissertation advances the theoretical understanding of the way in which international norms diffuse globally.

The dissertation also makes a contribution to feminist literatures in that it shows the agency of women in the Middle East, who are often portrayed as passive victims of patriarchal forces. It brings into view the Middle Eastern/Arab women's movement to get a firsthand account of the way women retain political agency. It addresses questions that surround the political subject position of Middle East feminists engaged in this translation. By political subject position of Middle East Feminists I mean the way they

\footnotetext{
${ }^{1}$ See also Zwingel, Suzanne. How do international women's rights norms become effective in domestic contexts? An analysis of the Convention on the Elimination of all Forms of Discrimination against Women (CEDAW), Bochum University, Dissertation 2005
} 
define themselves in light of conceptions that centrally define their agency in relation to the state and to society in their attempts to achieve gender equality. This study reveals the multiple subject positions of the activists where each norm is concerned and reformulates the image of women in the Middle East accordingly.

This work also revisits the question of universally accepted rights in an era defined by dichotomies. Advocates of the universality of human rights refer back to the origins of the term and its definition as put forth by the Universal Declaration of Human Rights (UDHR) in $1948 .{ }^{2}$ To them human rights are universal, i.e., they are based on the notion that they belong to every human being in every human society. By nature these rights are provided equally without regard to race, sex (gender), national origin, or religion. But the lack of attention given to religion in international law has become a matter of debate and problematic for claims to the universality of human rights. ${ }^{3}$ Islamic human rights scholars have urged that there be a synergy between the right to religion and the right to freedom. ${ }^{4}$ Such a synergy cannot emerge from abstract logic or legal reasoning, but is best worked out in concrete, local circumstances. The current study illustrates how social activism entails a negotiation between universal human rights

\footnotetext{
${ }^{2}$ Donnelly, Jack. "The Relative Universality of Human Rights" Human Rights Quarterly 29, no. 2 (2007) Lebanon's familial matters are all governed by confessional communities and their laws commonly called the personal status laws.

${ }^{3}$ Sunder, Mahdavi "Piercing the Veil." In Just Advocacy? : Women's Human Rights, Transnational Feminisms, and the Politics of Representation, edited by Wendy S. Hesford and Wendy Kozol. New Brunswick, N.J.: Rutgers University Press, 2005. An-Na'im,Abdullahi A "The Synergy and Interdependence of Religion, Secularism, and Human Rights: Prospects for Islamic Societies", Common Knowledge, 2005

${ }^{4}$ Ibid
} 
norms and religious values. In this way, it takes up the challenge of Islamic human rights scholars and their call to revisit static conceptions of human rights norms.

Lebanon lends itself to this kind of examination particularly well because in many ways, it stands at the fault lines between East and West, religiosity and secularism, particularism and universalism, which have fueled geopolitics in recent years. The legacies of Ottoman and French domination are reflected in the country's laws, constitution, and society which encompasses a deeply embedded patriarchal kinship structure with a hierarchical ordering based on gender and age. It is a society where rights are treated as something to be earned rather than being inherently yours simply because you are born human. The struggle of women's organizations for such rights has been shaped by Lebanon's political structure and has been intertwined with the country's history of civil conflict. The following section provides a brief background of Lebanon's historical social and political development, including a review of the development of gendered legal codes and the articulation of feminist challenges.

\section{Lebanon: Confessionalism as a Unique Political Structure}

Lebanon was created as an administrative entity at the end of World War I with the collapse of the Ottoman Empire ushered in by the principles of self determination and decolonization. The French were responsible for the transition of the country to independence during the mandate period, and it gained its independence on November 22, 1943. Today, Lebanon is a parliamentary republic, with a unicameral National Assembly (Chamber of Deputies) composed of 128 deputy members elected by the people every four years. The executive branch is composed of the President who is 
elected by Parliament and serves a six year term. The President governs the country with the Prime Minister and the executive branch. There also is a Council of Ministers composed of 30 members appointed by the Prime Minister in consultation with the President. The consociational democracy established with independence is designed to have government positions distributed based on a formula of proportional representation with the President elected from the Christian Maronite community, the Prime Minister from the Sunni community, and the Speaker of the House from the Shi'a community. All of the eighteen confessions are proportionally represented in the Council of Ministers and the Chamber of Deputies according to the last official census taken in Lebanon in 1932. The census has always been a point of contention and the issue of proportional representation was revisited in the 1990 constitutional amendment by the Taif Accord. The revised constitution re-apportioned the ratio of representation from $6: 5$ to $5: 5$ Christian:Muslim within the executive and legislative branches. The revised accord also stripped the President of most his powers by having the Prime Minister report to parliament instead of the President. ${ }^{5}$ While the Taif Accord also envisioned doing away with the confessional proportional system on the one hand, on the other is strengthened the power of religious communities and leaders by allowing the religious leaders the right to object to any legislative changes or proposals that are tied to family affairs. ${ }^{6}$ Lebanon's consociational democracy has proven to be most challenging fueled with instability and years of political instability and civil strife. An aspect often overlooked in

\footnotetext{
${ }^{5}$ Carnegie Arab Political Systems: Baseline Information and Reforms Lebanon www.carnegieendowment.org/arabpoliticalsystems

${ }^{6}$ Ofeish, Sami A. "Lebanon's second republic: secular talk, sectarian application "Arab Studies Quarterly (ASQ). 21.1 (Wntr 1999): 97(2).
} 
histories of Lebanon's conflictual system is the extent to which the confessionalist basis of its form of democracy relied on the subordination of women. The next section gives a brief overview of Lebanon's confessional communities and their responsibilities in family law referred to as the Personal Status Codes.

\section{Lebanon's Personal Status Codes}

The story of Lebanon's history cannot be dissected into neat little compartments where everything can be simply explained away, much like discussing women's rights cannot be removed from the broader context of Lebanon's local, regional, and global complexity of interaction. Lebanon's political history of competition, fear, patronage, and civil strife bolstered by the communal context is ongoing and seeps into even the most seemingly benign social issues. ${ }^{7}$

Prior to its colonial occupation by the French, Lebanon's history was enmeshed with three centuries of governance under the Ottoman Empire. This is where the foundation for the structure of its family laws can be found. The French Mandate of 1918-1943 had an effect on Lebanon's overall body of laws; however, the Ottoman Law of Family Rights of 1917 remained largely intact. ${ }^{8}$ When the country gained its first constitution in 1926, it resembled the Ottoman millet system in that confessional

\footnotetext{
${ }^{7}$ Kamal Salibi, A House of Many Mansions: The History of Lebanon Reconsidered, Berkeley, CA University of California Press: 1988. Samir Khalaf, Civil and Uncivil Violence in Lebanon: A History of the Internationalization of Communal Conflict, NY: Columbia University Press, (2002)

${ }^{8}$ Lama Abu-Odeh "Crimes of Honor and the Construction of Gender in Arab Societies", Mai Yamani ed., Feminism and Islam: Legal and Literary Perspectives, (NY: New York University Press, (1997),141-194
} 
communities were given the right to govern familial issues. ${ }^{9}$ This system remains in effect today as Lebanon continues to defer all familial and personal issues to the confessional communities.

Even though there are differences, all of the confessional laws in Lebanon were drawn from a general law that can be traced back to the Ottoman Law of Family Rights of 1917. There are nineteen confessions, eighteen of them recognized and an extra made available for the creation of a "common law community" which will include those individuals that choose not to be registered or those confessions that have yet to be recognized. ${ }^{10}$ The confessions include among Christians, the Maronite, Greek-Catholic, Armenian-Catholic, Syriac-Catholic, Latin Catholic, Chaldean-Catholic, GreekOrthodox, Armenian-Orthodox, Syriac-monophysite, Assyrian, Protestant, CopticOrthodox, and the Chaldean-Orthodox communities. In addition, there are the Sunni, Shi'i, Alawites, the Druze, and the Israelites. Of these eighteen confessions up to fifteen confessions have personal status code. ${ }^{11}$ Six of the different Christian catholic confessions apply the law of the Eastern Church with one whose point of reference is the Latin church. Where there are issues not clearly defined in one of the confessions their source of return is the Catholic church. For example the Maronite Personal Status Law

\footnotetext{
${ }^{9}$ However it must be pointed to that even in the French system prior to separation of church and state there was a similar division with a statue personelle that govern familial matters separately.

${ }^{10}$ The constitution provides a space for the creation of a civil law that has not been realized as of yet.

${ }^{11}$ I use the term up to fifteen confessions that have a personal status code because of discrepancies in the number of existing personal status laws where most the activists and the literature examined at times conflicts on the actual number that exists. In the literature you find that the numbers mostly vary between 12 and 15 in existence.
} 
does not offer directives on alimony so Maronites refer to the Catholic church or Catholic jurisprudence. The Ottoman Family Code of 1917 is a major source to return to for both Muslims and Christians. And when there are cases with no clear precedent the Sunnis refer back to the Hanafi courts and the Shi'i to Ja'afari courts, both of which have several authoritative sources. Multiple authoritative sources means that Shiite sources can come from Iran or from within Lebanon, and the Sunnis' authoritative source can also come from Saudi Arabia. ${ }^{12}$

Indeed, when one confession has no precedent on a specific issue, it typically looks to another confession for clarification or guidance. Lebanon has no secular civil marriage law and all citizens must be registered to one of the recognized confessions at birth. Those who would like a civil marriage must travel outside of the country to do so and in cases of dissolution the laws of that foreign country will be applied by the Lebanese courts.

Lebanon's history of violence and civil strife must be understood in the context of the combined effects of a consociational democracy based on confessionalism, and the empowerment of confessional patriarchs by giving them authority over family issues. The next section is an overview of this history and of the actors involved.

\footnotetext{
${ }^{12}$ For more on Lebanon's Personal Status Codes see portal.unesco.org/shs/fr/files/8090/11313662721Women_in_Personal_Status_Laws.pdf/Women_ in_Personal_Status_Laws.pdf last accessed February 20, 2009
} 
Culture of Violence and Political Instability: Old and New

Civil War 1975-1990

Crucial to understanding Lebanon's civil war is the country's demographic distribution. Of the eighteen confessions described above, the Christians, Jews, Druze, Shi'a, and Sunni communities constitute minorities. Lebanon has also provided refuge and citizenship to other minorities such as the Armenians who escaped after the genocide and an initial group of Palestinians who were of Lebanese descent. Shi'a and Christian Maronite presence in what is now Lebanon can be traced back to the seventh century. Maronite attachment to the church and loyalty to the clergy solidified its confessional leader's political position. The Druze migrated to the area in the tenth century and the Sunni presence on the coast gained power during Ottoman rule. The state is made up of a group of minority confessional communities with no single confessional community being described as a majority. While the last formal census taken was in 1932 the state and other agencies have published estimates over the years. The estimates have been rife with problems as they are either incomplete not taking into account the youth or they are inflated as they are not able to identify those who have emigrated. According to Mark Farha (2008) "Above and beyond the methodological problems inherent in almost all these demographic studies, obvious political implications can prejudice the accuracy and interpretation of statistical data." He also makes clear that without an update census most would agree that there are three main confessions in power Christians, Sunni's, and 
Shiites with estimates ranging between twenty five and thirty five percent of the population per group. ${ }^{13}$

Lebanon has been used as the battleground area for Palestinians and Israeli's over the years. However, until the civil war in 1975, Lebanon's consociational democracy was referred to as the most stable in the Arab world and usually dubbed the Switzerland of the Middle East. Lebanon tried to maintain a neutral stance in regional conflicts, however, found itself drawn into proxy wars with an increasing Palestinian refugee population and the relocation of the Palestinian Liberation Operation from Jordan to Lebanon after the conflict in Jordan in 1971. The causes of the civil war of 1975 include several factors but one cannot disentangle the civil strife from the external forces that have played a role in this war. As Rustum-Shadeh contends "The Lebanese did not go to war to change their political system; they joined a war fought on their land by the Arab states, Israel, and the superpowers to defend certain policies and ideologies" (RustumShehadeh 1999, 10). ${ }^{14}$ This does not mean that Lebanon did not experience communal conflict over the years but one cannot isolate the role of external forces in the civil conflict that ensued over the sixteen years. Palestinian presence in Lebanon is one of the most referred to reasons for instability and conflict historically and presently, as they now amount to approximately ten percent of the population. Major politicians have referred to "the Christians' feeling of fear, the Muslims' feeling of inequality, and the exploitation of

13 Mark Farha, "Demography and Democracy in Lebanon", Mideast Monitor, Vol. 3, No.1 (January-March 2008) http://www.mideastmonitor.org/issues/0801/0801_2.htm

${ }^{14}$ Rustum-Shehadeh, Lamia, Women and War in Lebanon, Gainesville, FL, University of Florida Press: 1999, 10 
Lebanon's unique qualities of freedom, prosperity, and progress that helped turn Lebanon into an arena for others to fight in; and external, where the Palestinian factor was foremost" (Rustum-Shehad 1999, 12) as the primary factors leading to war. ${ }^{15}$ The same factors are operative and still driving political instability and the weak state of Lebanon today.

Tai'f Accord: Syrian Tutelage, Israeli Occupation, and the Doha Agreement

The long civil war lasting from 1975 came to a close in 1990 with the Tai'f Agreement. However, The Tai'f Accord ended the civil war and is the last amendment to have been made to the constitution. The fundamental changes as a result of the accord was the redistribution of the parliamentary seats and the cabinet equally between Christians and Muslims, the reduction in the powers of the President balanced off by the increase in powers of both the Prime Minister and the Speaker of House now commonly referred to as the governing of the troika. Syrian presence and Israeli occupation remained part of the equation. Israel withdrew its forces in 2000 following a protracted confrontation with Hizballah dubbed as Lebanon's Resistance Force. The assassination of Prime Minister Rafik Hariri in February of 2005 was a turning point in Lebanon's political history which created several movements that led to the withdrawal of Syrian forces from Lebanon and to a political standoff between two competing movements, one dubbed the opposition March $8^{\text {th }}$ led by Hizballah with Syrian and Iranian support, and the other the majority of March $14^{\text {th }}$ led by Prime Minister Saniora backed by Western and Saudi Arabian support. These two movements have changed the confessional balance

${ }^{15}$ Ibid 
and dividing the Christians, with the Phalangists groups headed by Amin Gemayel and Samir GaeGae a part of March $14^{\text {th }}$, and General Aoun the leader of the Free Patriotic Movement creating an alliance with Hizballah and March 8th. The standoff created a stalemate that brought the government to a full halt with parliament not convening for almost two years. The end of President's Lahoud's term had him leaving office in 2007 with no replacement President whose election kept being postponed 19 times. The standoff was accompanied by a string of assassinations and bombings targeting antiSyrian officials and leaving forty parliamentarians fearful for their life hiding out in one of Beirut's luxury hotels for many months. The conditions kept escalating prompting people to speak of Lebanon on the brink of another civil war. On May $8^{\text {th }}, 2008$ rioting broke out on the streets pitting supporters of each side against each other and resulting in the takeover of some Beirut Sunni neighborhoods by the Opposition of March $8^{\text {th }}$. The stalemate ended with a meeting in Doha, Qatar that produced an agreement amongst the opponents and the formation of a national unity government. Upon their return the election of President Michel Suleiman took place on May $25^{\text {th }} 2008 .^{16}$

This brief political analysis shows how internal confessional dynamics coupled with external intervention have affected the stability and the strength of the state of Lebanon. Not surprisingly, the recent conflicts have had repercussions for the women's rights movement and the push for gender equality. The next section traces the development of women's organizations and the struggle for gender equality.

16 For more information on the political crises its origins and analysis see the following http://www.usip.org/resources/facing-abyss-lebanons-deadly-political-stalemate http://www.cbsnews.com/stories/2008/05/08/world/main4080303.shtml, http://www.npr.org/templates/story/story.php?storyId=90694409\&ps=rs 
Women's Rights: The Personal is Political

Women's organizations in Lebanon can be traced back to independence. The first two organizations included the Lebanese Arab Women Union established in 1929 that integrated with the Lebanese Women's Solidarity group to form Lebanese League for Women's Rights in 1947 involved in the fight for independence. The Lebanese women's movement goals and visions resembled the global women's movement in the struggle for full social and political rights. ${ }^{17}$ The Lebanese League for Women's Rights was a key player in many campaigns including the fight for the right to vote for women in 1952, aiding the development of women in agriculture and manufacturing in the 1970s, and the push for a uniform civil law in the 1990s. A second organization, the Lebanese Women's Council was established in 1952 as an umbrella organization that now includes approximately 150 women's organizations from all sectors. The Lebanese Women's Democratic Gathering was established in 1975 right before the beginning of the civil war. The end of the civil war came with the proliferation of non-governmental organizations and the ability for the women's movement to refocus on gender equality. The Lebanese Council to Resist Violence Against Women established in 1997 was one of the first organizations to address the issue giving it recognition and legitimacy in the country. Since then while several organizations have broadened their missions to include violence against women KAFA: Enough Violence and Exploitation established in 2005 is the second organization that is very visible and active on the issue. The Collective for Research and Training on Development is another very active organization that deals

\footnotetext{
${ }^{17}$ http://afkar.omsar.gov.lb/English/SiteMenu/Publications/Pages/Khatoun\%20Hyadar\%20Eng.as px
} 
with gender issues in Lebanon. All of these organizations have gained momentum and strength with the Fourth Global Women's Conference in Beijing (1995) and the Platform Plan of Action. Several activists from women's organizations participated in the conference and upon their return worked to adhere to the Beijing recommendations. The state formally established the National Commission for Lebanese Women in 1996. Established by the Lebanese Council of Ministers it has a broad mission which includes reviewing legislation to amend existing gender inequalities, to make sure gender mainstreaming is implemented, and to ensure gender equity is applied in education and policy making. The government is supposed to establish a budget for the commission. ${ }^{18}$ All of these women's organizations have worked together and created networks like the Lebanese Women's Network, the Committee for the Follow Up of Women's Issues, and the Network for the Rights of the Family to achieve gender equality and push forward women's rights as human rights in the campaigns examined. Their work resulted in the state signing and ratifying the Convention on the Elimination of all Forms of Discrimination against Women in 1996.

Women's organizations from 1975 until the end of the civil war in 1990 were forced to step back from their cause to focus on the crises at hand. Just like during the struggle for independence women's movements in many countries had to choose between what seemed to be competing visions. This tug of war from within has stalled the translation of gender equality norms. Over the years with both internal and external interference and conflict activists have had to re-organize and strategize differently. The

\footnotetext{
${ }^{18} \mathrm{NCLW}$ third periodic report to the Committee on the Elimination of Discrimination Against Women, 22 January 2008
} 
different conflicts over time and space have produced several reactions and when the state was not in operation subsumed by crises and reconstruction politicians were preoccupied and activists had to operate within that context. The conflict during the civil war had a different effect on the woman's movement as opposed to the conflicts that have ensued in the recent years. The reason for this difference is partly because of the nature of the conflicts (the first being a civil war and the second being a political crisis and external intervention), and because of the proliferation of organizations and activity on gender equality in the nineties.

The Lebanese State and CEDAW

Lebanon acceded to the Convention on the Elimination of all forms of Discrimination Against Women on April 16th 1997 with reservations that some describe as against the spirit of the convention. It also has not signed the Optional Protocol to the Convention on Elimination of All Forms of Discrimination Against Women (A/RES/54/4) passed in October of 1999 with 95 parties to date.

The reservations applied to the convention on April 16th 1997 include article 9 (2) in regards to woman's equal status in nationality laws, and article 16 (1) (c), (d), (f), and $(\mathrm{g})$ all which refer to the equal status of women in marriage and family laws. In addition the Government of Lebanon considers that it is not bound by paragraph 1 as per paragraph 2 of article 29 , effectively eliminating any provision for other states to mount 
claims of violation against the Lebanese state. ${ }^{19}$ These reservations are a major challenge to combating violence against women. However, increased calls to consider gender equality issues and for cooperation in matters like violence against women have pushed the state to bring about both social and institutional change on the issue.

In preparation for the Beijing Fourth World Conference on Women the wife of the Lebanese President established a National Committee for the Follow Up of Women's Issues to develop a national strategy and plan for participation in the conference. This committee gave way to a formal governmental body, called the National Commission for Lebanese Women (NCLW). ${ }^{20}$ The NCLW was founded in January 2006 as a result of the Beijing conference's global call for the establishment of national institutions for the advancement of gender equality. Established by the Lebanese Council of Ministers the Commission stands at the highest level of government with a broad mandate that includes but is not limited to legislative amendment, advocacy, education, and policy making. The NCLW is the leading governmental body in charge of monitoring that gender mainstreaming and equality are advanced and the Beijing recommendations are implemented. A portion of the public budget was to be allocated for these purposes. ${ }^{21}$ Evidence of the State's attention to the importance of various forms of violence against women can be found in projects and publications initiated and developed by state

\footnotetext{
${ }^{19}$ The Office of the High Commissioner for Human Rights page on the Convention on the Elimination of All Forms of Discrimination Against Women. http://www2.ohchr.org/english/bodies/ratification/8.htm accessed November 12th 2008

${ }^{20}$ Interview 13.

${ }^{21}$ NCLW third periodic report to the Committee on the Elimination of Discrimination Against Women, 22 January 2008
} 
institutions as well as the collaboration of state representatives on projects with women's organizations. ${ }^{22}$ The NCLW has established a national strategy for the advancement of women's equality and officially represents the state in front of the UN Committee on the Elimination of Discrimination Against Women. With the cooperation of local NGOs the NCLW prepares the regular reports on the progress of the state of Lebanon's implementation of the convention. NCLW has submitted three reports to the committee since the state's ratification of the convention.

The Committee on the Elimination of Discrimination Against Women has identified several areas in need of reform in order to bring Lebanon in line with the spirit and ideal of the convention. According to the third CEDAW report prepared by the National Commission from Lebanese Women (NCLW), "The Lebanese legislature has not provided a specific definition of the term "discrimination against women", and that they are still working on addressing issues of gender inequality existent as a result of the reservations made by Lebanon to the convention. However, the report reminds the committee that the reason for the reservations is tied to Lebanon's constitutional consociational make up that permits "legislative and judicial pluralism in the area of

\footnotetext{
${ }^{22}$ Ministry of Social Affairs (MOSA) and Lebanese Council to Resist Violence Against Women (LCRVAW) Publication 2005. The Directory of the Meetings Concerned With the Enlightenment Program on the subject of the prevention of violence within the family from the "Guide Book for Training Sessions Involving Prevention Against Domestic Violence." And KAFA: Enough Violence And Exploitation has several state representatives collaborating on their draft law for a family violence law
} 
personal status codes... and that this subject is extremely sensitive and linked to the broader social and political situation in the country."23

The laws that have been identified as discriminatory by the Lebanese Women's Network and the Committee on the Elimination of All Forms of Discrimination against Women include articles in the penal code on adultery (487,488-489), rape, abuse, and impudence (503-504-505-506-513-515-627-753-522), and crimes of honor (562). In articles 487-489 the law makes it more acceptable for men to be adulterers than women. In cases of adultery women that are found guilty are sentenced to more time than men who are convicted of the same crime. In Articles 503-506 relating to rape the penal code allows for the state not to prosecute in cases where the accused has agreed to marry the victim. The other problem with the rape articles is the exclusion of marital rape. This blatant omission fortifies the notion that a husband is entitled to violating the wife's bodily integrity. This notion is a point of contention in current discussions on the preparation for a family violence draft law, where the debate revolves around how and if the draft law can address marital rape. ${ }^{24}$

These legal shortcomings may violate the amended Lebanese constitution of 1990, which in its preamble clearly defines the state's commitment and responsibility to

\footnotetext{
${ }^{23}$ For more information on the comments made by both the committee on the elimination of discrimination against women and the periodic reports submitted by the state of Lebanon look at http://www.nclw.org.lb/activity_detail-1.cfm last accessed February 3rd, 2009

${ }^{24}$ For more information about the campaign and the obstacles of defining marital rape see http://protect.kafa.org.lb/?q=faqs, and Lamia Rustum Shehadeh, "The Legal Status of Married Women in Lebanon", International Journal of Middle East Studies, 30, no. 4 (Nov. 1998), 501519 and Lamia Rustum Shehadeh, "Coverture in Lebanon", Feminist Review, 76, (2004), p.8399.
} 
gender equality through its upholding of the international agreements and conventions as more binding than national laws. In one of my interviews, a prominent lawyer and activist who has worked on Lebanon's constitutional responsibilities towards women for many years repeatedly emphasized the construction of the constitution and the responsibility of judges to defer to international conventions over internal laws when dealing with pre-existing legislation.25 As far as new legislation is concerned it must not conflict with or contradict international commitments.

The NCLW and the Ministry of Social Affairs have been proactive in the battle against violence by developing and collaborating in the campaigns launched by women's organizations in Lebanon. The state of Lebanon out of its duty to respond to international agreements and criticism has participated in the campaign to eliminate violence against women; however it has not really gone against the grain of a patriarchal social structure that is cemented by its law.

\section{Chapter Outline}

The following chapters develop evidence of the intertwining of civil conflict, political instability, confessional structures, and the state with the translation of global gender equality norms. Chapter two provides a review of the pertinent literature on the global gender equality regime and the norms that it has generated, the women's movement to establish that women's rights are human rights, and the debate on the universality of human rights with the promulgation of the Middle East women's movement. It develops a framework to investigate the translation of gender equality norms in conjunction with

\footnotetext{
${ }^{25}$ Interview 19
} 
the filters and structures that become operative in the process of translation. I examine three established global gender equality norms: combating violence against women, the right to gender equality in personal status codes, and the right to gender equality in citizenship and nationality.

Campaigns to establish these norms are taken up in three subsequent chapters. Chapter three examines the campaigns on combating violence against women and identifies that the translation takes place against the social filters of family honor and family cohesion. The international structure also becomes visible as a pertinent marker in this process in that the activists are confronted by their own subject position in relation to Western positions on the norm.

Chapter four studies the campaigns targeting gender equality in family and marriage laws. This chapter introduces three new filters: the confessional political filter, the "in line with the divine" filter, and a geopolitical filter. It again makes visible international structure, this time in the form of a discourse that postulates a clash of civilizations, which maps onto confessional communities and activates an argument vying for the synergy of religion and universality. Feminist agents' identities and interests also play a role in the translation of these filters and structure.

Chapter five is about translating gender equality in nationality reform campaigns. These campaigns again activate the confessional political filter, and in addition produce a family cohesion filter, and a culture of belonging filter. The translation of the equal nationality norm works against a state and international structure that is defined by the Palestinian question and regional geopolitics. In the conclusion (chapter 6) I provide a 
comparative analysis of the campaigns and the processes of norm translation that they exemplify. I suggest some generalizations and identify topics for further research. 


\section{$\underline{\text { Chapter } 2}$}

\section{Translating Gender Equality Norms: Filters, Translations, and Structures}

This research explores two questions: First, how are universal women's rights norms translated in the complex socio political context of Lebanon? Second, what are the mechanisms at play in the process of norm implementation?

Women's rights campaigns play a central role in the process of norm translation. I have chosen three case studies of campaigns that have mobilized women across Lebanon. The campaigns have formed around the three main issue areas of concern for women in the country: (1) ending all forms of violence against women (2) claiming equal citizenship and women's right to nationality, and (3) revisiting Lebanon's personal status codes to promote equal rights of women. A comparison of Lebanese feminist campaigns will show how established international gender equality norms go through a process of translation as they filter through social, state, and international structures in Lebanon. The work focuses on a process of norm diffusion that is embedded in a causal mechanism identified in the theoretical framework.

This chapter embeds my research in existing literature and develops a theoretical framework. I will first outline the emergence of a global gender equality regime and identify its norms. The second part will review the literature on norm implementation in international relations and social movement theory. The third section will discuss the process of translation and develop a framework for examining the diffusion of international norms in local contexts. 
Global Gender Equality Regime: Establishing the Regime

Nuket Kardam has argued that a global gender equality regime exists. She identifies this regime based on a widely accepted definition of an international regime offered by Krasner as "implicit or explicit principles, norms, rules, and decision making procedures around which actors' expectations converge in a given area of international relations". ${ }^{26}$ The two principles that undergird the gender equality regime include nondiscrimination (one of the fundamental universal human rights principles), and the principle of pushing for equality between sexes. The norms and rules are set by the conventions, treaties, and declarations, most importantly the Convention to Eliminate all Forms of Discrimination Against Women (CEDAW) ${ }^{27}$ The decision making procedures include the monitoring mechanisms that are established by the Division for the Advancement of Women and the UN High Commissioner for Human Rights, the Commission on the Status of Women and the Special Rapporteur on Violence Against Women, its Causes and Consequences. In this work I am particularly interested in the norms outlined by CEDAW and found on the agendas of the UN global women's conferences. These are the norms that women's rights campaigns in Lebanon cite most extensively. What must also be qualified is the fact that in the cases of personal status codes, the nationality law, and violence against women children's rights specifically and

${ }^{26}$ Kardam, Nuket "The Emerging Global Gender Equality Regime from Neoliberal and Constructivist Perspectives in International Relations", International Feminist Journal of Politics, Vol. 6, No.1, 85- 109

${ }^{27}$ It is important to state that there are several conventions and their protocols that are either directly tied to gender equality and non-discrimination principle or that make up the spirit of the convention. 
family rights broadly are used to show that gender inequality has severe repercussions not limited to women. ${ }^{28}$ The norms in question govern gender equality in all matters relating to family, to nationality rights, and the international norm to eliminate violence against women.

\section{Violence against Women}

The norm to combat violence against women has gained special and separate attention in the international gender equality regime. The women's movement over the years has helped spawn this norm, driving violence from behind closed doors and making it a public concern that affects society as a whole. Thomas Risse and Kathryn Sikkink suggest that principled ideas become norms when there is a transformation from "a belief of rights and wrongs to collective expectations about proper behavior for a given identity" ${ }^{29}$ Using violence against women as one of her two case studies Jutta Joachim traces its evolution on the international scene and on the UN agenda, emphasizing, in particular, the importance of framing an issue. As she explains, framing involves the identification of the problem, the outlining of a solution, and making the issue one that is politically motivating to all parties concerned. The first time the issue was defined was at the International Tribunal on Crimes Against Women held in Brussels, 1976. Although, flawed and controversial the Tribunal paved the way for, among other things, the

\footnotetext{
${ }^{28}$ Take a look at the following project description on Lebanese Women Rights and the Nationality Law for a confirmation of the ties between women, children and the family at large http://www.undp.org.lb/ProjectFactSheet/ViewDocument.cfm

${ }^{29}$ For more on this definition of norms review edited works of Thomas Risse-Kappen, Steve C. Roppe, and Kathryn Sikkink, The Power of Human Rights: International Norms and Domestic Change, (Cambridge: Cambridge University Press, 1999),7
} 
development of international networks outside of formalized structures like the UN Women's Conference in Mexico City.

At various junctures since the 1975 Mexico City Conference the women's movement, while divided on which issues should take precedence, was not divided when it came to violence against women. No one could argue with its pervasiveness or that this violence is one that "transcends the bounds of geography, race, class and religion to touch virtually every community, in virtually every corner of the globe". ${ }^{30}$ The issues on the agenda of the Nairobi conference in 1985 were development, equality, and peace. What governments stressed was that violence against women was a major impediment to the achievement of those goals. After Nairobi organizations such as the Ford Foundation extensively funded field research with a narrowing focus on violence against women. According to Joachim the downside to the increased attention was that it resulted in limiting the definition to domestic violence. However, having defined the problem, the next step in the movement was to look for solutions. This included developing group meetings of experts in 1986 that explored the "causes and consequences" of the problem. What became clear was that the problem needed to be brought out from behind closed doors. The notion of the privacy of the family harbored a deep-seated secret of violence and affected the way this violation of human rights was treated both privately and publicly. While privately violence in the family was shrouded by guilt and shame, publicly it was mishandled by reluctance to interfere and lack of tracking it through poor

\footnotetext{
30 Jeanne Ward et al. GLOBAL: Broken Bodies, Broken Dreams: violence against women exposed, November 2005, UN office in Nairobi, Kenya. OCHA/IRIN Publication, also available online at http://www.irinnews.org/IndepthMain.aspx?IndepthId=59\&ReportId=72831
} 
record keeping. The social and legal system had treated the problem inadequately and with the "aim of maintaining and restoring the family unit". ${ }^{31}$ This discovery led to alternate solutions which included the intervention of the legal system and the criminalization of family violence developed by the expert meetings in 1986.

With the limelight shining globally on the issue of violence against women the 1990s brought about extensive mobilizing and a politicization of the issue. The main struggle for the movement was legitimizing women's rights as human rights, and part of that discourse included bringing out the violence against women issue as one that cannot remain behind closed doors. Defining it as a public ailment received quite a bit of resistance both from outside the movement and within (Bunch 1997). Women's organizations around the world helped place violence against women and the issue of women's rights as a human right squarely on the agenda of the 1993 World Conference on Human Rights in Vienna (Friedman 2003). ${ }^{32}$ Women's organizations framed the issue by mobilizing campaigns and linking the idea of gender based violence to human rights. The "16 days of Activism Against Gender-Based Violence" campaign across states included vigils and tribunals and formalized the event by dedicating November $15^{\text {th }}$ to victims of gender violence. ${ }^{33}$

${ }^{31}$ Joachim, Jutta. "Framing Issues and Seizing Opportunities: The UN, NGOs, and Women's Rights", International Studies Quarterly, v. 47(2003), 257

${ }^{32}$ Friedman, Elizabeth Jay, "Gendering the Agenda: The Impact of the Transnational Women's Rights Movement At the UN Conferences”, Women's Studies International Forum, Vol. 26, No. 4. 313-331, 2003

33 For more information on Gender Based Violence and NGO activism look at http://www.unfpa.org/16days/index.htm, and the Center for Women's Global Leadership, Rutgers 
The UN General Assembly in December of 1993 adopted the Declaration on the Elimination of All Forms of Violence Against Women, the first act to formally define gender based violence. The following year the General Assembly appointed a special rapporteur on violence against women whose main responsibility it is to study the causes and consequences of such violence. ${ }^{34}$ Finally, the Beijing Declaration of 1995 ushered in a shift in orientation and language from women to gender. The Platform of Action outlined twelve areas of concentration to be addressed, one of which included violence against women also referred to as gender based violence.

I suggest that combating violence against women is an established international norm within the global gender equality regime. The 1993 Declaration to Eliminate Violence Against Women was the point of transformation from principled ideas to this norm, and the norm was strengthened by the establishment of the Special Rapporteur on Violence Against Women, including its Causes and Consequences, as well as the development of international law that clearly defined rape as a weapon of war and a crime against humanity. This was reinforced by the sweeping verdicts of the International Criminal Ad Hoc Tribunal of the former Yugoslavia and Rwanda solidifying the position that violence against women is an established international norm.

University, http://www.cwgl.rutgers.edu/16days/home.html, KAFA: Enough Violence and Exploitation http://www.kafa.org.lb/advoc1.html

${ }^{34} \mathrm{http}: / /$ www.unhchr.ch/html/menu2/7/b/women/ 


\section{Personal Status Codes}

International norms that establish the equality of men and women in both society and within the home can be traced back to the Universal Declaration of Human Rights (1948), the International Covenant on Civil and Political Rights (1966), the Convention on the Nationality of Married Women (1957), the Convention on the Consent to Marriage, Minimum Age for Marriage and Registration of Marriages (1962), as well as the Nairobi Looking Forward Strategies for the Advancement of Women. The Convention on the Elimination of all Forms of Discrimination against Women provides the rules and structure for these norms (CEDAW General Recommendation 21, Division of Women's Advancement 1994). It was designed to include member states, such as Lebanon, that relegate family laws to religious communities also known as Personal Status Laws. In the first articles of the Convention on the Elimination of all Forms of Discrimination Against Women it is clearly laid out that state parties must ensure their commitment to gender equality within the constitution. Articles 2 and 16 outline the principles and measures to eliminating discrimination with respect to gender equality in family matters. Because of an increased international recognition of the importance of the family unit in development and stability General Assembly Resolution 44/82 designated 1994 as the International Year of the Family. ${ }^{35}$ In response to the calls asking for human rights committees to emphasize their commitment to gender equality norms in family and marriage made by Resolution 44/82 the Committee on the Elimination of Discrimination Against Women that year issued its recommendation 21, which focused

35 For details on what guided the General Assembly to announce the International Year of the Family go to http://www.un.org/documents/ga/res/44/a44r082.htm 
on the articles within the convention that directs states how to eliminate gender inequality norms in family and marriage. Gender equality norms on family law have become one of the fundamental norms of the global gender equality regime with established principles, rules, and decision making structures.

\section{Nationality Rights}

International gender equality norms on nationality and citizenship are a part of the gender equality regime by the evidence provided in the link between principles, norms, decision-making structures on the given issue. The League of Nations first broached the subject of nationality with the Hague Conference of 1930 that studied the conflicting laws of nationality. While the sovereign state has the final say on who is a national, the Hague Convention of 1930 does reaffirm that states must not contradict or act in violation of its commitment to conventions or treaties signed. The Convention on Certain Questions Relating to the Conflict of Nationality Laws outlines the rules and consequences of the loss and acquisition of the nationality of women upon marriage. Several national laws in order to eliminate dual nationality within households had women upon marriage to foreigners losing their nationality and acquiring that of their husbands'. These laws inherently relegated them to second class citizenship and confined them to the private sphere. The Hague conference disappointed United States feminists as it failed to preserve their equality within the household.$^{36}$ Reversing this trend was first broached at the seventh international conference of American states in 1933, which signed a

\footnotetext{
${ }^{36}$ Bredbenner, Candice L. A Nationality of Her Own: Women, Marriage, and the Law of Citizenship. Berkeley and London: University of California Press, 1998
} 
convention on the nationality of women affirming "that no distinction shall be made on the basis of sex as regards to nationality". ${ }^{37}$ A similar principle appeared at the international level only twenty-five years later with the UN Convention on the Nationality of Married Women (1957). CEDAW in 1979 reaffirmed the global commitment to the principle of equality between men and women where the rights to possess, maintain, and pass on nationality are concerned. The principles of eliminating discrimination against women discussed are part of what Kardam defined as the “emerging global gender equality regime". Gender equality norms on the nationality of women have been established beginning with the convention on the nationality of married women that went into effect in 1958 and with 72 contracting members to date. The Convention on the Elimination of all Forms of Discrimination against Women further cascaded this norm as part of the regime with its article 9 on the rights to nationality of women.

In the following section, I probe how the regime is translated to national and local levels by reviewing the existing work on norm implementation and introducing the framework that this work will apply.

Translating International Norms: Models in IR and Social Movement Theories

For international norms to become a matter of practice at the local level, they do not simply get implemented or diffused, but they go through a process of translation. Literature from international relations and on social movements has developed models that trace the implementation of norms assuming the norms are static in nature and do not

${ }^{37} \mathrm{http}: / /$ avalon.law.yale.edu/20th_century/intam02.asp 
change in the process. ${ }^{38}$ They imagine that the end stage of implementation is faithful compliance, For example the "spiral model" examines the stages a norm must go through before it is internalized. The norm passes through five phases and is considered internalized when a state finally adheres to the norm (Risse and Sikkink, 1999). ${ }^{39}$ Throughout these stages the norm is imagined to stay the same. Similarly, Finnemore and Sikkink's model of a "norm's life cycle" traces the norm from its emergence, to when it cascades through to its internalization, taking into account norm entrepreneurs and their participation in norm diffusion. ${ }^{40}$ Again, the norm is imagined to stay the same throughout. Keck and Sikkink propose a boomerang pattern model that describes the role of transnational advocacy networks in the implementation of a norm. They contend that when local civil society organizations advocating for the implementation of a norm find themselves limited because of opposition from the state they seek reinforcement from transnational actors. This reinforcement strengthens their position and puts pressure on the state to adhere to their demands, thereby creating a boomerang pattern for

\footnotetext{
${ }^{38}$ Finnemore, Martha and Kathryn Sikkink, "International Norm Dynamics and Political Change", International Organizations, Vol. 52, No. 4, 887-917 (Autumn 1998) Keck, Margaret and Kathryn Sikkink. Activists Beyond Borders : Advocacy Networks in International Politics. Ithaca N.Y.: Cornell University Press, 1998. Zwingel, Suzanne. How do international women's rights norms become effective in domestic contexts? An analysis of the Convention on the Elimination of all Forms of Discrimination against Women (CEDAW), Brochum University Dissertation 2005

${ }^{39}$ Thomas Risse-Kappen, Steve C. Roppe, and Kathryn Sikkink, The Power of Human Rights: International Norms and Domestic Change, Cambridge: Cambridge University Press, 1999

${ }^{40}$ Finnemore, Martha and Kathryn Sikkink, "International Norm Dynamics and Political Change”, International Organizations, Vol. 52, No. 4, 887-917 (Autumn 1998)
} 
implementation. ${ }^{41}$ While the models sometimes include agent structure explanations, they largely neglect the role of domestic actors and structures and their impact on norm translation ${ }^{42}$ In contrast, I argue that the local adoption of a norm entails a metamorphosis of the norm resulting from domestic filters and from the intervention of domestic actors. I seek to widen arguments about norm implementation drawing on more recent critical constructivist work of scholars such as Jeffrey Checkel, Andrew Cortell and James Davis Jr, and Susanne Zwingel who have called attention to the domestic factors that impact norm implementation. ${ }^{43} \mathrm{I}$ am interested in understanding the impact an international norm may have in varying local contexts, but also want to show how a norm changes in the process of implementation. ${ }^{44}$

The Cortell and Davis Jr. model for a research agenda on domestic impact is derived from the process of the way international norms are introduced and embedded in the domestic structure of the state. One of the factors they suggest as relevant in the translation of international norms is "cultural match", i.e., to what extent do national and

${ }^{41}$ Keck, Margaret and Kathryn Sikkink. Activists Beyond Borders : Advocacy Networks in International Politics. Ithaca N.Y.: Cornell University Press, 1998.

${ }^{42}$ Zwingel, Suzanne. How do international women's rights norms become effective in domestic contexts? An analysis of the Convention on the Elimination of all Forms of Discrimination against Women (CEDAW), Bochum University Dissertation 2005

${ }^{43}$ Checkel, Jeffrey, "Norms, Institutions, and National Identity in Contemporary Europe" International Studies Quarterly, Vol. 43, No. 1 (March 1999), pp. 83-114; Cortell, Andrew P and James W. Davis Jr., "Understanding the Domestic Impact of International Norms: A Research Agenda" International Studies Review, Vol. 2, No. 1, (Spring 2000), pp. 65-87; Zwingel, Suzanne. How do international women's rights norms become effective in domestic contexts? An analysis of the Convention on the Elimination of all Forms of Discrimination against Women (CEDAW), Bochum University Dissertation 2005

44 Checkel, Jeffrey, "Norms, Institutions, and National Identity in Contemporary Europe" International Studies Quarterly, Vol. 43, No. 1 (March 1999), pp. 83-114 
international understandings coincide ${ }^{45}$ Checkel stresses that factors within different domestic contexts can account for the level of legitimacy that an international norm can acquire at implementation, while Zwingel analyzes the processes and actors involved in the implementation of gender equity norms via the Convention on the Elimination of all Forms of Discrimination against Women.

Translating International Norms: A Framework

Following Checkel, Zwingel, Cortell and Davis, Jr. and contrary to most existing theorizations of norm implementation, I suggest a more process-oriented understanding of norm diffusion, one that involves filtration and translation mechanisms and that shows what happens to an international norm during its transition phases. Translation includes the literal language translated but also includes a translation that involves dialogues around the issue that bring it in line with domestic sensibilities. I argue that translation entails the activation of filters. Filters represent particular constellations of arguments in a situated context. They bring together elements of domestic social and political structure with an international discourse and the arguments and framings of political agents, including feminist NGOs. Translation and the presence of a filter do not imply that an international norm cannot be implemented at the national level, but that what takes place in the process of implementation is not a fixed and top-down process of transfer. The filters identified in the campaigns reflect the process of translation which the international norm undergoes as it reaches the domestic context. This process at times requires a

45 Cortell, Andrew P and James W. Davis Jr., "Understanding the Domestic Impact of International Norms: A Research Agenda" International Studies Review, Vol. 2, No. 1, (Spring 2000) 
change in the understanding of the norm within the specific domestic context (see figure $1)$.

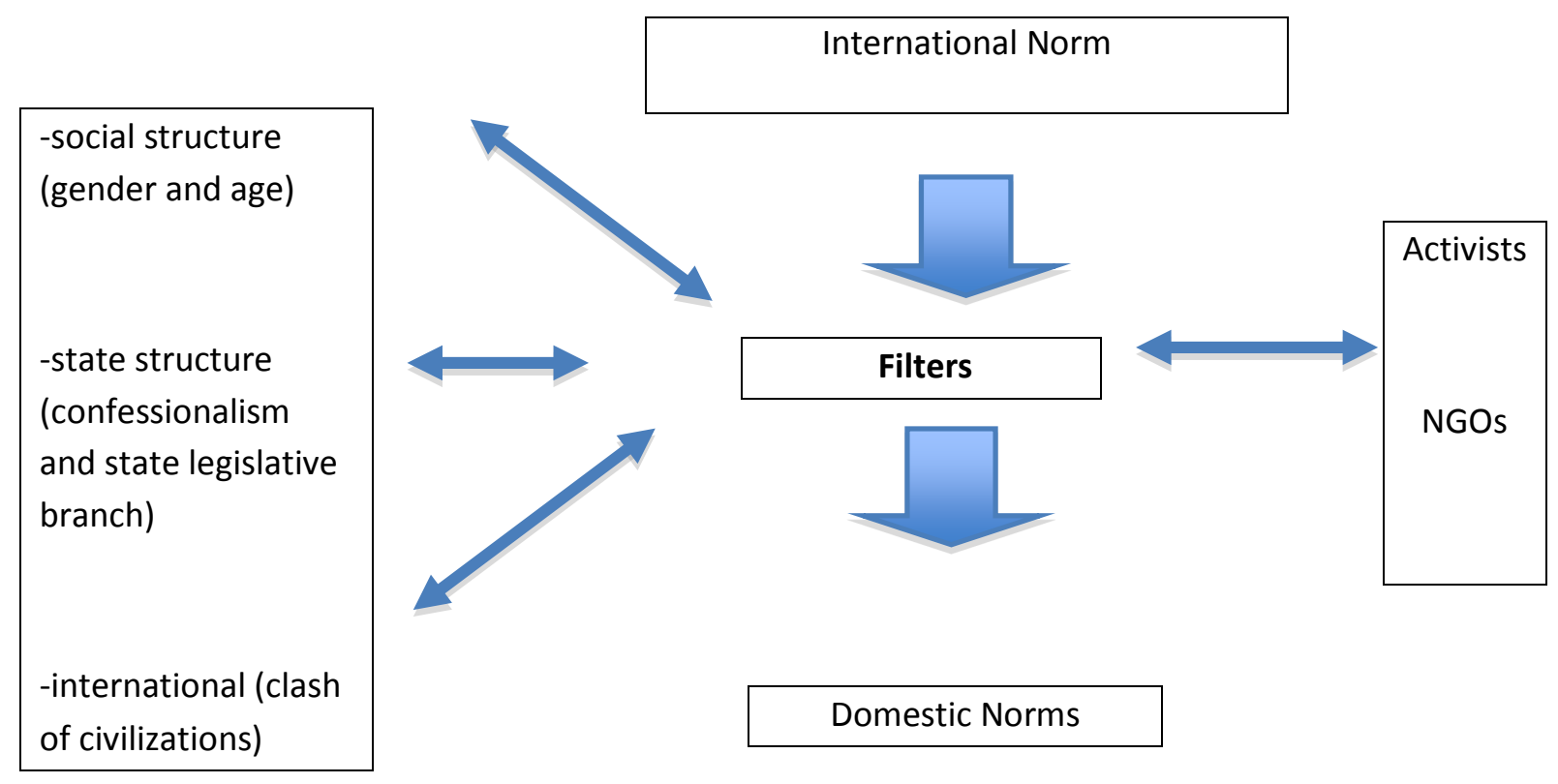

Note: Fat arrows signify process of translation.

As constellations of arguments, filters reflect domestic structures as well as the strategies of agents. By agents I refer to activists, academics, and state representatives. They play a key role in translating international norms, but also put forward arguments that define intervening filters. Some are both agents of the state and also active in campaigns. Indeed, the state itself becomes an active member in all the campaigns through its commitment to the Beijing Action Plan and its establishment of the Lebanese Women's National Commission by decree 13 of the Council of Ministers to follow up on 
the issues outlined by the Fourth Women's World Conference. Feminist agents act as carriers of international norms. They are able to break through solidified structures by reconstructing the norm and providing a translation that is acceptable. They are able to travel back and forth between the different domestic and international contexts renegotiating the norm and thus contributing to the construction of diverse filters.

Agents are embedded in structures, and structures constrain what they are able to do and how they argue. Accordingly, structures influence the kinds of filters that agents produce as they argue for the implementation of gender equality norms. The structures identified in the campaigns examined include state, social and international structures. I will discuss each of these in more detail.

\section{State Structure}

The state structure, which includes government legislative and executive branches also consists of the confessionalist system that characterizes Lebanon's institutions of government and suffuses Lebanese policy-making. While established as a solution to communal conflict, it also has fueled the continuation of such conflict including civil war. The pluralist character of the Lebanese people has proven to be quite a challenge for reformists especially considering its consociational democratic structure that can be described as a complex power sharing system (Taras and Gangulay, 2007). ${ }^{46}$ Lebanon is

\footnotetext{
${ }^{46}$ For more on consociational democracies and their relation to cooperation and stability look at the work of Arent Liphjart who explains a consociational system is established to respect and include multiple ethnic and religious communities. This will produce a more stable government and help create an atmosphere conducive for cooperation and coordination amongst political leaders by including proportional representation within government institutions.
} 
a parliamentary republic, with a unicameral National Assembly composed of 128 deputy members elected by the people every four years. Another key element of the state structure is the legal system. All attempts at legal reform directly related to crime that occurs within the public sphere fall within the purview of the Lebanese Penal Code and the legislative branch. Lebanon's Penal Code is inherited primarily from the period of the French Mandate prior to independence; also included in the existing legislation is the legacy of the Ottoman Empire, which ruled the area for over three centuries. The Ottoman system of governance delegates family law to the confessional groups. As a result, and as outlined in the introduction, the multi-confessional Lebanese state has no secular civil law system, but up to fifteen systems of confessional law. Even though there are differences, all of the confessional laws were drawn from a general law that can be traced back to the Ottoman Law of Family Rights of $1917 .^{47}$

\section{Social Structure}

Social structures refer to the way Lebanon's society is ordered. For the purposes of my inquiry I am particularly interested in the rules that outline how familial and communal life is ordered. While there are differences across confessional and regional communities in Lebanon, I postulate an overarching common social structure that is rooted in confessionalism and a kinship patriarchal model. Similar in patriarchal context to most Western societies, Lebanon's ordering goes beyond a basic patriarchal structure

\footnotetext{
${ }^{47}$ Lamia Rustum Shehadeh, "The Legal Status of Married Women in Lebanon" International Journal of Middle East Studies, Vol. 30, No. 4 (Nov., 1998), pp. 501-519
} 
to include hierarchies embedded in kin, age, and class ordering that operate simultaneously. ${ }^{48}$ Post-colonial feminists have criticized western scholars on their neglect of considering these other hierarchies also embedded within their societies. ${ }^{49}$

The power in Lebanon's gender relations has been the subject of several studies. Suad Joseph in her work points to the fact that as children grow older even the younger males in the family are treated as those that must protect the older female siblings, giving them the sense that they are able to navigate life better and use more sound judgment than their female counterparts. ${ }^{50}$ From over thirty years of researching conceptions such as patriarchy, relational rights and responsibilities in small Lebanese urban and suburban communities Joseph concludes that children in Lebanon are raised with the understanding that they have rights; however, those rights are only afforded to them through the kinship based relationships they are socialized into. With dozens of examples of the communal socialization of neighborhood children in two communities, Joseph puts it best when she says: "To have rights, the children knew that they had to know who had the resources, skills, and services to offer them rights". ${ }^{51}$ Sisters knew that their behavior is a reflection of their family's honor, while brothers knew that they must watch over their sisters'

\footnotetext{
${ }^{48}$ Joseph, Suad. "Teaching Rights and Responsibilities: Paradoxes of Globalization and Children's Citizenship in Lebanon”, Journal of Social History, v. 38 no. 4 (Summer 2005) p. $1007-26$

${ }^{49}$ Mohanty, Chandra. "Under Western Eyes: Feminist Scholarship and Colonial Discourses" Feminist Review, No. 30, (Autumn 1988): 61-88

50 Joseph, Suad. "Teaching Rights and Responsibilities: Paradoxes of Globalization and Children's Citizenship in Lebanon", Journal of Social History, v. 38 no. 4 (Summer 2005) p. 1007-26

${ }^{51}$ Ibid
} 
behavior, and they both knew that following these rules would allow them access to certain commendations, while disobeying had severe repercussions. Joseph also acknowledges that at some point in this process older women gain access to power over certain males within the family because of the relationship that age plays in this hierarchical prism.

Lebanon's social structure is steeped in an inherited kinship patriarchal based communal system that needs to be understood in the context of translating women's rights norms. Even within the use of language evidence of underlying gender inequalities is evident as will be examined in the campaigns. The social structure activates the constellation of arguments produced. Agents translating women's rights norms are part of the social structure therein being coerced at times by their own subject position. Translating international gender equality norms through social structures can metamorphose the norm at hand.

\section{The International Structure}

For realists in International Relations, international structure is anarchical and characterized by the relative distribution of state capabilities. Samuel Huntington has suggested that this structure changed after the Cold War into one that opposes civilizations. Arguably, the politics of the war on terror have contributed to bringing notions of cultural difference, including religious difference, to the foreground of international politics. Tied up into these politics are suggestions of a fundamental difference between Islam and the West, in particular with regard to understandings of women's rights. This dichotomous discourse did not appear in a vacuum and cannot be 
isolated from its historical and political origins within the domains of colonialism and the 'othering' that has accompanied it. In his examination of the literature on the Orient, Edward Said points out that this literature was written from a position of power rooted in the authors' knowledge of those they write about. He postulates that

There has been so massive and calculatedly aggressive an attack on the contemporary societies of the Arab and Muslim for their backwardness, lack of democracy, and abrogation of women's rights that we simply forget that such notions as modernity, enlightenment, and democracy are by no means simple and agreed upon concepts that one either does or does not find, like Easter eggs in the living room. ${ }^{52}$

In this sense, modernity, democracy, and the universality of human rights constitute what Gramsci would have called an ideological hegemonic proposition, and these concepts cannot go uncontested. International norms and their adaptation to local contexts are not isolated from political discourse and do not appear outside of the geopolitical history that gave birth to them. In order to deconstruct the binaries and dichotomous characters created by opposing poles in the literature on the universal character of human rights we must "re-imagine human rights beyond the geopolitical divide" where images of the savage and the victims of human rights violations exist only in the peripheries and the carriers and promoters of the human rights project are the West. Such a projection of the human rights discourse has resulted in the wariness of those on the receiving end, and many have begun to perceive it to be an imperialist venture. This perception of

52 Edward Said, Orientalism, Vintage Books Edition, New York, NY 1994, preface. For a more elaborate discussion on the portrayal of Arabs and Muslims see Edward Said, Covering Islam: How the media and experts determine how we see the rest of the world, First Vintage Books Edition, New York, NY 1997. For further readings related to the clash of civilizations as a scripted concept and reactions to such a script see Bernard Lewis, Islam and the West, Oxford University Press, Oxford 1994; Khaled Abou El Fadl, The Place of Tolerance in Islam, Beacon Press, Boston, MA 2002; John L. Esposito, Islam: The Straight Path, Oxford University Press, Oxford 1998. 
imposition or invasion of the West does not only result in a rejection of the norms seen to be as imposed or foreign but has had unintended consequences. One such consequence has been the effort of Islamic feminists to find alternate truths from within and reconcile religious understandings with the universal norms as is discussed in the literature below on women's rights in Islam. ${ }^{53}$

In a careful study sensitive to these politics Talal Asad addresses the question of hegemony in human rights standards and the imbalance that is produced as a result. $\mathrm{He}$ explores the deployment of human rights in the discourse of individuals, they way in which it is operationalized in the international system, and its attachment to the moral dialogue that brings violations to light. He relates his research specifically to the literature on the clash of civilizations and the ideas put forth by Said in his work on the relationship between knowledge and power and on the way in which access to knowledge on Islam in the United States is dependent on geopolitics and economic interests. He affirms that those who produce knowledge through a particular discourse are representing their own access to or variation of what is understandable, engaging in what Said would describe as a formation or deformation of truth. ${ }^{54}$

\footnotetext{
${ }^{53}$ Brian Nordeste, "Negotiating the Human Rights Debate: Re-Imagining Human Rights Beyond the Geopolitical Divide", Paterson Review: Journal of International Affairs, V. 6, 2005 and Ed. Joseph A. Buttigieg, Antonio Gramsci: Prison Notebooks V. III, Columbia University Press, New York, 1975

${ }^{54}$ Talal Asad, 2000, “What do Human Rights Do? An Anthropological Enquiry?", Theory and Events, Vol 4, Issue 4, Said Edward, Covering Islam: How the media and experts determine how we see the rest of the world, First Vintage Books Edition, New York, NY 1997
} 
Differing variations of truth can be seen in feminist discourse on the security state after September $11^{\text {th }}$. The debate on liberating the women of Iraq and Afghanistan, as well as the security policies implemented by the state were posited either as a move towards modernity or a reflection of modernity's regression of women's equality by assuming that modernity produces only one way to gender equality. The ideas of liberation and modernization in imperial and colonial endeavors are not a new phenomenon or construction and have been examined by scholars like Cynthia Enloe. In her work on nationalism and masculinity she recounts the discourse related to the civilizing mission of local populations in Algeria and its relation to literally unveiling the colonized. To the European women the act of veiling women and the existence of the harem was representative of seclusion and inferiority. This opposing of one culture against another is a reflection of one's own identity and surroundings. By focusing on the subordination of "others", Western women were able to get away from their own struggles for equality and justice at home. This Orientalist presentation of Islam created a backlash in the Egyptian Islamic women's movements, and in defense of their position and the need to remain loyal to their nationalist movement feminists aligned themselves with their Egyptian male counterparts. This type of alignment did have a counter effect of the privileging of the paternal order but also found Egyptian feminists struggling to politicize from within. ${ }^{55}$ The result could be also what Fatima Mernissi describes in her work on the return to the foundational practices of Islam and the internalizing of the practice of veiling amongst women of Islam. Islamic women embraced the practice of

\footnotetext{
${ }^{55}$ Cynthia Enloe, Bananas, Beaches, and Bases: Making Feminist Sense of International Politics, $2^{\text {nd }}$ edition; Los Angeles: University of California Press, 2000
} 
veiling in an attempt to reclaim their understanding of themselves as they viewed the colonialists as agents robbing them of who they were and what they believed. ${ }^{56}$ Just as colonialism furthered the practice of subjugating the woman to status of dominated the imagery of Islamic and Arab women in need of liberation is serving its purpose and is continuing the discourse on the clash of civilizations within the gender equality framework opposing Islamic tradition to Western modernity. ${ }^{57}$

These suggestions have become embedded within a debate over the universality of human rights. A review of the literature on the universality of human rights as they relate to Islam, feminism, and gender equality in the Middle East helps elucidate the international structure narrative that appears in this work.

International Structure in Human Rights Discourse

The debate on the universality of human rights was countered by a cultural relativist argument made mainly by Muslim leaders and becomes poignantly relevant when it concerns women's rights in the region. The main argument made is that a universal conception of human rights is one that is a Western political conception that

\footnotetext{
${ }^{56}$ Fatima Mernissi 1991. The Veil and the Male Elite: A Feminist Interpretation of Women's Rights in Islam. Tr. Mary Jo Lakeland. Addision-Wesley.

${ }^{57}$ For more on this debate see literature by Iris Marion Young. "The logic of Masculinist Protection: Reflections on the Current Security State". Signs: Journal of Women in Culture and Society 2003, v. 29, no 1, and Julia Adams and Ann Shola Orloff, "Defending Modernity? High Politics, Feminist Anti-Modernism, and the Place of Gender" Politics and Gender 2005 v. 1, eds. Wendy Hesford and Wendy Kozol, Just Advocacy Women's Human Rights, Transnational Feminisms, and the Politics of Representation. Rutgers University Press. New Brunswick, NJ 2005, Ronald Ingelhart and Pippa Norris, "Modernization and Gender Equality: A Response to Adam and Orloff", Politics and Gender v. 1, no. 3, 2005, Ronald Ingelhart and Pippa Norris, "The True Clash of Civilizations", Foreign Policy, March/April 2003
} 
neglects to take into account the cultural context of non-Western countries. ${ }^{58}$ Yash Gai (2000), in his work on cultural relativism, argues that within the context of an East-West debate, the concerns propelled by more pronounced multi-ethnic states are connected to the importance of the role nationalism plays in the construction of a cultural relativist $\mathrm{n}$ argument. $^{59}$ Jack Donnelly (2007) has addressed this debate quite extensively over the years, but his most recent work titled The Relative Universality of Human Rights clearly lays out the strength and weakness of both sides of the argument. He introduces two forms of universality, conceptual and substantive. Conceptual universality as he defines it refers to the very understanding of the term human rights, meaning that by our being human we are born with fundamental rights. At this level these rights are vague and abstract. Substantive universality on the other hand is a more tangible term implying a "particular conception or list of human rights." ${ }^{60}$ Contrary to Donnelly’s emphasis on individual rights Ghai points to relativist arguments in multi-ethnic states. Here human rights are considered a collective community investment rather than an individual quest for equality and liberty. This challenges the understanding of human rights as universal. An argument in favor of universality would suggest that human rights by definition apply to all human beings equally thereby creating an element of individualism. According to Ghai a relativist position would dispute that human rights by nature operate in absence of the reflection of others in society. In other words while there is such a thing as human

\footnotetext{
${ }^{58}$ Claude, Richard Pierre and Burns H. Weston, eds. Human Rights in the World Community: Issues and Action. 2nd ed. ed. Philadelphia: University of Pennsylvania Press, 1992.

${ }^{59}$ Ghai, Yash. "Universalism and Relativism: Human Rights as a Framework for Negotiating Inter-Ethnic Claims." Cardozo Law Review 21, (2000): 1095.

${ }^{60}$ Donnelly, Jack. "The Relative Universality of Human Rights" Human Rights Quarterly 29, no. 2 (2007)
} 
nature that is a given, it is not a constant and is malleable to the operations of a society in its entirety. In this context multi-ethnic societies have always tied women's equality and rights to the broader community and more specifically within the realm of the home where her rights are accompanied by her obligations. The struggle has been to frame the advancement of women's rights where the consequence is not at the expense of the family.

Donnelly elaborates the notions of historical or anthropological universality, and in this context engages with reformist Islamic scholarship. His contention is that human rights have not been practiced around the world throughout much of history. While scholars of Islam try to trace the conception of human rights back to the origins of Islam there is no proof of the teachings of human rights as "equal and inalienable" found in any society throughout history and the world. The first intimation of an understanding of human rights as inalienable and equal individual rights can only be traced back to the seventeenth century. Donnelly supports his contention by referring to the widespread practice of slavery throughout much of history and most civilizations.

Donnelly's intention is to remove any cultural or religious characteristic from universal human rights and to place the emphasis on a structure that was created by a process of modernization where certain ideas and values manifested themselves into a set of accepted rules. "Human rights ideas and practices arose not from any deep Western cultural roots but from social, economic, and political transformations of modernity.” ${ }^{61}$ Within this framework the use of international human rights law can be the benchmark of

${ }^{61}$ Ibid, 287 
a universal idea where different cultures, religions, and societies can find an overlapping consensus beginning with the Universal Declaration of Human Rights and the further established and implemented international human rights treaties. Theoretically this is a sound argument; however when probed further this debate spun off into a third dimension. This debate expanded beyond the universal versus cultural scope both in theory and in practice. Those who oppose the entire dichotomous debate based on universal and cultural relativist claims have chosen to address what they deem the failure of international law to solidify what can be proclaimed as a consensus on human rights law. For example, Sunder (2005) points to the failure of human rights law to engage and incorporate religion as part of its framework. This failure has made room for the legitimization of relativity that falls within the scope of sovereignty, what Madhavi terms as evidence of the "new sovereignty". ${ }^{62}$ Sunder and other scholars like Yash Ghai (2006), and Abdullah An'Naim (2001) probe the relationship that religion has to human rights law and the universalist-culturalist debate and have pointed to the fact that religion per se is not contrary to human rights. ${ }^{63}$ Instead, the problem stems from social and cultural norms that take form as having their roots in religion. According to Weston,

${ }^{62}$ Sunder, Madhavi. "Enlightened Constitutionalism." Connecticut Law Review 37, (2005): 891905.

63 An-Na'im,Abdullahi A. "The Synergy and Interdependence of Religion, Secularism, and Human Rights: Prospects for Islamic Societies" Common Knowledge: 2005 ; Sunder, Madhavi, "Piercing the Veil." In Just Advocacy? : Women's Human Rights, Transnational Feminisms, and the Politics of Representation, edited by Wendy S. Hesford and Wendy Kozol. New Brunswick, N.J.: Rutgers University Press, 2005. Ghai, Yash. "Universalism and Relativism: Human Rights as a Framework for Negotiating Inter-Ethnic Claims." Cardozo Law Review 21, (2000): 1095. 
"Both Western universalism and non-Western specificity are capable of being distorted in such a way as to prevent international application of human rights." ${ }^{64}$

According to Sunder (2005) international law has treated religion as something that cannot be controlled or rationalized and should remain in the private sphere. As a result, religion has been used as a carte blanche for human rights violations that have been clearly outlined as unacceptable since World War II. International law has failed to move with the times and with the process of modernization where even the demand of the people has reframed and readjusted religion, culture, and custom to be more in line with the principles of rationality, equality, and liberty. Sunder links this failure to the enlightenment project, which has served as an impediment to addressing questions of religiosity within law. The enlightenment project is in need of revamping and she sees hints of a path to a new enlightenment in the projects of the transnational Muslim feminist organizations she explores.

Sunder looks to women activists in Muslim communities that are challenging not only old patriarchal structures but current law to achieve just what human rights law has failed to provide for them. They question the current system where one must choose between the right to religious freedom and the right to equality and challenge the notion that in order to achieve gender equality one must give up ones religious and cultural identity. Similarly, "subaltern studies" have sought to fill the void left by international legal theory. Scholars in this tradition look at how individuals "negotiate universal ideas

\footnotetext{
${ }^{64}$ Claude, Richard Pierre and Burns H. Weston, eds. Human Rights in the World Community: Issues and Action. 2nd ed. ed. Philadelphia: University of Pennsylvania Press, 1992.
} 
about law, justice, and rights with their continuing commitment to religion and culture". ${ }^{65}$ Sunder uses case studies of Women Living Under Muslim Law strategies and Human Rights Training Manuals, in order to provide us with an alternative formula to combine the rights to both religion and equality. One must not be limited to either fundamentalist or secularist paths.

In an argument along the same lines Abdullahi An-Na'im (2000) suggests that the notion of universal human rights and the relative character of religion are not inherently opposed. He argues that religion is fundamentally interconnected with law. As a community we accept the values of human rights because these values and standards are in line with what we embrace as our moral understanding guided by faith and religious convictions. In other words An-Na'im finds the relationship between religion and human rights law to be one of mutual accommodation and synergy as opposed to one that is antagonistic in nature. The relationship must be understood in the context of global and local social, economic, and political factors. He elaborates on this idea in other works (An-Na'im, 2004) that explore the "interdependence of religion, secularism, and human rights" again by proposing that one cannot come to a consensus on universal human rights norms without a dialogue between various religious communities internal to a state.

An'Naim revisits the concepts of secularism, religion, and human rights in order to challenge the idea that these phenomena are incompatible. He creates a framework

65 Sunder, Madhavi. "Piercing the Veil." In Just Advocacy? : Women's Human Rights, Transnational Feminisms, and the Politics of Representation, edited by Wendy S. Hesford and Wendy Kozol. New Brunswick, N.J.: Rutgers University Press, 2005. pp.271 
showing the interdependence of the three paradigms centered on the role of human agency. His framework shows the multiple ways in which human rights and religion, secularism and human rights, and secularism and religion need each other.

In sum, the international law literature reveals a contestation over rules on human rights, pitting Western universalism against relativism and religion. It has probed the reformulation of universal human rights, discussed the mutual dependence of human rights, secularism, and religion, while also pointing to the importance of dialogue between communities. The literature points to the absence of an engagement with religion in international law and to the need for a progressive analysis of the interdependence of the two not through abstract analysis, but by probing social activism. A thorough challenge to Western secularism and universalism, the new understanding of human rights at once confirms and questions notions of a clash that characterize contemporary international structures.

International Structures and Women's Rights Discourse

The literature on women, human rights, and religion in the Middle East has teased out several misconceptions in the Western portrayal of women in the Middle East, and has discussed whether women's rights are inherently antithetical to Middle East culture and society. It has asked: What is Arab feminism? Where does Islamic feminism fit? While $9 / 11$ generated broad societal interest in questions of feminism and Islam, mostly in contexts that revolve around questions of fear and danger, academic debates 
have been ongoing since the 1990s ${ }^{66}$ These debates have revolved around the binary opposition of secular and religious and the rejection of the notion that feminism must be secular. Margot Badran, Islamic scholar and feminist in an interview reflects on the debate on Islam and feminism as one of monumental importance because it explores "a feminist hermeneutics of the Qur'an" and elucidates its gender neutral intentions. ${ }^{67}$ It provides the grounds for Muslim women to strive for gender equality and social justice based on the writings of the Qur'an. For Badran as well as Amina Wadud who has explored and redrawn the boundaries of Islamic feminism this is a step closer to a universal understanding of feminism. Wadud in her work on rediscovering Islam and its relation to gender developed what she called a "female centered exegesis of Islam" which provided the foundation for Islamic feminists' anti-patriarchal reading of the text and the relationship they build through their engagement with their faith. She calls for a reformist engagement of Islamic leaders to adjust to the context of today's world. ${ }^{68}$ This literature cannot be examined without first addressing those that have called into question Islamic feminists and their relation to Western thought. In an interview with Ziba Mir Hosseini an Islamic feminist anthropologist from Iran now in London points to a gap between Islamic feminists and the female madrasas (Islamic seminaries) that have remained on the periphery of modernity as brought to them by colonialists. This gap prevents the empowerment of Islamic feminism on the ground and also leaves Islamic

\footnotetext{
${ }^{66}$ Basarudin, Azza. "Redefining Feminism/s, Re-Imagining Faith? Margot Badran on Islamic Feminism." Al-Raida XXI, no. 109-110 (Spring/Summer 2005)

${ }^{67}$ Ibid, 58

${ }^{68}$ Amina Wadud, 1999. Qur'an and Woman: Rereading the Sacred Text from a Woman's Perspective, 2nd Edition. Oxford: Oxford University Press.
} 
feminists open to accusations of being just tools of Western projects. She speaks of those activists and non-governmental organizations as apologetic or reactive agents in search of defending assaults launched against their religious identity, while others might truly be speaking from positions of faith. ${ }^{69}$

It is important to understand how different feminists have reacted to what is seen as a western military and cultural invasion and how that reaction relates to their continued belief in the universality of human rights for women. One example is the Islamic feminist demand for a re-reading of the Qur'an discussed above, a progressive interpretation of Islam that according to Moghadam embraces the push for progress through gender equality and women's rights. ${ }^{70}$ But there is another brand of feminism that suggests we need to re-conceptualize our definition of women's agency as more than resistance. Saba Mahmood (2005) critiques certain concepts of the liberal secular movement such as autonomy (the author seeks to redefine autonomy not based on masculinist assumptions), self-realization, and liberty. She argues that Orientalists have denigrated those who embrace piousness and obedience; but members of this movement have effected social change without giving up their faith or identity. They have effected change from within. Activists and other agents are taking this position and bestowing

${ }^{69}$ Ziba Mir Hosseini, Understanding Islamic Feminism: Interview with Ziba Mir Hosseini, Association For Women's Rights in Development, Madrasa Reforms in India, February 24, 2010 http://www.awid.org/Issues-and-Analysis/Library/Understanding-Islamic-Feminism-Interviewwith-Ziba-Mir-Hosseini

${ }^{70}$ Moghadam, Valentine M. Towards Gender Equality in the Arab/Middle East Region: Islam, Culture, and Feminist ActivismHuman Development Report Office, UnitedNationsDevelopmentProgramme, 2004, http://hdr.undp.org/docs/publications/background_papers/2004/HDR2004_Valentine_Moghadam .pdf. 
upon their community the rights afforded within the confines of their religion to women in family law. ${ }^{71}$ This position resonates with Sunder's introduction of an alternative strategy to the right to equality and religiosity. One does not need to equate all fundamentalist Islamist movements with extremism, fanaticism, and radicalism. These are terms that are often conflated and misused in the literature on Islam and Islamic movements.

The debate on Islam and feminism as it was initially formulated revolved around the compatibility of both terms. According to Badran there are those who view Islamic feminism as an oxymoron and question the use of the term feminism, its affiliation with western values and its status as a symbol of colonialist legacy. ${ }^{72}$ At the same time, those who oppose the political engagement of religion point to the failure of Islamic feminism as witnessed by the post-Islamic revolution gender politics and policies. Thus Mojab (2001:131) argues that "Islamic feminism and its various forms, ranging from fundamentalists to reformists, do not have the potential to be a serious challenge to patriarchy." ${ }^{73}$ She ardently supports the idea that true democratization of gender and social relations is based on a system that involves the "separation of church and state." Based on this understanding she finds the Iranian 'Islamic feminist' project of reform an exercise in patriarchy, because Iranian Islamic feminists are not willing to forego their

${ }^{71}$ Mahmood, Saba. Politics of Piety : The Islamic Revival and the Feminist Subject. Princeton N.J.: Princeton University Press, 2005.

${ }^{72}$ Badran, Margot. "Understanding Islam, Islamism, and Islamic Feminism." Journal of Women's History 13, no. 1 (2001): 47.

${ }^{73}$ Mojab, Shahrzad. "Theorizing the Politics of 'Islamic Feminism'." Feminist Review no. 69, The Realm of the Possible: Middle Eastern Women in Political and Social Spaces (Winter, 2001): 131 
commitment to remain within the tenets of Islam. She challenges Islamic feminists to examine their project based on a western understanding of women's rights, which she considers the true progenitor of women's rights, a product of the struggles for democracy in western societies. ${ }^{74}$ While Islamists may disagree with this claim, it is the western experience that shapes all the debates on Muslim women's rights.

To understand the root of Mojab's argument one must take into consideration that, as Susan Buck-Morss (2003) points out, critical theory is primarily written by secularists who are vehemently opposed to a politicized religious project. ${ }^{75}$ Asma Barlas (2005) considers this as an impediment for Muslims in a global context where those like Sharhzad refuse to engage with or recognize the value of the Islamic feminist contribution to Muslim social and cultural norms. Giving this recognition to a political form of Islam would be infusing Islam with power that secularists have withheld so far simply by ignoring its value and presence. Let's begin by "engaging Islamism on its own terms" as Barlas would say. ${ }^{76}$ "Islamism is not terrorism. It is the politicization of Islam in a postcolonial context, a contemporary discourse of opposition and debate, dealing

\footnotetext{
${ }^{74}$ Mojab, Shahrzad. "Theorizing the Politics of 'Islamic Feminism'." Feminist Review no. 69, The Realm of the Possible: Middle Eastern Women in Political and Social Spaces (Winter, 2001): 124-146.

${ }^{75}$ Buck-Morss, Susan. Thinking Past Terror : Islamism and Critical Theory on the Left. London New York: Verso, 2003: 2

${ }^{76}$ Barlas, Asma. "Globalizing Equality: Muslim Women, Theology, and Feminism." In On Shifting Ground: Muslim Women in the Global Era, edited by Fereshteh Nouraie-Simone. New York: Feminist Press at the City University of New York, 2005. pp.105
} 
with issues of social justice, legitimate power, an ethical life in a way that challenges the hegemony of Western political and cultural norms."

Islamic feminism falls within the boundaries of Islamism as it seeks to address fundamental social justice from within the Qur'anic framework. Barlas (2005) claims that if the Qur'an is read in a liberatory way, it must be understood as an antipatriarchal text. Moghadam agrees: Islamic feminism is a Quran based reformist faction that is made up of Muslim women and Islamic scholars that utilize their language skills and religious knowledge to challenge patriarchal interpretations of the text. They call for progressive and reformist understandings of the Quran that make clear that gender bias was not part of the original teachings of the Prophet and Sunna. Islamic feminists claim that gender inequality and oppression emerge from cultural and social norms passed on through a patriarchal structure that pre-dates Islamic civilization.

As reflected in discourses on human rights, religion, and women's rights, the international structure postulates a dichotomous system that opposes Western secularism, human rights and women's equality to Eastern religion and women's and human rights tied to religion. This international structure becomes active in campaigns translating international gender equality norms. Women's activism in the region has reacted to the international structure by expanding the debate and trying to fuse both sides in a similar way as proposed by Sunder and An-Na'im addressing the realities of current local context of concern in this study.

\footnotetext{
${ }^{77}$ Buck-Morss, Susan. Thinking Past Terror: Islamism and Critical Theory on the Left. London
} New York: Verso, 2003 
The state, social and international structures described become visible in campaigns to implement international gender equality norms. These efforts at implementation result in translations, because structures inform arguments that congeal into filters of translation. For example in the campaigns that address Personal Status Codes the state and international structures become operative when the campaign attempts to address legal reform through state and religious institutions. The social and international structures become operative when the campaign seeks to produce grassroots awareness and engages in advocacy aimed at reconstructing social norms. Structures inform the arguments of agents, producing filters of translation.

Susan Bassnett and Harish Trivedi define translation as something that does not just take place in solitary confinement, undisturbed, and without layers of complexity. "Translation is a highly manipulative activity that involves all kinds of stages in that process of transfer across linguistic and cultural boundaries". ${ }^{78}$ Ana Lowenhaupt Tsing adds to the definition with her conception of a "faithless translation" because her work understands translation as an ongoing negotiation in a process that is not straightforward or systematic. ${ }^{79}$ Translations are faithless because they do not faithfully reproduce the meaning of that which is to be translated. Sneja Gunew argues that through faithless

\footnotetext{
${ }^{78}$ Susan Bassnett and Harish Trivedi, Post-Colonial Translation: Theory and Practice, Translation Studies, Susan Bassnett and Harish Trivedi, eds., NY:Routeledge Publishing, 1999, .2

${ }^{79}$ Ana Lowenhaupt Tsing, Transitions as Translations, Cora Kaplan, Joan Wallach Scott, and Debra Keates eds. Transitions, Environments, Translations, (NY:Routledge Publishing, 1997), $255-58$
} 
translation "something new ... is created in the slippage between languages and texts". ${ }^{80} \mathrm{I}$ use this conception with a broadened understanding that extends beyond language to include various structures and the interests and identities of those involved in the process of norm translation. Feminist agents engage in an initial "faithless translation" because they have their own identities and interests that are deeply intertwined with who they are and where they come from. However this translation is not final and is continuously revisited as feminist agents are confronted by arguments reflecting international, state and social structures. The process of translation is not instantaneous nor is it unidirectional. The international norm at times must go through construction and re-construction through the structure and between agents. You find feminist agents in both the state and social structures and as they navigate their different subject positions they find them bound by a sense of belonging both to their communities and to their nation state. This sense of belonging is what conditions their translation of gender equality norms.

The filters identified in this work are constellations of arguments that are informed by the structures and by the interests and identities of the agents. They are what shape the "faithless translations" and what feminist agents help produce. At times the feminist agents identify the filters and try to push the international norms past them, but there are times when they succumb to what is inherently part of them, as they are products of their environment.

\footnotetext{
${ }^{80}$ Sneja Gunew, "Feminist Cultural Literacy: Translating Differences, Cannibal Options", Ilha do Desterro, Florianopolis, 44(July 2003), 153-180, also available at http://www.periodicos.ufsc.br/index.php/desterro/article/view/7426/6808
} 


\section{Research Design}

The dissertation is a qualitative research project that revolves around the discussion of women's rights in a multi-confessional country. The main question is: How are universal women's rights translated into the socio-political context of Lebanon?

In order to address this question I have chosen to compare three local campaigns that address Lebanese women's rights. Following Keck and Sikkink, I define campaigns as "sets of strategically linked activities in which members of a diffuse principled network (what social movement theorists would call a 'mobilization potential') develop explicit visible ties, and mutually recognized roles in pursuit of a common goal (and generally a common target)." 81 The three campaigns that I have selected focus on (1) ending all forms of violence against women, (2) claiming equal citizenship and women's right to nationality, and (3) revisiting Lebanon's personal status codes.

The violence against women campaign frames the issue as part of the human rights debate which attempts to combat cultural norms with the least resistance possible. The campaign's goal is to raise awareness of the public role that violence against women plays, to eliminate inconsistencies and discriminatory laws in the Lebanese Penal Code, and to provide social services to victims of violence. The campaign has two targets: civil society and the state legal system. There are two main laws in the Lebanese penal code challenged by this campaign. One forgives a rapist if he marries his victim and the other

\footnotetext{
${ }^{81}$ Keck, Margaret and Kathryn Sikkink. Activists Beyond Borders : Advocacy Networks in International Politics. Ithaca N.Y.: Cornell University Press, 1998. pp.6
} 
provides for a more lenient punishment for a man who murder's his wife, daughter, or relative if he has done so in the name of honor.

The second campaign, on Lebanon's personal status codes, seeks to promote women's equal rights in the family. The campaign has a goal to raise awareness of the gender inequalities in family law among the various nineteen sects, and to challenge lawmakers to develop a uniform personal status civil code.

The third campaign on claiming equal citizenship and women's right to nationality, has the goal of eliminating the gender biased nationality law that denies a Lebanese woman the right to pass on her nationality to her husband and children, while at the same time a foreign woman has the right to acquire Lebanese citizenship within a year of marrying a Lebanese man. The target of this campaign is the state legal system. Momentum for this campaign is complicated by internal geopolitical concerns and fears. While the international nationality convention has been around since the middle of the $20^{\text {th }}$ century, the delay in implementation in Lebanon is driven by a fear to upset the national census thereby tipping the scales in representation. This discussion is tied closely to the 400,000 Palestinian refugees residing in Lebanon since 1948.

I have selected activities and projects, which fit into the three campaigns, to be studied and analyzed as part of this project. These activities and projects make visible the processes of norm translation in the context of the state, social and international structures described. In the campaign on violence against women, the projects selected include the following: 
- The Lebanese Women's Network headed by the Lebanese Women Democratic Gathering in collaboration with the Lebanese Women's Council launched a project titled Working Towards the Elimination of Violence Against Women in 2004. The project spans over three cities in Lebanon encouraging victims to come forward and providing them with the legal aid and counseling necessary.

- KAFA Towards the Protection of Women from Family Violence: It works in collaboration with state representatives, non-governmental organizations, and experts to push the international norm of violence against women

- Capacity building on the prevention of domestic violence campaign designed by the Lebanese Council to Resist Violence Against Women (LCRVAW) and funded by the European Commission, UNFPA, and the Ministry of Social Affairs, was directed at preventing family violence (including violence against spouses, children, and the elderly). The project launched in 2004 and concluded in 2005.

In the campaign on equal rights in personal status codes, the projects selected include:

- The Network for the Rights of the Family formed in 2005 launched Campaign 13/15, whose aim is to reform custody laws across confessions and to draft the rules on parental responsibility, still ongoing. 
- Women's Rights to Marriage and Divorce in Islam, which is aimed at empowering women by arming them with the rights provided through a marriage contract according to Sunni Islamic law

- Civil Marriage is a Civil Right, a campaign in pursuit of a secular civil marriage law.

There have been a series of projects launched to address the gender biased nationality laws of Lebanon. They include:

- The Women's Learning Partnership for Rights, Development, and Peace launched a project in 2006 in coordination with other Arab states entitled Claiming Equal Citizenship: The Campaign for Arab Women's Right to Nationality. In Lebanon the Collective for Research and Training on Development-Action (CRTD-A) is working with several local NGOs planning on a case by case basis to challenge the judicial courts using the argument that the laws are violating the constitution. In addition they are drafting a legal document which will be circulated to Ministers and used as a lobbying tool.

- The National Follow-up Committee for Women's Issues launched a new project funded by the US Agency for International Development, $M y$ Nationality is the Right of my Husband and my Children in September 2007 which lead to their funding by the UNDP in 2008 on the project titled Lebanese Women Rights and the Nationality Law. 
Methods

This work is based on a feminist epistemological concern that confronts dualisms and dichotomies such as male/female, reason and rationality versus emotion, West/East. These dichotomies are "false in the way in which they imply opposite, unconnected extremes and consistently devalue the second component." 82 Instead, I seek to understand feminist activism from the inside, taking a feminist standpoint that activists have developed through their campaigns. I seek to develop "feminist knowledge that is grounded in experiences of gendered social life but is also dependent on judgments about the justice of social relationships, on theories of power and on the morality of social investigation". ${ }^{83}$ Another aspect of this work is the post-colonial feminist understanding that takes into consideration questions of race, class, and gender that are all operative simultaneously. ${ }^{84}$

This research used a triangulated method of interviews, participant observation, and textual analysis to connect ideas to experience to reality. ${ }^{85}$ Triangulation allowed me to strengthen my findings and ground the research project in discourses at different sites. Data collection took place in three phases over a period of eighteen months. An

\footnotetext{
${ }^{82}$ Maynard, Mary. Researching Women's Lives from a Feminist Perspective. London Bristol PA: Taylor Francis, 1994. pp. 18

${ }^{83}$ Ramazanoglu, Caroline. Feminist Methodology : Challenges and Choices Sage Publications, 2002.

${ }^{84}$ Mohanty, Chandra. "Under Western Eyes: Feminist Scholarship and Colonial Discourses" Feminist Review, No. 30, (Autumn 1988): 61-88

${ }^{85}$ Ramazanoglu, Caroline. Feminist Methodology : Challenges and Choices Sage Publications, 2002.
} 
exploratory Phase I included background research on organizations, campaigns, and projects around the three main areas of concern, establishing contacts with organizations and academic researchers. The initial contact and nurturing of relationships at the local level paved the way to develop a more active engagement in the second phase of the research. There are over three thousand NGOs in Lebanon that dedicate some effort and funding to women's concerns. The organizations that proved to be most visible and cooperative included: The Lebanese Council for Women, an umbrella non-governmental organization that groups about 170 NGOs, the Union of the Working Women in Lebanon, Lebanese Democratic Women's Gathering, Bahithat (Lebanese Women Researchers), the Lebanese Council to Resist Violence Against Women (LCRVAW), the Arab Permanent Court to Resist Violence Against Women, the Institute for Women's Studies in the Arab World, the Non-Governmental National Committee for the FollowUp of Women's Issues, National Commission for Lebanese Women, and KAFA: Enough Exploitation.

Examining of global communication strategies used to develop the campaigns and projects in question became relevant at this point. I understood the strategies developed through an analysis of the literature found on websites of transnational networks like Femme Mediterraneenes, PeaceWomen of the Women's International League for Peace, Freedom-Lebanon, the Women's Learning Partnership for Rights, Development, and Peace, and the Association for Women's Rights in Development.

Phase II of the research project involved individual open ended taped interviews with lead questions conducted in Arabic, French, or English with members of organizations, 
leaders, academics, activists, and politicians in Lebanon. These interviews enlightened me to the process of translation used in filtering international women's rights norms at the local level. Interviews helped reveal how organizations collaborate and at times clash to achieve equal socio-political rights while navigating a messy and confusing geopolitical atmosphere. More poignantly the open-ended interviews allowed for an honest engagement with women's rights in a multi-confessional setting thereby revealing the rationale, expectations, and commitments to the international norms established by the global gender equality regime. This is also where resistance and complex geopolitical contexts were revealed.

To complement the one- on-one interviews I attended local conferences and observed other campaign activities between February and May 2008. Participant observation helped me get a better understanding of how international norms are translated at the most basic level while agents are communicating between organizations, and the effect of these venues as sites for knowledge dissemination and accommodation.

Phase III of the project began with the transcribing of the interviews. The second and most important part of this phase was the analytical work which was divided into three segments. The first was a systematic analysis of material gathered from various websites where organizations have defined and implemented strategies for projects and campaigns. A common example of such an occurrence is the use of links from one organization to another, or from one campaign to another. The second was an analysis of my transcribed interviews through close reading. I looked at the way certain words and phrases were said, the meaning behind the dialogue, the framing of certain concepts, and how they 
interacted with the global discourse. Finally, I related my findings to observations from participating in campaign and project events.

The comparison of the three campaigns allowed me to identify patterns and variances and develop inferences based on those variances. In other words, it allowed me to identify particular filters at play in different women's rights campaigns and infer hypotheses about the relationship of norm translation and state, social, and international structures. 


\section{Chapter 3}

\section{Campaigns Combating Violence Against Women}

The Beijing Platform for Action, the Declaration to Eliminate Violence Against Women, and the Convention on the Elimination of All Forms of Discrimination Against Women have established international norms for combating violence against women, and countries around the world are applying this international norm within very different national contexts. Nuket Kardam has argued that a global gender equality regime exists at the international level. She identifies this regime based on a widely accepted definition of an international regime offered by Krasner as "implicit or explicit principles, norms, rules, and decision making procedures around which actors' expectations converge in a given area of international relations". ${ }^{86}$ The principles that provide the basis for the gender equality regime include non-discrimination, one of the fundamental universal human rights principles, and the principle of pushing for equality between sexes. The norms and rules are set by the conventions, treaties, and declaration, most importantly the Convention to Eliminate all Forms of Discrimination Against Women. The decision making procedures include the monitoring mechanisms established by the Division for the Advancement of Women and the UN High Commissioner for Human Rights, the Commission on the Status of Women and the Special Rapporteur on Violence Against Women, its Causes and Consequences.

${ }^{86}$ Kardam , Nuket "The Emerging Global Gender Equality Regime from Neoliberal and Constructivist Perspectives in International Relations", International Feminist Journal of Politics, Vol. 6, No.1, 85- 109 
Here I am particularly interested in norms on violence against women. Regime norms, in Nuket Kardam's words, "define the rights and obligations of actors by establishing standards to overcome discrimination." Thomas Risse and Kathryn Sikkink suggest that principled ideas become norms when there is a transformation from "a belief of rights and wrongs to collective expectations about proper behavior for a given identity" ${ }^{87}$ I suggest that combating violence against women is an established international norm within the global regime. The 1993 Declaration to Eliminate Violence Against Women was the point of transformation from principled ideas to this norm, and the norm was strengthened by the establishment of the Special Rapporteur on Violence Against Women, including its Causes and Consequences, as well as the development of international law that clearly defined rape as a weapon of war and a crime against humanity. ${ }^{88}$

Lebanon, a country reeling from civil unrest and characterized by a complex socio-political system based on confessional divisions, is one of the countries that has taken up the battle. This chapter traces what happens to an international norm as it transcends boundaries to be enacted in a local environment. What are the mechanisms at play in the process of norm implementation?

\footnotetext{
${ }^{87}$ Thomas Risse-Kappen, Steve C. Roppe, and Kathryn Sikkink, The Power of Human Rights: International Norms and Domestic Change, Cambridge: Cambridge University Press, 1999

${ }^{88}$ Finnemore, Martha and Kathryn Sikkink, "International Norm Dynamics and Political Change”, International Organizations, Vol. 52, No. 4, 887-917 (Autumn 1998)
} 
I trace the translation of the international norm by exploring Lebanese campaigns on violence against women. In Lebanon violence against women is found within the purview of the state, in society, and in civil confessional legal systems. As in other contexts, it is understood in its various forms both as direct and indirect violence against women. Indirect violence against women refers to discrimination that is found in the laws or the absence of laws where the protection of women is non-existent or insufficient. Direct violence against women includes "corporal violence, moral and psychological violence, voice violence, sexual violence, and economic and financial violence" ${ }^{89}$ First and foremost Lebanon has experienced violence at wide scale through sixteen years of civil war. The issue of violence against women in Lebanon gained momentum after the end of the civil war in the 1990s. There is increasing awareness of its multiple dimensions, including violence in the family and workplace, public social violence committed in crimes, and random acts of violence.

Most activism targets the issue of violence against women within the context of family. Violence against women is a particularly burning issue because of the communal social organization of Lebanon and because of the absence of legal protection for women within the family. There are no accurate statistics on domestic violence in Lebanon; however, studies have shown that the problem is widespread, and estimates suggest that up to thirty percent of homes have experienced some form of domestic violence. ${ }^{90}$ The

${ }^{89}$ Kardam , Nuket "The Emerging Global Gender Equality Regime from Neoliberal and Constructivist Perspectives in International Relations", International Feminist Journal of Politics, Vol. 6, No.1, 85- 109

90 Usta, Jinan, Jo Ann M. Farver, and Nora Pashayan, "Domestic Violence: The Lebanese Experience", Public Health, 121, no. 3, : 2007, pp. 208-219 
state condones violence against women through certain provisions in the penal code. This includes the state's denial of marital rape, and its law that still mitigates penalties for those types of murder commonly referred to as "honor killing," and its willingness to exonerate a rapist on condition that he marry the victim. The debate on the ground is contentious as it seeks to tackle a firmly ingrained social patriarchal structure.

The movement to eradicate violence against women and to recognize it as a problem socially and legally is relatively young. Prior to the emergence of a global gender equality regime that identified the problem of violence against women, Lebanon's activity on this front was limited in scope and to a few social organizations and researchers. Dar Al Amal Association founded in 1970 is an example of an organization that addressed a form of violence against women for years prior to the international movements' push in the mid- to late 1990s. Dar Al Amal considered women and children embroiled in prostitution rings victims of violence against women and tailored their programs to offer rehabilitation and prevention. ${ }^{91}$

More recent campaigns to eliminate violence against women have focused on raising awareness, advocacy, and providing services to victims of violence. The campaigns have struggled to fight the social and legal understanding that family issues and women's issues are a private affair, reflecting a patriarchal social structure that is deeply ingrained and entwined in the fabric of society. While there are only a couple of organizations specialized in dealing with direct violence against women, several

\footnotetext{
${ }^{91}$ See website the Lebanese NGO Forum that provides an overview of women's organizations work on violence against women http://www.lnf.org.lb/windex/brief3.html\#a6
} 
organizations and networks focused on women and human rights issues have broadened their missions to incorporate work on violence against women. The current study traces how women's organizations campaigns on violence against women have evolved in Lebanon.

The first section of this chapter introduces a brief background on Lebanon and the conditions of violence against women including some brief information on the existing campaigns and social conditions. The second section will illustrate how the international norm on combating violence against women has undergone a transformation through the campaigns examined. I identify two mechanisms involved in the process: translation and filters. Clearly laying out how these mechanisms operate in the campaigns examined will take place in the two sections leading up to the conclusion. In the conclusion I will review the process of norm application, how it has changed the norm and what this could mean for future feminist work on norm implementation in international relations and transnational social movement literature.

\section{Campaigns to Eliminate Violence Against Women in Lebanon}

In 1995, a public hearing on violence against women in Beirut, the first of its kind in the Arab world, marked the beginning of the campaign to eliminate violence against women in Lebanon in 1995. This hearing led to the establishment of the Arab Women's Court whose initial coordinator was in Morocco and has now been transferred to Lebanon. The collaborators of the Arab Women's Court in Lebanon are key players in the local launching of the campaigns examined in this section. These campaigns have two facets, one that targets what has previously been identified as direct violence against 
women and another that targets indirect violence. Accordingly, the campaigns encompass a range of activities, including vigils, awareness seminars, legal counsel, psychological counseling, and conferences. The campaigns are a product of collaboration between state representatives or institutions, non-governmental organizations, and international organizations. They provide explicit examples of how the international norm to combat violence against women is filtered through the state and social structures, and also how the translation of the norm sometimes produces a metamorphic change.

There are only a couple of organizations specialized in dealing with situations of direct violence against women in Lebanon. However, there are several organizations that have broadened their mission to incorporate work on violence against women and that at times work in collaboration with either of the two specialized NGOs. While violence against women as explained above is understood and accepted in its various forms, it seems that the focus has been on domestic violence. Campaigns are pushing for laws to combat gender based violence crimes.

The two main organizations whose mission it is to eradicate violence against women are the Lebanese Council to Resist Violence Against Women (LCRVAW) established in 1997, and KAFA: Enough Violence and Exploitation (here on out I will refer to this organization simply as KAFA) founded in 2005.

The main objective and the main challenge of the organizations are to transfer the issue of violence against women from the private to the public sphere, thereby placing the responsibility to address discrimination and violence against women at the feet of the state. Broadly defined by LCRVAW, violence against women is "any act of violence that 
harms women physically, psychologically, economically, or socially." ${ }^{\text {92 }}$ KAFA's broad definition of violence against women encompasses the use of "power and control" and the idea that it is a "chosen action against a woman or girl child simply because of her gender..." and that it "cuts across race, religion, income, class, and culture" and is "deeply imbedded in all cultures, so much so that millions of women consider it a way of life.” KAFA chooses to abide more specifically by the General Assembly's 1993 Declaration on the Elimination of Violence Against Women Articles 1 and 2. Article 1 defines violence against women as "any act of gender-based violence that results in, or is likely to result in, physical, sexual or psychological harm or suffering to women including threats of such acts coercion or arbitrary deprivation of liberty, whether occurring in public or in private life. ", and Article 2 includes the specific list of acts that occur within the family, in the general community, or acts that are condoned by the state. ${ }^{93}$ KAFA also subscribes to Recommendation 19; paragraph 6 of the $11^{\text {th }}$ Session of the CEDAW committee that defines gender based violence and subsumes the definition into the definition of discrimination of the convention. ${ }^{94}$ By linking to this recommendation the organization is reminding the state that although CEDAW does not explicitly define violence against women, the state must understand the declaration to fall within the purview of the convention.

\footnotetext{
${ }^{92}$ See the organizations' web sites for their definition of violence against women at www.lebanesewomen.org and www.kafa.org.lb

${ }^{93}$ For a complete reading of the declaration look at http://www.unhchr.ch/huridocda/huridoca.nsf/(Symbol)/A.RES.48.104.En

${ }^{94}$ For all the recommendations of the committee to eliminate all forms of discrimination against women look at http://www.un.org/womenwatch/daw/cedaw/recommendations/recomm.htm
} 
Women's organizations combating violence against women through organized campaigns have formed the Lebanese Women's Network and the Committee for the Follow-Up of Women's Issues. These two organizations are made up of several women's organizations that have pledged to collaborate in an attempt to amend existing laws that are gender biased and implicitly justify violence against women.

The next section provides a brief overview of three campaigns that have specifically dealt with violence against women with details regarding the participants, the events, and the life span of the campaign. The three campaigns are (a) the national campaign for the elimination of discrimination against women in the penal code, (b) the campaign towards the protection of women from family violence, and (c) capacity building on the prevention of domestic violence.

The national campaign for the elimination of discrimination against women in the penal code was organized by the Lebanese Women's Network (LWN) in 2004 and came to a halt with the closure of parliament in 2007.95 LWN is made up of fourteen registered non-governmental organizations, some of which are umbrella organizations with over a hundred and fifty member organizations, which span across Lebanon's regions and confessions. The campaign's purpose was to amend the gender biased laws in the penal code. As highlighted earlier, these laws dealt with violence against women in the form of rape, abuse, impudence, and the commonly referred to honor crimes.

\footnotetext{
95 After the assassination of Prime Minister Rafik Al-Hariri and the withdrawal of Syria from Lebanon in 2005 political tensions rose and, coupled with a string of political assassinations, the country teetered on the brink of collapse. Two political parties formed, the Majority and the Opposition, part of the parliament walked out in protest, and the state business came to a halt when the opposition boycotted government late 2006 .
} 
According to one of the founders, the vision of LWN was to create a network of women's organizations across confessional groups which are not limited by religiously sensitive issues. The purpose was to provide a context where collaboration could take place without the influence of religious convictions and leaders that could affect the agreed upon task.

KAFA is the principal organizer of the second campaign, the campaign towards the protection of women from family violence. KAFA: Enough Exploitation founded in 2005 works mainly to eliminate the causes and results of violence against women and children supported mainly by the European Union, United Nations Development Fund for Women, and MaMa Cash an international women's fund established in 1983 in the Netherlands. It works in collaboration with state representatives, non-governmental organizations, and experts to push the international norm of violence against women through to the state and social structures. The main goal of the campaign is to translate the norm through legislative action. KAFA: Enough Violence and Exploitation in collaboration with Association Najdeh, YWCA, Judge Johnny Azi, Judge Eskandar, Association of Doctors, Beirut Women's Association of Lawyers, among other experts have drafted a law protecting women from family violence. The plan is not only to change government institutions and departments, but to also re-construct the normative understanding of representatives of government and civil society and encourage their contribution to combating violence against women. The campaign was established following a regional meeting that involved representatives from eleven Arab countries, national, and international NGOs. The meeting, "Legalizing the Protection against 
Family Violence" was organized by KAFA and held on 22-23 July 2006. There is no end date established for this campaign as long as all the goals have not been met. The objectives laid out by the campaign include getting the state to pass a family violence draft law, advocacy of the issue of family violence as a human rights violation, raising awareness of the issue of family violence and its manifestations, and garnering momentum across civil society in order to successfully pass the proposed legislation. KAFA is funded by the European Union, MaMa Cash, and UNIFEM Jordan. ${ }^{96}$

The third campaign, Capacity Building on the Prevention of Domestic Violence, designed by the Lebanese Council to Resist Violence Against Women (LCRVAW) and funded by the European Commission, UNFPA, and the Ministry of Social Affairs, was directed at preventing family violence (including violence against spouses, children, and the elderly). The campaign launched in 2004 and concluded in 2005 and the main target was the state and social structure. The goal was to arm city social workers with an understanding of domestic violence and to make them aware of the common misconceptions around the issue. The campaign also fulfilled one of the recommendations made to governments by the Beijing Platform of Action Plan because it is evidence of collaboration between the state, international, and national organizations in combating violence against women. The campaign meant to inform social workers of the role they are to play and their responsibility in handling cases of domestic violence. On the social front it helped bring out this private matter into the community by having families work together and talk about what usually is left behind closed doors. This

\footnotetext{
${ }^{96}$ The campaign has set up a facebook group and a website designed to be part of the campaign entitled "Towards the Protection of Women from Family Violence. See http://protect.kafa.org.lb/ and http://www.new.facebook.com/group.php?gid=22846255242.
} 
campaign included several projects, one of which was training sessions for social workers on how to identify and deal with domestic violence. The campaign was also supposed to serve as a catalyst for change by proposing solutions and alternatives. On the social scale it held various town awareness raising sessions with a group of families where conceptions were reviewed and participants were asked what those conceptions meant to them. The final publication, a booklet produced in 2005, included an overview of the projects and the definitions and outcomes of family violence with all its misconceptions and consequences. ${ }^{97}$

How have these campaigns translated the international norm to combat violence against women in Lebanon's complex context? What kinds of social filters operated during the campaigns? The following section probes three filters - the culture of violence filter, one involving honor and the other family cohesion.

\section{Filters: Family Honor and Family Cohesion}

As I interviewed several women activists during my fieldwork what became clear are deeply ingrained patriarchal rules and norms embedded both within the family home and within the community. In order to really understand the complexity and depth that surrounds the issue of violence against women I outline these rules that structure the lives of men, women, and children as they emerged from the encounters of the campaigns. The most important point to be made first is that the Lebanese society is ordered by a patriarchal order that is not only characterized by gender relations but also by age and

${ }^{97}$ Lebanese Council to Resist Violence Against Women, "A guidebook for training sessions involving prevention against domestic violence", (2005) Ministry of Social Affairs (MOSA),Beirut Lebanon 
kinship hierarchies. ${ }^{98}$ The order became visible as my interviewees elaborated on their in the campaigns, generating three filters that they needed to work with and against. In their translations, it ultimately modulated the international norm on violence against women.

The social structure in Lebanon makes it extremely challenging to deal with the issue of violence against women. A primary concern, often omitted in discussions of violence against women in other contexts, is the culture of violence developed in the course of a lengthy civil war. My last interview took place in the home of a noted lawyer and activist while at the same time the road to the airport was blocked off by burning tires, Hamra and other parts of Beirut were occupied by opposing political forces that were battling it out with guns and other weapons. The TV was on and we were monitoring the situation closely, our fear was that we were heading into another civil war, and yet she graciously agreed to be distracted by my interview on women's rights.

However, this discussion could not stray very far from the matter at hand. She had begun to partake drafting the law on family violence with KAFA, but decided to remove herself as a member, and offered an explanation as to why.

Let me tell you what the real story is with KAFA and reasons beside the travel issue that made me decline working with them. Because they started to talk about the man and how they should do this to the man and what not, but my sister the question of violence belongs to the community. Today when people are killing each other in the street and nobody is bothered by this and that this could possibly continue and nobody cares... This society is teaching violence, and the lesson is for society as a whole, you cannot solely hold one part of the society

\footnotetext{
${ }^{98}$ Joseph, Suad. "Teaching Rights and Responsibilities: Paradoxes of Globalization and Children's Citizenship in Lebanon”, Journal of Social History, v. 38 no. 4 (Summer 2005) p. 1007-26
} 
responsible for it...And you cannot research it unless the society is united and in agreement. You cannot campaign and talk about violence in a warring society, and talk about holding the man responsible. But there is a context here...Here you can understand that there is outside pressure coming in...Because the understanding of violence in an area of conflict is one thing, and violence in a stable and united area is another. ${ }^{99}$

To this activist the importance of addressing the broader implications and effects of strife were somehow lost in the translations of violence against women in the draft law. Somehow filtering this combat against violence had to address two entangled contexts: conflict and culture. The threat of the communal clashes escalating into a renewed civil war distracts from combating violence against women. Having to confront the different types of violence occurring at the local level forces organizations to prioritize combating violence based on a hierarchy of issues.

The Family Honor Filter

One of my interviewees asked rhetorically "why is it that a man's honor is carried by a woman? And what about the woman's honor why is man not caretaker of hers?"100 This idea is pervasive in both Lebanese families and the communities. As a young teenager in Lebanon my mother, father, and aunt emphasized the importance of what I considered appropriate rules of engagement. If you are walking on the street be careful who you stop and talk to, and if someone honks their horn at you make sure not to turn and look. Your behavior can shame the family. You know how things work over here. The most dominant concern is the one addressed by most activists and academics, and

\footnotetext{
${ }^{99}$ Interview 19

${ }^{100}$ Interview 8.
} 
that is the social and traditional context usually referred to in Arabic as "the mentality of the society (al zuhniyeh)."

This mentality serves as a powerful filter in the campaigns on violence against women, and in particular in those attacking "honor crimes." For one of my interviewees at LCRVAW a major concern was that society views honor crimes as normal because it identifies the male role as one of protector and preserver of a woman's honor. ${ }^{101}$ Indeed, the state supports society in this interpretation and considers honor crimes as "an outcome of a complex triangular interaction" between crime, state, and society that contributes to the reproduction of gender relations in the Middle East. ${ }^{102}$ According to Abu-Odeh, the relation between the state and society is governed by the codification of honor crimes and is used by the state as a way to both "contain the practice of crime, whilst attempting to co-opt the emergence of new subversive sexual types". ${ }^{103}$ Through its laws the state is able to deter murder. But by allowing for lenient punishment in certain cases of honor crimes, it helps control the behavior of women. Society also takes advantage of the loophole created by Article 562, referred to as the honor killing article, by supporting and justifying male control over women. ${ }^{104}$

\footnotetext{
${ }^{101}$ Interview 6.

${ }^{102}$ Lama Abu-Odeh "Crimes of Honor and the Construction of Gender in Arab Societies", Mai Yamani ed., Feminism and Islam: Legal and Literary Perspectives, (NY: New York University Press, (1997),141-194

${ }^{103}$ Ibid

${ }^{104}$ Ibid
} 
The power in Lebanon's gender relations has been the subject of several studies. Suad Joseph in her work points to the fact that as children grow older even the younger males in the family are treated as those that must protect the older female siblings, giving them the sense that they are able to navigate life better and use more sound judgment than their female counterparts. ${ }^{105}$ From over thirty years of researching conceptions such as patriarchy, relational rights and responsibilities in small Lebanese urban and suburban communities Joseph concludes that children in Lebanon are raised with the understanding that they have rights; however, those rights are only afforded to them through the kinship based relationships they are socialized into. With dozens of examples of the communal socialization of neighborhood children in two communities, Joseph puts it best when she says: "To have rights, the children knew that they had to know who had the resources, skills, and services to offer them rights". ${ }^{106}$ Sisters knew that their behavior is a reflection of their family's honor, while brothers knew that they must watch over their sister's behavior, and they both knew that following these rules would allow them access to certain commendations, while disobeying had severe repercussions.

My interviews with campaigners highlighted how language is used to structure gender relations and reproduce the notion of family honor. At KAFA headquarters the conversation began at the receptionist desk as I awaited my interviewee. I mentioned how difficult it was to translate the conception of women's rights from English to Arabic. Her response intrigued me as she made it known that it was not the first time that this problem

${ }^{105}$ Joseph, Suad. "Teaching Rights and Responsibilities: Paradoxes of Globalization and Children's Citizenship in Lebanon", Journal of Social History, v. 38 no. 4 (Summer 2005) p. $1007-26$

${ }^{106}$ Ibid 
was broached in the office. So as my interview began I felt the need to raise the topic again, and immediately without hesitation my Arabic translation of the word woman was corrected.

Well we don't use the colloquial term for women (pronounced mara), we use the standard Arabic (pronounced mar2a with an accent before the-a) ${ }^{107}$ pronunciation because when the former term is used it can have a negative connotation, as if you are not a virgin. They always differentiate between girl and woman, and if you call a young unmarried woman, woman using the colloquial connotation then it is an insult. We always try to get people to use the common standard Arabic because used as such Woman's Right and Obligation resonates more. ${ }^{108}$

Colloquial language reflects underlying gendered inequalities. The translation of gender equality norms runs up against such filters. In the local colloquial context the common term for man is not accompanied by any negative or positive social understanding. However, for women language serves as a constant reminder of the value of their virginity and how it is attached to their honor and the honor of their families. Feminist agents here try to translate international norms of gender equality by literally also translating "woman", i.e., by using the formal standard Arabic language. That choice allows them to diffuse the local negative connotations attached to the word, and secondly to convey the seriousness of the issue of women's rights. I noticed this manipulation of language not only in that specific interview (although the rest of that interview was conducted in English) but in all the women's conferences I attended during my field

${ }^{107}$ Because of technological development, the wide use of the internet and text messaging as a cheaper and alternative form of communicating from different locations instantly, the on take of Arabic transliteration has resulted in the use of symbols and numerical characters in place of the alphabetic characters non existent in the English language. This has now become formalized and is readily available. Access to the list can be seen at http://www.transparent.com/arabic/common-arabic-words-and-sentences-part-i-transliteration/

${ }^{108}$ Interview 5, the term mara meaning woman implies sexually active non virgin while the term benet meaning girl is usually used in reference to young unwed and innocent virgins. 
research in Lebanon. Feminists made an effort to use the modern standard Arabic language in public venues (but not in the interviews taped that were less technical and more informal). Feminist agents' translation of woman helped them circumvent the family honor filter that is so deeply embedded on the streets and in colloquial representation. This type of translation does not conform to the implementation of an international gender equality norm but rather shows how campaigners found it necessary to be co-opted to the social value placed on woman's honor found in discussions of virginity.

According to a prominent activist and founding member of the Lebanese Women's Network, the failure of the national campaign for the elimination of discrimination against women in the penal code played out in the campaign's relationship with law makers. At one of the debate sessions, the law makers indicated a willingness to amend Article 562 commonly referred to as the "honor" article. They offered to consider a request to change the article so that it allows for leniency not only towards men who have committed murder in circumstances that would define the murder as an honor crime, but also towards women. But, according to the position represented by my interviewee: "We don't want that kind of change; we want the article to be completely removed. Anyways there is no such thing as a woman's honor crime; it is unlikely that a woman is going to kill her husband if she catches him with another woman. It is the woman that is considered the man's honor, not the man that is a reflection of her honor." ${ }^{109}$ But the other organizations present at the session agreed to the proposal. According to my

\footnotetext{
${ }^{109}$ Interview 2
} 
interviewee, they wanted to remain united with the campaign, but they believed in a different strategy in order to get what they could and get the recognition for the change as well. The result was a split in the campaign between those who wanted article 562 to be removed entirely and those who wanted to play it safe and ask for an amendment to the article. In the end, those who supported an amendment withdrew from the network and the campaign, and with their support parliament amended the law to allow for lighter sentences for honor murders for women as well. This kept in place the justification of honor killings; however, it now applied equally to men and women. ${ }^{110}$ What took place in this case scenario is an example of how some translations encounter not only social filters but also faithless translators driven by personal ambition and pragmatic thinking. Women's rights campaigns across Lebanon have seen this type of defeat, leading some to question whether a women's movement actually exists in Lebanon. Several of my interviewees contended that there are women's organizations with professional leaders but no movement.

The Family Cohesion Filter

The second filter operative in the violence against women campaigns is the family cohesion filter. As wives and mothers, Lebanese women are perceived as ultimately responsible for the preservation of the family. Because women are not only considered carriers of honor but protectors of the home, a lot of pressure is placed on them to appropriately manage the household and the relationships within it. This leaves women with a great sense of guilt if they are unable to live up to that ideal. In cases of domestic

\footnotetext{
${ }^{110}$ Interview 2
} 
violence women allegedly violate the ideal. Women who are caught in this web of interpretation are less likely to stand up against such violence, more likely to blame themselves for the violence and fear familial repercussions if they were to make such violence a public matter. ${ }^{111}$

And who would blame them? In my interviews it became painfully clear that translating the international norm of combating domestic violence came up against a tough filtering process centered on the value of family cohesion. The problem lied in what to do if you are a Lebanese woman in a violent familial relationship. There is broad agreement among violence against women experts internationally that there is no reasoning with an abusive husband. The welfare or therapeutic models, which suggest, mediating between the abused and the abuser in order to preserve the family, used as solutions to family violence were studied and dismissed as inappropriate remedies during the 1986 expert group meetings on domestic violence in Vienna. ${ }^{112}$ However, both the Ministry of Social Affairs in 2005 and my interviews indicate that this is still a predominant remedy advocated in Lebanon.

As in society, so within the state there is a strong commitment to preserving the family at all cost as evident in a report issued by the Women's Affairs Section of the Ministry of Social Affairs, on September 19, 2005. In a response to the Special

\footnotetext{
${ }^{111}$ Ministry of Social Affairs (MOSA) and Lebanese Council to Resist Violence Against Women (LCRVAW) [Publication]. The Directory of the Meetings Concerned With the Enlightenment Program on the subject of the prevention of violence within the family from the "Guide Book for Training Sessions Involving Prevention Against Domestic Violence.” 2005.

112 Joachim, Jutta. "Framing Issues and Seizing Opportunities: The UN, NGOs, and Women's Rights", International Studies Quarterly, v. 47(2003), 257
} 
Rapporteur on Violence Against Women the Ministry of Social Affairs Women's Section

wrote that their work on combating violence against women within the state structure included a constructive solution to the dispute between the two parties.

In some cases of mediation of this kind, the wife may withdraw her complaint against the husband in exchange for a pledge, which is written into the investigation report, that he will not assault her again in the future. This kind of reconciliation is carried out in the presence of the investigator and under his personal supervision and the investigation report must record the fact that the two parties have reached agreement and have had their demands met without any pressure or coercion. This is an important procedure, since it ensures the cohesion of the family and provides a legal deterrent against the recurrence of such violence. It also protects the wife, who retains the right to file a complaint against the husband should he break his pledge. ${ }^{113}$

This choice of action plan activates the family cohesion filter deeply informed by the state and social structure. This position on how to confront domestic violence came up also in my interviews. It is evidence of a "faithless translation" of the international norm to combat violence against women. It indicates a breakdown of the international understanding of the issue. The first to point to a problem was one of my interviewees at KAFA, who alerted me that violence against women is not uniformly defined in Lebanon. Her claim was that even the professional approach to violence against women varied:" For example for some organizations they use the negotiation with the husband and this is something internationally proven that you cannot change the abuser if he does not want to change or without treatment. He is not sick but he needs treatment." ${ }^{114}$ I was

\footnotetext{
${ }^{113}$ Look to the response of the Women's Affairs Section to letter No. 50214 (89-9) from the Special Rapporteur on violence against women. For more details on the section that outlines the need to work with the abuser as outlined on page 16 in the section titled "Protection and Services for Battered Women"

${ }^{114}$ Interview 5
} 
so intrigued by this idea that I chose to ask more activists about their thoughts on "negotiating with an abuser", and to my surprise they mostly seemed to think that it was the first step to take. While one activist tried to strengthen her position by paralleling such an idea to international relations and the need to negotiate with our enemies, the others just pointed to the fact that above all the goal was to preserve the family. ${ }^{115}$ They can be viewed as a "faithless translators" being co-opted by their own subject position reinforcing the notion that the social rules in Lebanon identify with the norm that a woman's actions and rights are not a reflection of her individuality but more of her familial and communal ties.

For the most part, the reality of the Lebanese context is that people resist the idea of breaking up the family and label it as Western. This idea although closely tied to the family honor filter also includes a larger communal reference. It is what some would describe as pride in their national culture and the need to define this way of being as superior to foreign cultural practices. This is not a unique characteristic of Lebanon; however it is strongly embedded in Lebanese society, and exhibited itself in the interviews and conferences attended. Non-governmental organizations do not swim against this stream. As one of my interviewees, an academic sociologist and leader of a prominent NGO proclaimed: "There are certain things we can progress in, open up, and push forward but the basics we hold onto. The idea about preservation of the family is fixed, and this we will never give up on or change. Because in the West they are dying to

\footnotetext{
${ }^{115}$ In Interview 8, Interview 12, and Interview 15 my interviewees all used the same language in discussing domestic violence and family preservation.
} 
rebuild the notion of the family because everything has fallen apart". ${ }^{116}$ The same interviewee went further on the defensive by pointing out that while in the Arab world and Lebanon violence against women exists it is not as pervasive as it is in the West. "In the States a woman is being beaten every second of the day. Over here we are in a much better position than on the outside... And where is it that we really see domestic violence in this country; it is mostly seen amongst the rural people that are still following old patriarchal traditions, those that are not educated“" ${ }^{117}$ Not only is this a reflection of how women activists juxtapose Western strategies of combating violence against women as in direct conflict with the fundamental values of Lebanon's communal structure it also is evidence of common misunderstandings of the pervasiveness of violence against women that is not simply a reflection of education.

This was not the first time I had heard or seen this reaction, so I could not brush it off as an isolated opinion. At the launch of the campaign towards the protection of women from family violence a representative of the European Union explained the importance of the campaign because of the extent of domestic violence in Lebanon. He added that there is evidence from research that thirty percent of families in Lebanon are affected by domestic violence. ${ }^{118}$ The room was silent and the conference continued. At

\footnotetext{
${ }^{116}$ Interview 15

${ }^{117}$ Ibid.

${ }^{118}$ A study conducted by the department of family medicine at the American University of Beirut and the Psychology department of the University of Southern California Los Angeles estimated that $35 \%$ of those interviewed reported experiencing domestic violence. Usta, Jinan, Jo Ann M. Farver, and Nora Pashayan, "Domestic Violence: The Lebanese Experience", Public Health, 121, no. 3, 208-219
} 
the end of the conference there was an award ceremony for those that had tirelessly collaborated on the draft domestic violence law (bill). One of those awarded was a renowned judge known for his reformist visions and his support of feminist goals. He accepted the award graciously but had to respond to the European Union representative on his earlier remarks. He doubted the statistics cited by the representative and resisted the idea that the extent of domestic violence in Lebanon was so high. He went on to defend his nation's honor by citing the extent of violence against women perpetrated in Western countries. Two months later at the beginning of a follow up roundtable discussion he once again made reference to the representative's comments but this time he came prepared with statistics on violence against women incidents in France and the United States amongst other Western countries.

Combating violence against women is addressed by Lebanon and its civil society. However, the process the norm undergoes involves confronting filters of a complex society. These filters are steeped in a deeply ingrained patriarchal order where women's rights are translated through a culture of violence and the continued commitment to family honor, cohesion, and the nation.

\section{Conclusion}

While the international norm on combating violence against women has crossed boundaries into Lebanon's context, its translation and the filters it encounters has changed the norm in three fundamental ways. First, violence against women gets subordinated to and dissociated from the culture of violence embedded in a warring state. Second, violence against women by agents, social and state structures is translated so as 
not to violate the principle of family preservation. Lastly, both the state and social structures translated violence against women without circumventing local conceptions on gender and sexuality and their relationship to rights where women's honor, virginity and their relation to the family are the foundations for maintaining these distinctions. 


\section{Chapter 4}

\section{Campaigns for Gender Equality Norms in Personal Status Codes}

Lebanon's consociational democracy is based on a complex power sharing agreement rooted in ensuring confessional proportionality in politics. The legal preservation of confessionalism is found both in politics and in the community. While article 7 of the 1990 Tai' $f$ constitution declares that all citizens have equal legal rights in the eyes of the law there are no specifications for the principle of equality between men and women. Furthermore, article 9 of the constitution has institutionalized the right of religious communities to govern all issues attached to the family usually referred to as the personal status laws. With 18 recognized confessions and up to 15 different confessional laws this complex system not only allows for inequality between men and women but also allows for inequality among Lebanese women. ${ }^{119}$ One of my interviewees, an academic researcher, stresses the need to centralize all laws within a secular state structure. Making her case against the discrimination that religious communities apply in family law because of the state's relinquishment of that jurisdiction she said the following:

"The common ground for all is that the state has the responsibility to intervene to guarantee the protection of the citizen's right. For example it is not beneficial to tell me that the Islamic Shi'a law forbids a mother from taking custody of her two year old child (the law requires that a boy's guardianship at the age of two must be remanded to the father). Lebanon has signed the Convention on the Rights of Children that takes the criteria of the best interest

\footnotetext{
${ }^{119}$ Lamia Rustum Shehadeh, "The Legal Status of Married Women in Lebanon", International Journal of Middle East Studies, 30, no. 4 (Nov. 1998), 501-519
} 
of the child. If the confession is not acting in the best interest of the child then the state must intervene. There are no benchmarks for interference." ${ }^{120}$

The Convention on the Elimination of all Forms of Discrimination against Women (CEDAW) has outlined the responsibility of states to ensure that all laws relating to the family must ensure equality between men and women. Article 16 covers this area in detail addressing rights of marriage, divorce, and towards children as they apply to both. All Arab states have declared a reservation to all or parts of article 16 of the convention. Lebanon's reservation to Article 16 was made on the grounds that it is beyond the reach of the state as all familial matters and laws fall under the jurisdiction of the confessions and the Personal Status Codes, thus giving religious communities prerogative over legal matters pertaining to the family is in tension with the country's commitment to CEDAW and numerous other international conventions and declarations.

When the United Nations General Assembly in resolution 34/180 designated 1994 as the International Year of the Family, the Committee on the Elimination of Discrimination Against Women issued a recommendation (General Recommendation 21) focusing on all the articles of CEDAW that directly refer to gender equality in family and marriage. In addition the committee pointed to other conventions and declarations which address the status of women within the family, including the Universal Declaration of Human Rights, and the International Covenant on Civil and Political Rights. Lebanon is bound by both of these. The articles highlighted by the Committee included article 15, which calls on states to ensure legal equality for men and women in all civil matters, and the familial matters that press upon men and women's equal rights in marriage,

\footnotetext{
${ }^{120}$ Interview 19
} 
dissolution, and child rearing outlined by article 16. While CEDAW has made it permissible for states to enter reservations upon ratification, that provision is only applicable as long as the reservations do not contradict or violate the spirit of the text. ${ }^{121}$ The Committee on the Elimination of Discrimination against Women in its opening and closing statements of General Recommendation 21 reiterates the responsibility of states to ensure gender equality in all familial and marriage matters. It also affirms its commitment to women's rights as human rights while acknowledging the important role that custom and culture play in shaping the roles and rights afforded to men and women. The Committee calls upon states to carry out their duties by ensuring that even where familial matters are delegated to ethnic or religious authorities the application of laws should not be in contradiction to the principles embedded in CEDAW.

The Committee has said that reservations that violate the spirit of the Convention on the Elimination of all Forms of Discrimination against Women are impermissible. The committee makes it quite clear that where gender equality is concerned there are no articles in the convention that leave room for reservation, and that all the articles are tied to one another and reinforce the overall international norms of men and women's equality in family matters. ${ }^{122}$ It has identified Articles 2 and 16 that outline the principles and measure of discrimination against women and demarcate the responsibilities of gender equality in family matters as the foundation of the convention. In a shadow report to the

${ }^{121} \mathrm{http} / / /$ www.un.org/womenwatch/daw/cedaw/reservations.htm accessed January 19, 2009

${ }^{122}$ For a more detailed look at general recommendation 21 of the committee adopted by the General Assembly go to http://www.unhcr.org/refworld/category,LEGAL,CEDAW,,,48abd52c0,0.html last accessed February $5^{\text {th }}, 2009$ 
Committee Lebanese women's organizations have argued that the international norms outlined in Article 16 are not being implemented in Lebanon due to the reservation made by the state. ${ }^{123}$ The Committee has urged Lebanon to reconsider its reservations as they violate the fundamental values of the convention. ${ }^{124}$ This chapter seeks to trace how women's organizations are translating international norms on equality in the family in the context of the filters that appear in Lebanon. I seek to identify the filters in play and how feminist agents navigate these filters as they campaign to address and amend personal status codes.

Lebanon has inherited and kept the Ottoman system of governance which delegates family law to the confessional groups. Lebanon's multi-confessional democratic state has no secular civil family law, but up to fifteen systems of confessional law. The consensus is that these religious governorates have been detrimental to women's rights. How have women's organizations dealt with trying to achieve gender equality in personal status code in this context? What are some of the filters that appear in this quest? How have the translations into the Lebanese context changed the norms established by Article 16?

In order to answer these questions I start with an outline of the international equality norms in the family established by the Convention on the Elimination of all

\footnotetext{
${ }^{123}$ Lebanese shadow report prepared by the Committee for the follow up of women's issues and other women's organizations December 2007 presented to the Committee for the Elimination of Discrimination Against Women at the $40^{\text {th }}$ session, January $14^{\text {th }}$ - February 1,2008

${ }^{124}$ Committee on the Elimination of Discrimination against Women, $33^{\text {rd }}$ Session, May 22, 2005 Concluding comments on Lebanon, p.3 http://www.un.org/womenwatch/daw/cedaw/cedaw33/conclude/lebanon/0545048E.pdf last accessed November 10, 2009
} 
Forms of Discrimination against Women. Second, a brief review of the contemporary campaigns that address Personal Status Codes will lay the foundation to begin investigating the change international norms undergo as they filter through to a local context. The subsequent section introduces the filters that are activated by this process and shows how they impact the translation of the gender equality norms in question. I conclude with a brief review of the process of transposition.

Lebanon, Convention to Eliminate All Forms of Discrimination Against Women, and Personal Status Codes: Tackling Women's Equality in Family Law

Lebanon acceded to the Convention on the Elimination of All Forms of Discrimination Against Women on April $21^{\text {st }}$ 1997. This move was an affirmation of its constitutional commitment to the equality of all Lebanese citizens. However, also due to the constitutional deferral of all personal and family issues to the confessional communities reservations were made to article $16(1)(\mathrm{c}),(\mathrm{d}),(\mathrm{f})$, and (g) all of which refer to the elimination of

discrimination against women in all matters relating to marriage and family relations ... [I]n particular [state parties] shall ensure, the same rights and responsibilities during marriage and at its dissolution, the same rights and responsibilities as parents irrespective of their marital status... with regard to guardianship, wardship, trusteeship, and adoption of children, or similar institutions... same personal rights as husband and wife, including the right to choose family name, a profession, and an occupation on a basis of equality of men and women. ${ }^{125}$

Lebanon's multi-confessional composition and its complex political power sharing structure is an example of a multicultural accommodation policy whose objective

${ }^{125} \mathrm{http}$ //www.un.org/womenwatch/daw/cedaw/text/econvention.htm 
is to respect and preserve group rights, but which leaves certain group members, namely women, vulnerable to discrimination. ${ }^{126}$ Lebanon's political structure of proportional representation can be traced back to 1861 and is tied to maintaining a balance of power and civil order. The end of the civil war ushered in an amended constitution known as the Tai'f Accord with a provision that the consociational democracy would be phased out into a non-confessional democracy. With an exodus of migrants and a shift in confessional proportions there is a heightened fear among those in power that they will lose out, and they have become more entrenched in seeking to maintain the status quo. ${ }^{127}$

Chances are slim that Lebanon would do away with the consociational democracy based on confessional proportionality because this form of government has existed for almost one and a half centuries. At the same time, the global gender equality regime is growing stronger, challenging discrimination within protected groups. Women's issues are thus inextricable from the system designed to maintain order in Lebanon and face powerful patriarchal social and state structures. As they pursue international gender equality norms, intergovernmental agencies and NGOs have yet to find a way to effectively address these challenges.

Constitutional experts and lawyers, including those I interviewed, remain adamant that while the state has deferred its responsibility to govern the personal and familial

\footnotetext{
${ }^{126}$ Shachar, Ayelet, "Group Identity and Women's Rights in Family Law: The Perils of Multicultural Accomodation", The Journal of Political Philosophy, Vol.6 No. 3, 1998, p.285-305.

${ }^{127}$ Marie-Joelle Zahar,'Power Sharing in Lebanon: Foreign Protectors, Domestic Peace, and Democratic Failure," in Sustainable peace: power and democracy after civil wars, ed. Philip G. Roeder and Donald Rothchild (New York: Cornell University Press, 2005),219-240
} 
affairs of its citizens, the state has not been relieved of its duty to protect all citizens and must oversee the religious courts to ensure that violations of citizen's rights do not occur. ${ }^{128}$ According to one researcher and lawyer as long as issues pertaining to women's rights within the family revert back to the authority of the eighteen recognized religious confessions, the women's movement and gender equality cannot be solidified. According to her, women will always be subjected to discrimination when religion is deciding their fate. ${ }^{129}$ The two main problems that enable this discrimination are religious court rulings based on inherited patriarchal traditions coupled with a system that is dominated by an all male staff. "All religious court justices in Lebanon are males, and the still emotionally charged issue of gender equality due to the firmly ingrained patriarchal traditions in Lebanese society makes judicial decisions inevitably colored by their personal backgrounds, experiences, and ideologies. ${ }^{\circledR 30}$ The result is that patriarchy (male dominance in society and in politics) continues to be deeply embedded privately in the family and publicly in the confessional legal system. Women in Lebanon across confessions are born into their fathers' homes and when they marry they immediately lose every part of their identity and freedom to their husbands both privately and legally. According to Lamia Rustum Shehadeh's analysis of the Lebanese legal institution and personal status codes once a woman is married in many areas of the law and within the

\footnotetext{
${ }^{128}$ Interview 19

${ }^{129}$ Interview 19

${ }^{130}$ Ibid.
} 
household she is reduced to a second class citizen by her inability to take fundamental decisions without the consent of her husband. ${ }^{131}$

In the following section, I will show how women's organizations and agents have translated the international norms established in article 16 of CEDAW against the filters activated in Lebanon. First, I provide an overview of the contemporary personal status codes campaigns in Lebanon and the structures they address. Second, I will identify the filters that appear in those campaigns with an analysis of the way they filter translation of international norms.

\section{Lebanon's Personal Status Codes Campaigns}

The 1990s brought with it the end of the Lebanese civil war, Syrian tutelage, the weakening of militia organizations, and a flood of non-governmental, human rights, and other organizations that made their voice heard in domestic politics. The campaigns to address and reform personal status code were part of this inundation of activity. Three campaigns will be discussed in the following. They include: (a) Campaign 13/15, whose aim is to reform custody laws across confessions and to draft the rules on parental responsibility, (b) Women's Rights to Marriage and Divorce in Islam, which is aimed at empowering women by arming them with the rights provided through a marriage contract according to Sunni Islamic law, and (c) Civil Marriage is a Civil Right, a campaign in pursuit of a secular civil marriage law.

\footnotetext{
${ }^{131}$ Lamia Rustum Shehadeh, "The Legal Status of Married Women in Lebanon", International Journal of Middle East Studies, 30, no. 4 (Nov. 1998), 501-519
} 
Campaign 13/15

The Network for the Rights of the Family formed in 2005 and launched Campaign 13/15. In our interview, one of the founding members, a prominent member of the women's rights movement, past President of the Lebanese Women's Council, activist and lawyer, told me how Campaign 13/15 came about and for what purpose. She had proposed a television program to educate women on their rights in family law to the women's television network known as Heya. The program, while initially focused on Lebanon, was broadened to include several other Arab countries. After running for some time a theme began to appear, the majority of callers identified the loss of custody of their children in a divorce as their biggest issue. It became evident that women would endure abuse to avoid such a loss. Of the fifteen personal status laws in Lebanon all agree that the children belong to the father (referred to as guardianship by law) and in the event of divorce the children must be nurtured by their mother (referred to as custody by law) until they are no longer in need of her nurture, at which point they are returned to their father. All confessions except for the Orthodox and Evangelical Christians deem the appropriate transfer of custody age to be less than 13. Indeed, the Orthodox and Evangelicals recently have amended their custody age requirements to fifteen years of age for both sexes. The purpose of Campaign 13/15 is to amend custody rights across all personal status laws to allow transfer of custody to the father not before the age of 13 for boys and 15 for girls. The campaign is also to draft a law on the rules that govern parental responsibility. The campaign began in 2005 and is ongoing. It draws directly from CEDAW article 16 (1) d and f, whose guiding principles are the equal rights and 
responsibilities of parents in reference to the children irrespective of marital status. The convention holds that all decisions made must be in the best interest of the child.

Women's Rights to Marriage and Divorce in Islam

The second campaign to be addressed is the campaign on Women's Rights to Marriage and Divorce in Islam, a campaign launched by the National Committee for the Follow Up of Women's Issues in the Beirut region of Lebanon in $2007 .{ }^{\text {This }}$ is a nonsectarian network civil society organization made up of several non-governmental organizations none of which are faith based. Why (Sunni) Islam and not any of the other confessions in Lebanon? This has come up several times considering that Lebanon as a state does not have an official religion. One of the interviewees suggested that although there are 15 different personal status codes they are all drawn from an overall general family law of the Ottomans which is based on Islam and more specifically the Sunni confession that relies on the Hanafi School. It also seems that the focus on Islam per se is related to two things. First, most Arab countries in the region have Islam as the state religion and the women's regional movement to amend personal status codes is focused on Islam as the main religious doctrine. This has spilled over into Lebanon's projects. Second, all the projects funded are by Western organizations that have a deep interest in continuing an East-West dialogue in reference to women's rights campaigns. ${ }^{132}$

\footnotetext{
${ }^{132}$ For more information on the various personal status laws in Lebanon go to portal.unesco.org/shs/fr/files/8090/11313662721Women_in_Personal_Status_Laws.pdf/Women_ in_Personal_Status_Laws.pdf last accessed November 2, 2009
} 
The campaign lasted a few months and its objective included raising awareness of women's rights in Islam in the areas of marriage and divorce. The campaign itself included activities such as meetings with religious leaders, distributing leaflets containing Quranic verses on marriage and divorce, increasing awareness of women's right to partake in creating a marriage contract, as well as presenting a sample of a contract to the religious centers of the Sunni, Shi'a, and Druze communities. This campaign has been documented in the form of a published booklet prepared by activists and scholars of the region and by members of the Committee for the Follow Up of Women's Issues. The campaign speaks directly to all subsections of article 16 and intends to normalize equal rights and responsibilities of men and women in marriage and dissolution by reinforcing the compatibility between the Islamic dictates and CEDAW.

I describe this campaign as an Islamic feminist campaign by a committee that would not necessarily agree with being called Islamic feminists. It is important to raise this issue for several reasons. First, after having asked several of those interviewed about collaborating with faith based organizations the answer was usually along the same lines that if the paths intersected they were ready to work with them but that there were no efforts seeking out this collaboration. Secondly, it is very clear that where family matters are concerned the right of return to source and authority in Lebanon lies in the hands of religious doctrine; this forces activists to address both the social and confessional structures from a religious platform. Lastly, the regional women's movements are informing Lebanon's personal status codes campaigns and are based on Islamic reform. Thus, while this campaign is not Islamic in the sense that campaigners are not Islamic 
feminists trying to use reformist interpretations, it seeks to talk the language of Islam and argues from an Islamic perspective. One interviewee put it simply by saying that all they are attempting to do is inform Islamic women of the rights that they have from a religious perspective. The purpose is for women to know what they are able to request and preserve in the marriage contract. ${ }^{133}$

\section{Civil Marriage is a Civil Right Campaign}

Campaigns to introduce a civil marriage law in Lebanon can be traced to the 1950s, but have not managed to come to fruition. The last attempt to implement a civil marriage took place in 1998 where activists tried to convince law makers and religious leaders of the value and need for this choice. An analysis of the campaign reflects the resignation and little enthusiasm future campaigns produce as most people find this goal to be out of reach. ${ }^{134}$ This latest campaign launched in 2007 is a follow up to the last serious attempt at introducing civil marriage by the late President Hrawi in 1998. The purpose of the campaign is to garner public support for a draft law on civil marriage as an option for those who wish to marry outside of their religious communities. Many see this also as an attempt at secularizing Lebanon and moving it a step closer to doing away with sectarianism. The campaign is ongoing and is run by a group of students from the American University of Beirut. The campaign was initiated by a professor at the

\footnotetext{
${ }^{133}$ Interview 18
}

${ }^{134}$ This sense of pessimism can be found in Hayeon Lee "Join the Facebook group 'All for Civil Marriage in Lebanon': The future of civil marriage in Lebanon maybe in the hands of a facebook group.'NOW Lebanon, August 21, 2008

http://www.nowlebanon.com/NewsArticleDetails.aspx?ID=55684 last accessed February 17, 2009 
university but is organized and managed by the student group through a Facebook account. I will focus on the campaign from 1998 to see how the international norm of women's equality in marriage has translated into the domestic context against the filters that come into play.

The Confessional-Political Filter

In Lebanon it is difficult to understand how the women's movement has failed to advance beyond a certain threshold considering the strength of the global gender equality regime and the pressure that comes along with it. Upon first glance most would think that Lebanon would be a prime candidate in the Middle East for expedient gender legal reform and social advancement because of the coexisting multicultural appearance where you find women clad in bikinis along the beaches and women adorned in a veil across the valley. However, the truth is that Lebanon is far behind other Middle Eastern and North African countries where the push for gender equality is concerned. ${ }^{135}$ One of the most entrenched reasons is what I call the “confessional political filter". Lebanon's political confessional power sharing system has become the pit stop for every personal status reform proposal. As mentioned above Lebanon's power sharing system is based on a 5050 split for senior government positions between the Christians and the Muslims, with the President always being of the Maronite denomination. With 18 recognized confessional communities included in a complex power sharing agreement the fear of losing one's share is heightened. What would happen if a civil marriage law was passed and people

\footnotetext{
${ }^{135}$ Ghada Khouri, "Caught in the Middle: Women in Lebanon.” WIN Magazine. 4 December, 2001. http://www.geocities.com/Wellesley/3321/win13b.htm last accessed January 26th 2009
} 
could easily marry across confessions? The defeat of every attempt to pass such a law is an indication of the fear that the idea evokes. The Economist in a 1998 article (commenting on the last attempt at passing a civil marriage law) asked wisely whether Lebanon's consociational democracy "helps preserve communal harmony- or contributes to discord by institutionalizing the domination of particular groups". ${ }^{136}$ Women's organizations wonder the same thing when they find that all their "issues are embedded in the political situation where they have not managed to separate women's rights from the political agenda". ${ }^{137}$

Attempts to implement article 16 of CEDAW are found in the "civil marriage is my civil right campaign". However, the reaction to the campaign made it seem like the campaign was not about achieving gender equality but more about doing away with the confessional political power sharing system. The state's constitution that empowers religious leaders with the right to object and interfere in any legislation proposed that falls within their jurisdiction has rejected gender equality reforms pursued by the campaign. ${ }^{138}$ Instead these reforms have been reframed in terms of confessional politics filtering the message and changing the norm in the process. Describing the push for change as power based, a lawyer I interviewed discussed the 1998 proposal as one that was heavily supported by the Christian community until “...they got to a stage where the heads of the confessional communities (men of religion) all got together. They raised the

\footnotetext{
136 “Thinking the Unholy Unthinkable: Lebanon” The Economist. March 28, 1998, p.45

${ }^{137}$ Interview 6

${ }^{138}$ Ofeish, Sami A. "Lebanon's second republic: secular talk, sectarian application "Arab Studies Quarterly (ASQ). 21.1 (Wntr 1999): 97(2).
} 
issue of bargaining a civil marriage law and immediately it became a political issue and they were told okay sure let us put the question of reconfiguring proportional representation on the table. When they were confronted with that reality the decision was to take the question of civil marriage off the table." ${ }^{139}$ Keeping the institution of marriage within the hands of confessional communities becomes necessary to maintain this political balance. It limits marriage across confessions and prevents a challenge to Lebanon's confessional make-up thereby preventing a political upset. ${ }^{140}$

The failure of passing a civil marriage law coupled with the influence of religious leaders had women's organizations searching for alternative ways to translate the gender equality norms established by CEDAW. Against a current of confessional political power, agents in women's organizations find themselves torn between national and sectarian loyalties as activist Wadad Shakhtoura has said. ${ }^{141}$ Women's rights organizations must continuously massage and navigate against this political current. The alternative has been for women's organizations to translate international norms against the state structure circumventing local filters by addressing the status of women in personal status codes. According to the lawyer and activist I interviewed, while she supports the creation of a uniform personal status law "until that becomes a reality, working on the personal status codes is a must. All the marriages performed in Lebanon

\footnotetext{
${ }^{139}$ Interview 19

140 Sherifa Zuhur, "Empowering Women or Dislodging Sectarianism? Civil Marriage in Lebanon", Yale Journal of Law and Feminism, Vol. 14:1 (Summer 2002), 177-208

${ }^{141}$ Seminar on Gender Equity in Lebanon, October $11^{\text {th }}$ and $12^{\text {th }} 2005$ Proceedings Report www.undp.org.lb/mdgs/discussions/GEinLeb2005.doc last accessed January $26^{\text {th }} 2009$
} 
are religious marriages. We cannot work on something for the future and forget about the past. We cannot apply a civil marriage law without educating on the civil marriage law." 142

Personal status campaigns are dictated by this confessional political filter and agents are trying to navigate and adapt their translation of CEDAW in a way that is not threatening to those "men of religion" (rjeil el din) in power. The way Campaign 13/15 came to be the project it is today is a result of this sort of translation and it took place early on in its development. Initially the movement realized that the Personal Status Codes were harboring violence against women and that clearly there needed to be a change; so they devised a project that was to build a state law for the family. However, they soon realized that creating a uniform civil code would not suffice as it does not address the current confessional system that continues to treat the family as a private affair therefore challenging the foundation of global gender equality regime. The work that must be done "is in the now and in the possible,"143 i.e., it needs to focus on the confessional system that maintains exclusive control of the private affairs of the family and reinforces gender inequality through its application of custody rules. Campaign $13 / 15$ has been ongoing since 2005 , and even with the support of several religious leaders it always seems to be at an impasse. The campaign founder, a vociferous lawyer, talked about how she had initially gotten the approval to move along with the campaign from the top Sunni Mufti, but at the end, after having made the rounds with politicians and

\footnotetext{
${ }^{142}$ Interview 7

${ }^{143}$ Interview 8
} 
other religious leaders, the draft came back to the Mufti "and he declined with the excuse that he would be under fire from the men". This activist understood this defeat as one that is rooted in gendered power relations: "for men this is a means of exchange, a means to put pressure on the woman." ${ }^{\text {144 }}$ But one could equally interpret the situation of one in which the confessional political filter asserted itself.

Campaigns attempting to implement gender equality in Lebanon have been forced to translate the international norms found in CEDAW against a powerful confessional political filter with patriarchal traditions deeply embedded in Lebanon's legal and confessional structures. While Lebanon's constitution stresses the equality of all its citizens the multiple confessional community structures in place are riddled with rules that maintain women's disadvantage within the proceedings. Parallel to these established structures is the communal ordering of gendered relations where men within the family also assume the power position in relation to women.

In Line With the Divine Filter

The conflation of religion and politics has created a precarious situation for the campaigns tackling gender equality within the personal status codes. Article 9 (Conscience and Belief) of the Lebanese Constitution affirms the role of religion as an important staple of Lebanon's national identity. The Constitution, "in rendering homage to the Most High shall respect all religions and creeds and guarantees, under its protection, the free exercise of all religious rites provided that public order is not

\footnotetext{
${ }^{144}$ Interview 8
} 
disturbed." ${ }^{145}$ Article 9 has given religious leaders the power to claim that some issues are simply not up for dialogue, or that some issues are too difficult to address. The claim is that rules ascribed in the scriptures are divine and any law that circumscribes the written word is an abomination. Amending personal status codes means you have to address religious leaders and debate with them on their own turf and within the confines of religious tenets.

Suad Joseph states "underwriting this legal pluralism in family codes is a state-building enterprise based in sectarian pluralism." ${ }^{146}$ The political elite elected are representatives of their religious communities and they have "used their position in government to subsidize their personal followings.. ${ }^{147}$ This has created a form of patron-client relationship between religious leaders and politicians that can be mobilized both ways, meaning religious leaders have used their position to pressure politicians into submission when draft laws that go against the benedicts of religious institutions are presented.

The constitutional lawyer and activist I interviewed said that Lebanon must be held accountable for neglecting its duty to govern familial issues. According to her the amended preamble to the constitution of 1990 "says there are some fundamental divine scriptures that cannot be touched, but what is also true is that every religious re-reading is a historical one. Secondly, this reading is open to debate and to be changed and to change

\footnotetext{
${ }^{145}$ Lebanon's amended 1990 constitution

${ }^{146}$ Suad Joseph, "The Public/Private: The Imagined Boundary in the Imagined Nation/State/Community: The Lebanese Case”, Feminist Review Vol. 57, Autumn 1997, 73-92

${ }^{147}$ Ibid
} 
of interpretation." ${ }^{148}$ In this she implied that certain religious writings can have both direct and indirect meanings that make room for fluid interpretations. This is the same assertion made by Islamic feminists and Islamic reformists that point to certain Qur'anic and Hadith writings that can be interpreted to be applied to today's context. Above all she sees this reformist position as one that should apply to the state saying that "the government's authoritative source (marja3 commonly used Arabic term for religious authoritative source $)^{149}$ is the constitution and that if anyone is to say that the government must seek permission from religion to oversee the home and the family then she is in the wrong. This would be an indication that there is a shortcoming in the state."150 This view and understanding while applauded is not shared by most activists, who believe this understanding to be a future aspiration or achievement for future generations. ${ }^{151}$

All of the personal status codes campaigns found that the translation of the status of women in family matters must be addressed from a confessional platform socially and legally. And when they tried to address personal status codes outside of this platform the religious leaders were never too far to sound their alarms. The Civil Marriage Is a Civil Right campaign of 1998 is a clear example of this. A member of Bahithat and supporter

\footnotetext{
${ }^{148}$ Interview 19

${ }^{149}$ Because of technological development, the wide use of the internet and text messaging as a cheaper and alternative form of communicating from different locations instantly, the on take of Arabic transliteration has resulted in the use of symbols and numerical characters in place of the alphabetic characters non existent in the English language. This has now become formalized and is readily available. Access to the list can be seen at http://www.transparent.com/arabic/commonarabic-words-and-sentences-part-i-transliteration/

${ }^{150}$ Interview 19

${ }^{151}$ Interview 7
} 
of instituting civil marriage in Lebanon said "Even when someone raises the question of instituting civil marriage law it is immediately turned down with the pretext that you are invading religious territory." 152 Zuhur's analysis of the campaign has shown that the draft law presented to the Council of Ministers had certain provisions that were in direct conflict with religious prescriptions. One of the contentious areas was the area of law which made it possible for a Muslim woman to marry a non-Muslim which is a direct violation of Islam. ${ }^{153}$ Another area in contradiction with Islamic principles is the clause which allowed for adoption. ${ }^{154}$ While the civil marriage law has been cited to be in contradiction with Islamic principles and received vociferous opposition headed by the Sunni religious community, the religious leaders of all the confessional communities in Lebanon fought to prevent the passing of the Hrawi proposed law as it would have resulted in their loss of control over the family as well as loss of control in politics. ${ }^{155}$ These are some of the factors that had the proposed law put on hold with religious leaders pressuring political leaders by drawing on their fear of going against the will of God as

\footnotetext{
${ }^{152}$ Interview 19

153 Sherifa Zuhur, "Empowering Women or Dislodging Sectarianism? Civil Marriage in Lebanon", Yale Journal of Law and Feminism, Vol. 14:1 (Summer 2002), 177-208

${ }^{154}$ Hayeon Lee "Join the Facebook group 'All for Civil Marriage in Lebanon': The future of civil marriage in Lebanon maybe in the hands of a facebook group.'NOW Lebanon, August 21, 2008 http://www.nowlebanon.com/NewsArticleDetails.aspx?ID=55684 last accessed February 17, 2009

${ }^{155}$ Maurus Renkowski and Sofia Saadeh, “A nation divided: Lebanese confessionalism” in Ed. Haldun Gulalp Citizenship and Ethnic Conflict: Challenging the nation-state, Routledge Research in Comparative Politics, Routledge NY 2006
} 
well as the fear of losing political support from constituents that support their religious leaders.

For a Campaign 13/15 activist "the origins and make up of people in our area are based on religion; what are we to do?" She told me of an incident at a regional conference when an activist stood up to demand that the state govern inheritance laws. She replied to her "sister this is our heritage. The heritage is always a movement of interest. If there is something good in it we can hold on to it..."156 Another activist and lawyer commenting on personal status codes campaigns said "Cooperation with the men of religion on amending personal status codes is necessary. I can stand in front of an audience and talk, talk, talk to make my case but unless I have religious authority standing by me and agreeing with my case then I can get nowhere. I challenge anyone to say otherwise." ${ }^{\prime 157}$ The presence and authority of the confessional structure is undeniable and is innate to the Lebanese context. Feminist agents pushing forth gender equality norms must acknowledge this context and adjust to its existence as indicated through these examples.

The campaigners of both 13/15 and Women's Right to Marriage and Divorce in Sunni Islam thus asked for reform that does not target rules which are considered divinely inscribed. The same activist and lawyer made it clear that "there are issues bound by Shari'a that cannot be addressed because of their divine nature, like the inheritance laws

\footnotetext{
${ }^{156}$ Interview 8

${ }^{157}$ Interview 7
} 
but issues such as custody and alimony can be addressed." ${ }^{\text {158 }}$ The Campaign 13/15 has tried to bolster its position by leaning on the amendments to personal status codes in the Arab region. The campaign folder circulated to all confessional leaders by the Network for the Rights of the Family included amendments to child custody laws approved by clerics in Arab countries like Kuwait and Libya. In the Women's Right to Marriage and Divorce in Sunni Islam campaign adjusting to the filter translated into an educational effort. Feminist agents decided that where laws cannot be amended immediately and where people are still marrying primarily through religious institutions women must be informed and armed with what rights their religion provides for them. A booklet produced by the campaign emphasized that the study of women's rights must be rid of "preconceived ideas and customs that generally have nothing to do with essential principles of religion. Religion does not discriminate between persons. It calls for love and rejects any forms of hate." ${ }^{159}$ The booklet goes on to define discrimination against women and ties it to marriage and divorce. It advocates for the use of scholarly guidance and rulings of the Shari'a that are free of the "male chauvinistic culture of society". This in-line with the divine filter does not operate by itself. Those that are using the international conventions to support their demands for equality in women's status in marriage have translated the norm for equal treatment in the family by remaining in line with the divine without criticizing but pointing out the current conditions of inequality found in Lebanese religious courts. This translation has transformed the norm to

\footnotetext{
${ }^{158}$ Ibid
}

${ }^{159}$ Fatmeh Kaddourah, Lamia Rustum Shehadeh, and Aman Kabbara Chaarani, "Women's Rights in Marriage and Divorce in Islam", Committee for the Follow Up of Women's Issues, Lebanon 
complement the confessional structure. Effectively, however, this also has muted certain characteristics of the norm. It has changed the norm by addressing the aspects of gender equality in family and marriage by educating women on their rights provided in the writing of a marriage contract but without demanding for changes in the inequality of inheritance laws existent in Islamic law.

\section{The Geopolitical Filter}

The global landscape has changed over the years and the capability to cross boundaries and interface with others around the world has reverberated in many ways on the local landscape. Lebanon is no exception and regional and global currents have taken shape in multiple layers including in the filtering of women's rights norms. There are two arguments that produce a geopolitical filter. First, there is the argument that norms of gender equality are Western and imperially imposed, and thus need to be resisted. The second argument appears as an ideological debate within the women's movement that opposes secular and religious values. Both these arguments have been made within the debate of the universal versus the cultural character of human rights law. In the campaigns they are reflected in the relationship between women's non-governmental organizations and foreign donors who provide almost all of the funding for women's rights campaigns. The fact that women's rights projects are almost entirely funded by foreign and mostly Western organizations fuels these arguments and supports the filter.

When I questioned a long time activist and human rights worker about the influence of the West or foreign donors on the choice of local non-governmental organizations to campaign around issues like the "Women's Right to Marriage and 
Divorce in Sunni Islam", she said "yes it is an issue" because cultural relativists who oppose the implementation of women's rights norms "hold onto it for example in Egypt to resist change, they hold that issue like a sword and say you guys are bringing in your funding from outside, that means they impose on you and they own you. It doesn't work that way exactly." Using international conventions and declarations adopted by the state as a source of support in women's organizations' demands is only a strategy to reinforce what the state has already agreed upon. ${ }^{160}$

The rise of Islamic feminism in the Middle East can be explained as a response to arguments that oppose East vs. West, you are with us or against us, and the years of political history that accompany this. One of my interviewees described the rise in Islamic feminism as a result of the international women's movement and as a reaction to Western imposition. This cultural relativist argument translates gender equality norms through a geopolitical filter. The interviewee claimed that Islamic feminism is indigenous and does not need to rely on the Convention to Eliminate all Forms of Discrimination against Women thereby providing a religious discourse that works outside of the international forum. She cited the example of Jinan University in Lebanon's North that provided its constituents with an alternative to international agreements by referring to the rights afforded within religion. She went on to say

"That their point was to get out from under international agreements specifically CEDAW as a starting point and to remain within the religious sphere by showing that those rights are already provided for in Islam. This Islamic discourse is in reaction to and utilizes the civil discourse that is dependent on international

\footnotetext{
${ }^{160}$ Interview 18
} 
agreement but is removed from the international movement. So what you have is

a forum that looks like the founding fathers not the civil society." ${ }^{161}$

She recounted the difficulties faced when trying to collaborate with faith based organizations. They refuse to be considered as active members of civil society because of their authoritative source. ${ }^{162}$ On the other hand, an interviewee working on the role of women in Islamist organizations asked whether women's organizations had even approached the Islamist feminist organization of Hizballah per se. She also asked whether the omission was a matter of ignorance or deliberate. ${ }^{163}$ The geopolitical filter has caused the translation of gender equality norms outside of the international forum thereby changing the norm itself and resulting in simultaneous translations.

Feminist agents have managed to reconcile their internal and external understanding of these international gender equality norms in a way that allows them to retain their personal beliefs while at the same time translating the international norm that can be understood and accepted at the local level. When questioned about Western influence or the argument made by some about the Western imposition of women's rights, a member of the Committee for the Follow Up of Women's Issues responded by saying that not all donors are European countries and that the UN community plays a role in funding gender programs. "That means I cannot say that everything that requires change is because the West wants it. For example The Beirut Campaign [Women's Rights to Marriage and Divorce in Islam campaign], the West wants to tell me to go and

\footnotetext{
${ }^{161}$ Interview 18

${ }^{162}$ Interview 19

${ }^{163}$ Interview 16
} 
get divorced, my religion tells me that this marriage is a contract between a woman and a man, where a woman puts into it all her demands. I am applying what came in my religion so that I can protect myself and my children." ${ }^{164}$ This statement falls outside of the international discourse on gender equality which she relies on. It forces her to use an Islamic feminist translation that seems to be more in line with her own subject position when she confronts the geopolitical filter.

\section{Conclusion}

International norms of gender equality as established by the Convention on the Elimination of All Forms of Discrimination Against Women are intended to be implemented at the state level with relative ease as they are adaptable to any type of existent local structure. However, the filters that reveal themselves in the case of the struggle for equality in personal status codes are an indication that gender issues are inextricably tied to political, geo-political, and structural conditions that shape gender reform proposals.

Campaign 13/15 as well as in the Women's Rights in Marriage and Divorce in Islam Campaign both have to navigate filters that influence the shape of international norms. Campaign 13/15 inspired by the tenets of CEDAW and the principles of the equal status of women in marriage found itself defined by the contours of confessional patriarchal laws. The translation of CEDAW norms appears in the form of child custody arrangements and laws because they are not defined by divinely inscribed and unchallengeable religious forums. The Women's Rights in Marriage and Divorce in

\footnotetext{
${ }^{164}$ Interview 18
} 
Islam Campaign seeks a translation of article 16 without asking for reform or a uniform law but by empowering women at the mass level and arming them with their rights within the religious tenets. The campaign changes the norm through the geopolitical filter asserting its cultural and local nascence by leaning on the tenets of the family as the basic unit structure of society and juxtaposed to Western reflections of individualism and the facilitation of divorce. While the CEDAW committee might insist that Lebanon remove its reservations and institute a uniform personal status code to be in line with its commitment to CEDAW and to have faithfully translated the international norm at the domestic level, this work shows that a diffusion of the international norms outlined by article 16 of CEDAW is translated through filters co-produced by women's organizations and campaigns operating in the context of state, social, and international structures. In this process of implementation the norms translated are transformed because the demands for reform fall short of gender equality norms. Reforms demanding gender equality in custody remain incongruent to the principles by continuing to make a distinction in age reform based on male and female requirements. Informing women of their rights in marriage and divorce does not afford them equal standing with their male partners. 


\section{$\underline{\text { Chapter } 5}$}

\section{Campaigns for Gender Equality Norms in Nationality Law}

After twenty years of living in Lebanon, a Sudanese man received his deportation papers. This might not be unusual for an illegal immigrant anywhere in the world, but what is unusual is that the man had married a Lebanese woman and had two children with her. The Lebanese woman was not able to confer her nationality on her husband and her children. The family sought help from the campaign called "My Nationality My Right and the Right of my Family". I interviewed the organization in charge of coordinating the campaign in their offices and they gave me this case as an example of the repercussions of Lebanon's discriminatory nationality law. "There are countries that give citizenship based on residency (tie to the land) not only on blood relationship. But to deny me the nationality based on my ties to the land and also my blood ties ...!"”165

Lebanon's nationality law dates back to 1925 . An inherited law from the French Mandate period it recognizes the passing on of nationality only through the blood of the father. Therefore a Lebanese woman married to a foreigner can never pass on her nationality to her husband or to their children. On the other hand the nationality law allows for a Lebanese man to pass on his nationality to his foreign wife, and his children are born Lebanese. The women's movement in Lebanon has long struggled to amend the nationality law with no success. The reason cited by lawyers and public officials alike that makes Lebanon's nationality law so intractable is the " $300,000-400,000$ Palestinians on the ground, who want to marry Lebanese women so that they can get the

\footnotetext{
${ }^{165}$ Interview 4
} 
citizenship." ${ }^{, 166}$ However research conducted by the Committee on the Follow Up of Women's Issues and the Collective Research for Training and Development Action found that the majority of registered Lebanese women married to foreign men are not married to Palestinians. According to an interview with the Committee the obstacles and opposition encountered in attempting to amend the nationality law are based solely on a patriarchal mentality. ${ }^{167}$

Citizenship entails the set of legal processes that define who belongs to the state. It sets out the rules that define the obligations and rights of the people. ${ }^{168}$ The concept of nationality must not be confused with citizenship. Citizenship encompasses a broader notion with nationality being a small part of it. The international women's movement has been combating gendered constructions of state and nation where women have always been treated as less than whole citizens. Relegated to the private sphere and based on the idea that they acquire their public rights through the relationships they have with their fathers and then husbands, women have historically been stripped of their nationality when marrying foreigners. One of the consequences of these biased laws was that women were rendered stateless in several cases. It was not until the 1950s that states began to reverse this inequality. ${ }^{169}$ Article 15 of the 1948 Universal Declaration on Human Rights set the standards for the rights of individuals where nationality is

\footnotetext{
${ }^{166}$ Interview 18

${ }^{167}$ Interview 18

${ }^{168}$ Suad Joseph, "Gender and Citizenship in the Arab World, Mediterranean Development Forum, UNDP: 2002

${ }^{169}$ Bredbenner, Candice L. A Nationality of Her Own: Women, Marriage, and the Law of Citizenship. Berkeley and London: University of California Press, 1998
} 
concerned: "Everyone has the right to a nationality; No one shall be arbitrarily deprived of his [sic] nationality nor denied the right to change his nationality.” The 1957 Convention on the Nationality of Married Women clarified that this right also applied to women and codified that women's right to nationality must not be dependent on her spouse. This move brought the women's movement a step closer to establishing themselves as full citizens. The right to equality in nationality is emblematic of Cynthia Enloe's contention that the "personal is political" and in turn the personal is international. ${ }^{170}$ This proves to be especially true where women's rights are concerned. International norms on gender equality in nationality solidified themselves as part of the global gender equality regime with the Convention on the Elimination of all Forms of Discrimination against Women which in article 9 extends women's nationality rights to include the right to pass on their nationality to their children.

Lebanon signed the Convention on the Elimination of all Forms of Discrimination Against Women in 1996 but placed reservations Article 9 paragraph 2 of the convention that refers to the rights of women in passing on their nationality. The Beijing conference on women helped establish the National Commission of Lebanese Women and created Lebanon's first national strategy aimed at addressing women's equality. Activists that have worked on the nationality law in Lebanon find that it is also inextricably tied to the status of women in marriage and the family and that headway will only be made when the reservations are lifted on both the articles.

\footnotetext{
${ }^{170}$ Enloe, Cynthia Bananas, Beaches and Bases: Making Feminist Sense of International Politics $2^{\text {nd }}$ edition; Los Angeles: University of California Press, 2000
} 
This chapter explores how the global gender nationality norm is translated within the complex socio-political context of Lebanon by examining the campaigns to amend Lebanon's nationality law. The first section traces the concept of nationality as it has been constituted in Lebanon's legal and social structures. The second section outlines Lebanon's contemporary campaigns targeting the nationality law and identifies the filters that operate within the campaigns.

Nationality in Lebanon

One must understand the concept of citizenship and its structure within Lebanon's specific context to trace gender inequality in Lebanon's citizenship laws. Joseph suggests that although citizenship as a concept is challenged she finds Turner's formulation of the notion, as a set of practices (juridical, political, economic, and cultural) which define a person as a competent member of society, and which as a consequence shape the flow of resources to persons and social groups", to be most fitting. ${ }^{171}$ The creation of citizenship laws are a derivative of what Rogers M. Smith argues are civic myths. ${ }^{172}$ Smith considers civic myths to be "used to explain why persons form a people, usually indicating how a political community originated, who is eligible for membership, who is not and why, and

\footnotetext{
${ }^{171}$ Joseph, Suad ed. Gender and Citizenship in the Middle East, Syracuse, NY Syracuse University Press: 2000: 107

${ }^{172}$ Rogers M. Smith Civic Ideals: Conflicting Visions of Citizenship in U.S. History. New Haven, CT : Yale University Press, 1997
} 
what the community's values and aims are". ${ }^{173}$ Joseph also adds that there can be several civic myths that operate at the same time. ${ }^{174}$

Constructing citizenship in Lebanon involves kinship ties as a fundamental variable that defines a member of its society. "Kin groups create imagined communities upheld by the power of 'nature', usually sanctified by the authority of God, and, in weak states such as Lebanon, often assimilated into and institutionalized by the laws and practices of citizenship". ${ }^{175}$ The other fundamental variable included in Joseph's analysis is sectarian pluralism. Kinship and sectarian pluralism are inherently patriarchal and patrilineal while inextricably tied to family laws and children's rights. "Citizens have to belong to a male-defined kin group to belong to a religious sect, to belong to the nation, and to acquire the rights and responsibilities of citizenship. Children are assigned both the religious and political identities of their fathers. By not allowing women to pass citizenship on to their children (or their spouses), most Arab states cement the linkage between religious identity, political identity, patrilineality, and patriarchy - that is, between religion, nation, state, and kinship". ${ }^{176}$

Lebanon's nationality law of 1925 was based on French nationality laws of the nineteenth century. The law has been amended two times in 1939 and 1960. As it is in

\footnotetext{
${ }^{173}$ Rogers M. Smith, Civic Ideals: Conflicting Visions of Citizenship in U.S. History. New Haven, CT : Yale University Press, 1997: 33

174 Joseph, Suad ed. Gender and Citizenship in the Middle East, Syracuse, NY Syracuse University Press: 2000

${ }^{175}$ Ibid 109

${ }^{176}$ Regional Bureau for Arab States United Nations Development Programme, Women are citizens too: The Laws of the State, the Lives of Women, 2002
} 
many of the Arab and Middle Eastern states individuals can only acquire Lebanese citizenship through jus sanguinis (i.e. by blood) and only through the father. Lebanese women married to foreign men cannot naturalize their husbands or pass on their nationality to their children. On the other hand children of a Lebanese father are upon birth recognized as Lebanese and the foreign wife of a Lebanese man can acquire citizenship after a year of the marriage being registered with the state. In the event of the death of a husband naturalized wives can also acquire Lebanese nationality for their children. Thus, the law not only discriminates between men and women in Lebanon but also puts Lebanese women at a disadvantage compared to foreign women that are naturalized from marriage to a Lebanese man.

Campaigns on Nationality Laws

Citizenship rights are directly tied to kinship and patriarchal conceptions. Proportional representation and the delicate confessional balance have politicized translating women's right to nationality. Attempts at tackling gender equality in Lebanon have been interrupted and imbued by political stand offs and confrontations. Tracing the development of women's organizations struggle to achieve gender equality and how both internal and external crises swayed their movement is an important process to understand the development of contemporary nationality campaigns.

The first campaign to gain momentum on reforming Lebanon's nationality law was started in 1992 by the Lebanese Association for Human Rights along with several women's groups. The goal was to amend the nationality law to give Lebanese women married to foreigners the right to pass on their citizenship to their children in the event of their husband's death. The recommended amendments were presented to the Minister of 
Justice on the basis that the demand is a matter of justice and equality and in the interest of family preservation and the interests of the child. While the campaign resulted in the formation of a ministerial committee to study the case it did not result in any change. ${ }^{177}$ However, since then women's organizations have chosen to carry on the work of the Lebanese Association for Human Rights and have launched several campaigns continuing to demand a change in legislation on nationality.

My Nationality is My Right and the Right of My Family

Collective Research and Training on Development Action (CRTD-A) in collaboration with several women's organizations in Lebanon launched the campaign My Nationality is My Right and the Right of my Family in 2002 as part of a regional campaign to amend the nationality laws of seven Arab countries in the Middle East and North Africa Lebanon, Syria, Jordan, Bahrain, Egypt, Tunisia, and Morocco. Supported by the UNDP and the Women's Learning Partnership organization the campaign aims to raise awareness about the gendered inequality in nationality laws and to push the countries to reform their laws and remove the reservations to Article 9 paragraph 2 of the Convention on the Elimination of all Forms of Discrimination against Women. While the campaign was a regional one with one goal, it was understood that each country's context would vary and activists in each country would have to deal with diverse local complexities attached to the issue. CRTD-A, coordinated its activities with local women's organizations and networks in Lebanon in a way to broaden its lobbying and activities scope. Some of the other organizations included in this campaign were the

\footnotetext{
${ }^{177}$ Regional Bureau for Arab States United Nations Development Programme, "Women are citizens too: The Laws of the State, the Lives of Women”, 2002
} 
Lebanese Women's Network, Lebanese Women's Democratic Gathering, KAFAEnough Violence and Exploitation, and the Committee for the Follow up of Women's Issues. The campaign's activities included community awareness sessions, statistical research on Lebanese women married to foreigners registered with the state, preparing a proposal for reform, lobbying the parliamentarians, and holding press conferences. In the process the campaign was able to deduce from the statistics that a majority of the Lebanese women married to foreigners were married to Iraqis. The other registered marriages included some to Germans, Palestinians, Egyptians, among others. These results were presented to Parliamentarians in the hopes of erasing the myth of Palestinian naturalization as a result of amending the nationality law. Parliament and the Council of Ministers are still reviewing the draft proposal for amendment. After the political crisis following the assassination of Prime Minister Rafik Hariri in 2005 and the political fallout that resulted in the suspension of all parliamentarian meetings, the campaign altered its strategy and decided to target the court system on a case by case basis challenging the nationality law. The campaign is ongoing.

\section{Lebanese Women's Rights and the Nationality Law}

Committee for the Follow Up on Women's Issues (will be referred to as Committee from here on) a partner in the CRTD-A campaign My Nationality is My Right and the Right of My Family launched activities in the South and North of Lebanon funded by USAID and the Dutch Embassy. The campaign activities took place in November 2007. The results of the campaign led to their funding by the UNDP in 2008 of a new campaign titled "Lebanese Women's Rights and the Nationality Law;" the Committee became the principal coordinator of this campaign. This campaign became 
controversial and created friction between the Committee and the Collective Research and Training on Development Action the original campaign coordinator. At the UN meeting to announce the campaign and to get the cooperation of the other organizations that had been working on the campaign with CRTD-A, CRTD-A refused to take part saying that its campaign is still ongoing. The campaign parallels the events and activities of its predecessor with awareness sessions, lobbying parliamentarians, statistical research studies, and draft proposals for the amendment of the law, accompanied by press conferences and other advertising needed. Most of the collaborators from the My Nationality is My Right and the Right of My Family have agreed to work with the Committee on this campaign. The campaign funded in April 2008 is scheduled to end in 2009.

Feminist Agents Interests and Identities:

Western funding and competition for access to it has some people asking whether activists are committed to the cause or committed to the funds? The number of NGOs in Lebanon has grown so quickly that they have become quite splintered. That coupled with the culture of competition amongst women organizations and the need for money to survive has created a negative atmosphere with the repercussion being progress on lobbying effectively for change. ${ }^{178}$ Activist and coordinator of the nationality rights campaign in describing Lebanon's campaign denounced the women's movement by saying "A women's movement in Lebanon is non-existent. And that you can quote me on. Yes it is an announcement and a grave one at that but you have to believe me

\footnotetext{
${ }^{178}$ Karns Margaret P. and Karen Mingst, International Organizations: The Politics and Processes of Global Governance, Boulder and London: Lynne Reiner Publishers, 2004
} 
(accept). There are women's organizations that are working on various issues that have a large effect on whatever they are working on but maybe the effect would be even greater if they worked together (collaborated), it would be greater when there is a unification on an issue, and it would even be greater and more effective when there is not this competitive feeling and this commitment to the donor's agenda." ${ }^{179}$ My meeting with her took place the day after UNDP-Lebanon had announced that it was funding one of the members of the nationality rights campaign to coordinate a new campaign aimed at achieving the same goals. Several of the partner members in the CRTD-A campaign voiced their concern over this development. One activist exclaimed, "Well how is this women's movement going to... make some kind of internal change... Everyone got together and they said well this is something that is still in the works; why are we going to start all over again. Almost identical, if we are going to repeat the issue in the same places then this would be a waste of time... If the CRTD-A campaign has not concluded here and we want to continue with one over there, you understand this makes for confusion and loss of the issue at hand." ${ }^{180}$

The international structure and questions of international funding have had an effect on the translation of the gender equality norm on nationality in two ways. First, it has created a rift in the movement and created a sense of competition that has taken the focus away from the cause making you question whether the norm itself is of importance. Even the campaign coordinator believes that the success of the Algerian nationality

\footnotetext{
${ }^{179}$ Interview 4

${ }^{180}$ Interview 6
} 
campaign, where the nationality law was reformed to give women the right to pass on their nationality to husband and children and where the constitution was amended to allow for non-Muslim men to become citizens, could be the result of a strong women's movement.

-"The reason for this success has to do with the campaign but I believe in large part is more because of the women's movement in Algeria, the women's movement of Algeria had been working for 20 years on the Personal Status Codes. So the amendment of the nationality law came as part of a reform project for many personal status codes. So firstly you can say that there was a consensus in the Algerian women's movement on a single issue that we hope to see over here... Maybe they found success because of the absence of funding maybe if there is no funding the issue is what drives us and not the foreign funding that sets the agenda. That is how it happened the reform in Algeria was an excellent example set." ${ }^{\text {181 }}$

For this activist the funding provided by international donors somehow dilutes the translation of the norm by driving a wedge in the movement. So where the lack of funding exists activists are driven by the issue at hand and the goal is clear. International funders might have a different set of goals increasing the chances of multiple organizations competing for those projects and taking out the element of commitment to the cause.

At the beginning of the CRTD-A campaign when the call was put out to the women's organizations to coordinate and collaborate on seeking reform for the nationality law several organizations came forward. As they put forth their demands one of the organizations decided that they wanted to pull out. According to one of the collaborators she thought that their wanting to work by themselves was fine but "they started organizing their own events only to realize that their project was about acquiring

${ }^{181}$ Interview 4 
nationality rights for the children while our project is a family project that emphasized the right to nationality for husband and children." 182 To her this posed two problems, one which was a logistical concern that was about lobbying parliamentarians with two sets of demands one less than the other. The second issue for her was that "When you are to ask for a right, ask for the whole gamut and whatever they want to give you is fine, you will continue working on the rest. You don't immediately succumb to the less than route. Do not accept less than what you are entitled to, because I will not accept to be half a citizen, or a quarter, or three quarters." ${ }^{183}$ The two concurrent demands on nationality reform that appeared as a result of the split with those seeking only to pass on the nationality to the children driven by a need to seek recognition and success on the matter knowing that lawmakers are more likely to reform incrementally as opposed to a huge upset. However, this translation is not in line with achieving of gender equality as a whole but rather reformulating the equation and changing the norm in the process.

Another activist claims this split within the movement is rather a "problem that happens when there is no real collaboration and when you do not have one goal: the goal is that this is a woman's right; and that right cannot be negotiated or bargained... That means you can't divide my rights and give me pieces from here and there. If I accept that then I am not respecting myself and I do not believe that this is part of my right.” This activist cannot define the root of the problem but extrapolates that "it is due to lack of clarity on the goal, and lack of unity on the goal... lack of understanding of the problem,

\footnotetext{
${ }^{182}$ Interview 8

${ }^{183} \mathrm{Ibid}$
} 
and lack of cooperation between organizations." ${ }^{184}$ But again this translation of the norm by feminist agents and their interests and identities transforms the norm of gender equality on nationality based not on principle but a different understanding of the principles, rules, and structure.

As in the other campaigns described in this dissertation, the nationality campaigns produced powerful filters that affected the translation of international gender equality norms into the Lebanese context. Some of these filters resemble those of other campaigns others are specific to this campaign. Geopolitical and confessional filters as well as the family preservation filter have appeared in other campaigns. A culture of belonging filter emerges as a new one in the nationality campaign. I will review each in turn.

Confessional-Political Filter

Lebanon's reservation to article 9 paragraph 2 of CEDAW is based on the fear of naturalizing the 300,000 to 400,000 Palestinian refugees within the country's borders. Geopolitical events have created an international structure that produces a sense of fear and animosity towards the Palestinian refugee community within Lebanon. This fear is tied to the delicate proportional confessional structure of the state. With no formal census taken since 1932, i.e. prior to the country's independence, and with a large migratory population of mostly the Christian sects the country's demographic composition has changed drastically. Estimates are that the Lebanese Christians have become a minority that constitutes approximately 30-40 percent of the population, and while the Sunni Muslims at one point were considered the majority of minorities they

\footnotetext{
${ }^{184}$ Interview 7
} 
have been overtaken by a fast growing Shi'a population. With a majority of the Palestinian refugees being of Sunni descent their naturalization could swing in favor of the Sunni Muslim community and affect the relative power of others. Used by political groups as leverage, the issue of naturalizing Palestinians has polarized the country along sectarian lines. ${ }^{185}$ However there seems to be an inconsistency in the fear produced by the Palestinian refugee community as the resistance to amending the nationality law reflects a fear about naturalizing Palestinian men but does not discuss the naturalization of Palestinian women who are by law given access to citizenship upon marriage to a Lebanese man.

Dealing with the Palestinian question has produced a confessional filter, rooted in the country's geopolitics, translating the gender equality norm of nationality. Searching for routes to translate this norm, activists have taken their case to the legislative institutions and argued that the nationality law is in violation of Lebanon's constitution which guarantees women's equality. Furthermore, they have argued that the law violates the Rights of the Child Convention which stipulates that all children are entitled to a nationality, which Lebanon has ratified with no reservations. However, the activists found themselves in a situation where parliamentarians discussed reforming the law partially, excluding Palestinians from naturalization. According to Lina Abou Habib, executive director of the Collective Research for Training and Development Action organization, negotiating the right to full citizenship is not a condition gender equality

\footnotetext{
${ }^{185} \mathrm{http}: / /$ www.dailystar.com.lb/article.asp?edition_id=1\&categ_id=31\&article_id=108455 http://www.pomed.org/docs/Lebanon_Backgrounder.pdf
} 
activists are interested in. ${ }^{186}$ With activists refusing to negotiate the rights of women translating this international norm has come in direct conflict with the confessional political filter. Parliamentarians in the recent cabinet meeting refused to put the question of nationality reform on the agenda to the disappointment of the Minister of Interior who claims that out of 30 Ministers two of which were women most decided against the inclusion of nationality reform on their agenda, once again showing that matters of gender equality are not a top priority in public affairs. ${ }^{187}$

According to the Lebanese reservation to Article 9 and the principles of the Arab League the Palestinians are to remain refugees in order for them to pursue their right of return or right for reparation. The Palestinian question in Lebanon is a very delicate one because they are the largest Palestinian refugee group in the Middle East and because they have been injected as part of the Lebanese civil and political conflict.

Agents have combated this filter by translating the nationality gender norm and using the Convention on the Rights of the Child on a case by case basis. This activist and lawyer "received a call from two women, sisters they were married to men that had no papers because they were born in Lebanon but did not have the nationality. Both women have children and they have no nationality, because they cannot get their mothers and their fathers have none to give." She goes on to claim that "This case is an easy case to

\footnotetext{
${ }^{186}$ Mahdawi, Dalila, "Activists press Cabinet to work toward granting women nationality rights", Daily Star Magazine November 26, 2009 http://www.dailystar.com.lb/article.asp?edition_id=1\&categ_id=1\&article_id=109121

${ }^{187}$ Mahdawi, Dalila, "Ministerial statement fails to address nationality law", Daily Star Magazine November 21, 2009
} 
win because of international law and the convention on the rights of the child that Lebanon has signed with no reservations." ${ }^{\text {188 }}$ Addressing the state structure in the court system this activist and lawyer will argue that the state is violating its commitment to the children's rights convention by keeping children stateless. Another lawyer and activist reaffirmed this position by adding that "Within the constitution there is an article that says you have the right to address the court if you believe that your rights have been violated in accordance to an international convention or treaty signed by the nation. But not many people know about this article." ${ }^{189}$ This translation has metamorphosed the gender equality norm and broadened it to inextricably tie children's rights to the gender equality regime. Scholars and activists have begun to realize the power of local laws and understanding how to make arguments relevant to effect change even if the change is incremental. According to Marsha Freeman "Women's rights begin at home". ${ }^{190}$

'The recent political instability and culture of violence has brought with it the realization that mobilizing the social community is an alternative strategy for the campaign. Campaign coordinators decided to network with other civil society organizations which also led to cooperation with bordering countries. They opened a unit to specialize in gathering legal information and opening case files. When she reflects on how they set this up she points to

\footnotetext{
${ }^{188}$ Interview 8

${ }^{189}$ Interview 19

${ }^{190}$ Freeman, Marsha A. "Women, Law, and Land at the Local Level: Claiming Women's Human Rights in Domestic Legal Systems" Human Rights Quarterly, Vol. 16, No. 3 (Aug., 1994), pp. $559-575$
} 
"the area of Bourj Hammoud, Al Naba'a and Sin El Fil, that has a diverse population, diverse religious community and is plagued by economic hardship because it is on the outskirts of the city. This is the largest number of people that economically cannot help themselves....We find these cases not through direct contact but through the social services and other providers that work with them. There are social service security organizations that provide them with welfare services they can direct us to cases that we can help... they can still provide the social services they are equipped with and we can handle the legal aspects... this takes us back to the regional condition and network. When we have woman whose Syrian husband has passed on and she doesn't have the mobility to take care we coordinate and collaborate with our partners in Syria their lawyers in the municipalities help facilitate our case." 191

Translating the gender equality norm on nationality against a culture of violence and political instability has had women's organizations seeking support of networks both within a state, social, and international structure.

Refusing to give in to the current stalemate women's organizations are reaching out to find alternative ways to collaborate and coordinate on campaigns, keeping the momentum alive through the use of internet, email, phones, and letters. Translating gender equality norms have come up against the confessional political filter where historically political instability has prevented the norm from finding its way on to the agenda. However, women's organizations today have realized that there are alternative strategies to be used and that the process of translating these norms can continue on while the target of the campaign can change.

Culture of Belonging Filter

In one of my interviews I raised the question of women's campaigns on nationality reform and the existence of parallel campaigns with some demanding the law to include only the right to pass on the nationality to children while others saw the issue

\footnotetext{
${ }^{191}$ Interview 4
} 
as a right to pass on the nationality to both husband and children. This divide is a reflection of the culture of belonging filter that has some women activists translating the international norm without negotiating it against the filter, while others succumb to the filter and produce 'faithless translations'. My interviewee's response was a reflection on the status of belonging. Clearly stating that "what you find is on a general level you find that there are even foreign women that are not convinced that a woman should be able to give her children the right to nationality, this is the social understanding. They fear that women from neighboring countries will begin to pass on their nationality to their children and start to fret that now our children will be Syrian, Jordanian, etc. It is taking on the political facets and the consequences that spread into the social mentality." 192 Why is it that the idea that Lebanese women alone are not valued as able to pass on the national identity to their children?

Social structures and the culture of belonging filter have blurred the basis of the gender equality nationality norm translating it into competing visions of the norm, one flowing from the patriarchal kinship intractable paradigm, and the other flowing from the global gender equality regime. This in effect has agents' identities and interests metamorphose the gender equality norm. In Lebanon there is a pervasive culture of belonging, and the strength of kinship is crucial in defining and structuring who belongs and who does not and belonging is traced through the male. Joseph outlines the kin care control paradigm, which allows the state through institutionalized family law to control

\footnotetext{
${ }^{192}$ Interview 6
} 
both males and females. ${ }^{193}$ The laws reinforce kin control and society uses it as a way to define its boundaries.

Lina Abou Habib in an interview on the regional campaign to reform nationality laws in the Arab world describes how women's organizations early on realized that initiating the campaign required time and a variegated focus. Focusing on the consequences of biased nationality laws on the lives of the very women experiencing the repercussions became fundamental. On the ground work was pivotal to enlighten societies of the far reaching effects of nationality laws that only recognize the full citizenship of men. ${ }^{194}$ In 2006 CRTD-A and another organization began to see the value in utilizing another approach that speaks to the conditions of those suffering.

-It was no longer the organizational type of campaigning. Then there was another organization that started with the same name My Right is the Right of my Family that decided to put files together of legal applications from their members and present them to the system. This idea was about putting those who are the ones struggling in charge and we would just support and sponsor them. The last folder put together by one of the women involved -- she gave me her picture and her documents to send it to the Ministry of the Interior -- was on 12 of July 2006 ( $1^{\text {st }}$ day of the 34 day war between Lebanon and Israel), and her papers like her birth certificate remained with me a long time and then I returned the papers in case she needed to use them. ${ }^{195}$

This approach was about empowering women on the ground to take responsibility and charge of their own fate, as the activist put it "We can only talk on their behalf from a rights platform; they can speak from a living condition." Translating this gender equality

\footnotetext{
${ }^{193}$ Joseph, Suad. Civil Myths, Citizenship, and Gender in Lebanon. In Suad Joseph, (ed.) Gender and Citizenship in the Middle East. Syracuse: Syracuse University Press. Pp 107-136.

${ }^{194}$ Workman, Anna "Interview with Lina Abou-Habib, Director of Collective for Research and Training on Development-Action (CRTD-A) in Lebanon”, Women's Learning Partnership, March 4, 2006. http://www.learningpartnership.org/citizenship/2006/08/lahinterview030406/

${ }^{195}$ Interview 4
} 
norm on nationality has taken a participatory approach that counts on empowering women at the local level in the hopes of garnering mass support and a feeling of a homegrown movement that is relevant to the social context of Lebanon. This approach is part of the latest development theories of the 1990s and the inclusion of a focus on gender development as a necessary stage in the development of Southern states. ${ }^{196}$

Recent legal developments point to a redefining of these boundaries of belonging. In a landmark ruling on a nationality case brought forward by a Lebanese widowed mother who was married to an Egyptian three judges ruled that her four children in Lebanon were entitled to the Lebanese citizenship. Their decision was based on what they viewed as a vague nationality law and their reliance on Article 7 of the constitution that clearly states all Lebanese are equal in the eyes of the law. The Judges themselves in the report go on to ask "Is it conceivable that Lebanese law prefers the foreign woman to the Lebanese women? No law can stipulate rights giving more protection to a foreigner than to a national..." ${ }^{197}$ Their decision was written without explicitly using women's equality as a rationale. This decision and the statements within however clearly show that the culture of belonging filter can at times be used to facilitate the translation of gender equality norm on nationality through the state structure and the presence of agents within those institutions. The judges clearly in this case overruled kinship rules in favor of a national sense of belonging. Whereas in the previous section the culture of belonging filter was used to exclude women and strengthen kinship rules

\footnotetext{
${ }^{196}$ Willis, Katie, The Theory and Practice of Development. Routledge Perspectives, 2004

${ }^{197}$ Mahdawi, Dalila, “One woman's fight against Lebanese nationality law”, Daily Star Magazine August 2009
} 
and the social structure in place. By juxtaposing the bias in the law which allows a Lebanese man to pass on his nationality to his spouse within a year of marriage and inherently to his children immediately upon birth the judges have voiced their disappointment in the loss of identity and national sense of belonging a woman's family must endure upon marriage to a foreigner. However, I must note that following the judgment Justice Minister Ibrahim Najjar appealed the ruling leaving those to believe that the confessional political filter seems to confront the culture of belonging, once again having an effect on the translation of the norm.

Family Cohesion Filter

The 1992 Lebanese Association for Human Rights campaign to reform the nationality law discovered that tying the argument to Lebanon's fundamental value of preserving the family unit proved to be useful. ${ }^{198}$ In this case translating the nationality gender norm constructs a family preservation filter that harmonizes with the confessional social structure. Lebanon's coordinator on the nationality campaign provided me with a brief rundown of the reform in nationality laws of the regional campaign members. In 2003, Egypt amended its nationality law but only provided for children to acquire the nationality of their mother. The stipulation was that the law would not work retroactively and that husbands would not enjoy the same rights as their children. The activist maintained that the reform while positive was incomplete and that the stipulations made have resulted in added stress to the family. She tied the protection of women's rights to men's rights and

\footnotetext{
${ }^{198}$ Regional Bureau for Arab States United Nations Development Programme, "Women are citizens too:The Laws of the State, the Lives of Women", 2002
} 
-their families' rights... because their children may be male and they are entitled to the right to education and health, etc. It is a human right and part of a woman's right. Why are you lowering the ceiling of demands? Do you only want to worry about the children, what about the husband who is living in his wife's country? You want him to creep, you want the family to be broken up? There is now a law in France that is based on preserving the unity of the family (preservation of the family). The family is the basis of society, like you want to ask for the children's rights, it is like saying you can leave your wife and your kids and go and work somewhere else, and sometimes he is not leaving of his own free will he is being run out... ${ }^{199}$

The translation of the global gender equality norm on nationality in this context is relying on the family preservation filter making the case for amendment of the nationality law in its entirety, which means to include the women's right to pass on their nationality to both spouse and children. This notion is borne out of the experience of the regional campaign. Lina Abou Habib, executive director of CRTD-A, explains that reforming the law is not enough in itself and that countries like Egypt who have reformed their nationality law with conditions have not solved the problem but have made an important first step. However, the reform should be a complete one that "is accessible to all women, and that there are mechanisms for implementation". ${ }^{200}$

\section{Conclusion}

Translating the international norm on gender equality in nationality is an ongoing process that has women's organizations participating in campaigns confronted by several filters and by feminist identities and interests concerned. The campaigns have had to deal with social, state, and international structures. This chapter has shown how all these

\footnotetext{
${ }^{199}$ Interview 4

${ }^{200}$ Workman, Anna "Interview with Lina Abou-Habib, Director of Collective for Research and Training on Development-Action (CRTD-A) in Lebanon", Women's Learning Partnership, March 4, 2006. http://www.learningpartnership.org/citizenship/2006/08/lahinterview030406/
} 
variables have come to translate the norm and in the process at times result in the change of the norm that produces arguments for partial amendments. However, in this specific case where nationality reform is still in the works I argue that the final translation of the norm is still pending with the production of several filters. The ultimate shape of the norm will be affected by these filters.

Another revelation in the campaigns has been that some filters can facilitate the translation of the norm while at the same can also be used to dilute or change the basic principles of the gender equality regime. For example, the culture of belonging filter attached to kinship structures and the state-social relations that are based on care and control has strengthened the patriarchal and patrilineal social understandings to operationalize fear of the Palestinian refugee community as outsiders. On the other hand the recent ruling on the case of the Lebanese widow married to an Egyptian shed light on the discrimination between Lebanese women and the "foreign" wives naturalized due to marriage with a Lebanese man. In the first case, the culture of belonging filter precluded equality for Lebanese women; in the second case it enabled equality for a Lebanese woman with a foreign-born husband, advancing the principle of equality in nationality.

The division of the women's movement and the competition created by the international structure and funding has impeded success in translating the norm on gender equality in nationality. Success on complete norm implementation is dependent on collaboration, unity, and commitment to the issue and not the funding of donors, as several of the activists pointed out to me. While parallel campaigns can produce increased awareness on the subject broadly on a mass level when you have competing visions it can also result in partial reform and inherently in a narrower definition of the 
gender equality norm. This became the issue for the Nationality is My Right and the Right of my Family Campaign, and also when the UNDP decided to nominate the Committee for the Follow Up of Women's Issues as the campaign coordinator for its Lebanese Women's Rights and the Nationality Law Campaign.

Positive developments have come from the culture of violence and political instability that have redirected nationality campaign efforts. Taking on a more developmental approach with a focus on gender development imbued with participation and empowerment in times of crises the Nationality is My Right and the Right of My Family campaign continued on with its commitment to translating the gender equality norm on nationality by refocusing its efforts on the ground creating networks with civil society and crossing state boundaries to reach out to neighboring countries. It also began to work through legal institutions in a way to advance the gender equality norm of nationality one woman at a time. 


\section{$\underline{\text { Chapter } 6}$}

\section{Conclusion}

This dissertation has explored the translation of international gender equality norms into Lebanon's complex socio-political context. It has treated the process of implementation as one that can result in the metamorphosis of a norm. My examination of feminist campaigns has identified several (agential and structural) variables that become operative in the process of norm translation. As outlined in chapter 2, these variables help bring into being mechanisms that I have called filters. Norm translation entails the activation of filters that bring together elements of domestic social and state (political) structures and an international discourse. As constellations of arguments, filters reflect these structures as well as the strategies of agents.

The purpose of examining the campaigns was to offer a comparative analysis that allows me to identify patterns and variances that become evident in the process. This section is about identifying these patterns and variances and developing inferences about the relationship of norm translation and state, social, and international structures. There are several similarities that have appeared from different vantage points. The following section will look at the similarities and differences deduced from comparing the campaigns. I will conclude with some recommendations and possible directions for future research on norm translation. 
Looking at Structures: State, Social, and International

In the campaigns analyzed, international structures appeared in the form of an East/West discourse and patterns of international funding. The identities and subject positions of feminist agents were defined in relationship to this discourse and patterns, and they played a role in the process of norm translation. The challenge for feminists was to avoid having translations of global gender equality norms framed in dichotomous terms of West versus East, something which not always succeeded. International structures played a significant role in the translation of gender equality in personal status codes campaigns, on women and marriage in Islam, and in combating violence against women campaigns. In the violence against women campaigns and the campaign on women in marriage in Islam feminist activists took an apologetic position where justifying both the campaigns and the anticipated results against a Western conception of violence against women became necessary. In both cases the discussion revolved around the Lebanese social structure being identified by the family as opposed to the West that has experienced a deterioration of the family evidenced by a high rate of divorce. Also becoming evident was the reaction to Orientalist types of arguments against Arab culture, which was defended by pointing out the high rates of violence against women registered in Western countries. Norms combating violence against women come up against filters of family cohesion and family honor, which inhibit strict prohibition of domestic violence and honor killings. Within an international structure that postulates a clash of civilizations, these filters produce translations that transform the norm. Combating violence against women is no longer the main issue; instead what emerges is a West 
symbolized by its high rate of divorce due to the promotion of individual rights as opposed to a Lebanon which values the family as the basic unit of society and where divorce is the symbol of ruining one's household and life.

Domestic structures affected the translations of gender equality norms into the local context in particular through the identities of feminist agents and their subject positions. Agents in specific circumstances found themselves trapped within the social structures they were attempting to change. As Joseph has maintained in her work, women in Lebanon have generally adopted kinship structures and in turn have accepted patriarchy in its authoritative form in that space (Joseph 2000, 136). ${ }^{201}$ This is true for feminist activists as much as women in general, although the former saw themselves fighting to change these kinship structures. One of the results was a split within the movement in particular around the campaign to eliminate discrimination in the penal code and in the nationality reform campaign. The other result was different translations of the norm, including one that created a metamorphosis of the norm. In the national campaign to eliminate discrimination in the penal code, the willingness of some activists to agree to an amendment of the article on honor killings that simply adjusted the clause to include both male and female perpetrators produced a change in the norm by translating the idea of gender equality but not by outlawing violence against women or men which is a fundamental characteristic needed for the achievement of equality. ${ }^{202}$ The existence of the law that provides for leniency of a crime based on the honor of the

\footnotetext{
${ }^{201}$ Suad Joseph, Civil Myths, Citizenship, and Gender in Lebanon. In Suad Joseph, (ed.) Gender and Citizenship in the Middle East. Syracuse: Syracuse University Press. 2000. P. 136

${ }^{202}$ One of my students put it nicely by saying they found equality in violence.
} 
family is in direct contradiction with the international norm to combat violence against women. In the nationality reform campaigns, activists divided on the question of whom in the family a woman should be able to pass her nationality onto and some feminist agents only demanded a partial reform that excluded being able to pass nationality on to a husband. Because of its partial nature this translation produced a similar metamorphosis of the norm as in the campaign to eliminate discrimination against women in the Penal Code. Demanding incremental change reflects the gender equality activists' failure to be driven by fundamental values and being swayed by pragmatic shortsighted solutions. In both the campaign to eliminate discrimination against women in the penal code and in the nationality campaigns feminist interests and identities resulted in accepting incremental changes and a corresponding change of the norm. Honor crimes remain a valid course of action with leniency towards both males and females, and nationality law can be amended partially at the expense of gender equality.

Lebanon's complex power sharing system described as a consociational democracy has proven to be most challenging for feminist agents attempting to establish gender equality norms. This particular political (state) structure mobilizes fear of change and loss of power. This is translated in the results of both the personal status code campaigns and the nationality reform campaigns. In the campaign to implement a uniform civil status code or the civil marriage law the fear of politicians prevents the norm from being translated. The same takes place in the debate on nationality reform where politicians and nationals are mobilized by the same fear. Amending the nationality 
law is translated against a political (state) structure driven by the desire to maintain the status quo.

My argument has not been simply that international and social structures inhibit the implementation of norms. Instead, norms actually may change in the process of translation. In order to understand the direction of such changes, I introduced the concept of filters. Filters are where structures meet the arguments of activists and other political agents. Filters are produced in the process of translation and become mechanisms of norm metamorphosis. The following table summarizes the filters identified in my three case studies and indicates the kinds of outcomes that they produced in the process of translation. 


\begin{tabular}{|c|c|c|}
\hline & Filters & Norm Changes and Outcomes \\
\hline Violence Campaigns & $\begin{array}{l}\text { Family Honor } \\
\text { Family Cohesion }\end{array}$ & $\begin{array}{l}\text { Treating violence against women remains } \\
\text { within the context of preserving the } \\
\text { family thus stopping domestic violence } \\
\text { legislation } \\
\text { Gender equality means honor killings } \\
\text { ascribed equally- legislative amendments } \\
\text { do not eliminate honor killing }\end{array}$ \\
\hline $\begin{array}{l}\text { Personal Status Code } \\
\text { Campaigns }\end{array}$ & $\begin{array}{l}\text { Confessional Political } \\
\text { In Line With the Divine } \\
\text { Geopolitical }\end{array}$ & $\begin{array}{l}\text { Consociational democracy has politicians } \\
\text { fearing of imbalance therefore any } \\
\text { personal status campaigns that can result } \\
\text { in changes to demographic makeup is } \\
\text { blocked. } \\
\text { Geopolitical filter against the international } \\
\text { structure opposes a western versus } \\
\text { cultural and religious versus secular } \\
\text { commitment to gender equality rights. } \\
\text { In Line with the Divine changes the } \\
\text { norms by reconfiguring gender equality } \\
\text { norms in the family }\end{array}$ \\
\hline Nationality Campaigns & $\begin{array}{l}\text { Confessional } \\
\text { Culture of Belonging } \\
\text { Family Cohesion }\end{array}$ & $\begin{array}{l}\text { Confessional filter changes the norm of } \\
\text { gender equality to partial implementation. } \\
\text { Culture of belonging attached to accepted } \\
\text { kinship structures that define the } \\
\text { boundaries of national belonging } \\
\text { translates gender equality norms and } \\
\text { redefines these boundaries through local } \\
\text { legislative institutions } \\
\text { Family cohesion is used to facilitate } \\
\text { translating gender equality nationality } \\
\text { norm }\end{array}$ \\
\hline
\end{tabular}


Filters: Family Cohesion, Family Honor, Geopolitical, Confessional Political, Culture of Belonging, and In Line with the Divine

As previously mentioned filters are constellations of arguments activated by structures and agents identities and interests. Below, I briefly provide a detailed description of the various filters activated in the study of these campaigns followed by the outcomes that are produced by the filters.

The family honor filter, where women are the caretakers and representative of this honor, is produced by the interaction of Lebanon's social structure and the identities of agents. This structure is defined by patriarchal norms and rules based on an age and kinship hierarchical ordering that both women in general and agents have adopted. The family honor filter argues that men as protectors and providers for women must be responsible for preserving their honor. The state has accepted this argument and codified it in the legal penal code i.e. by allowing for leniency in crimes of honor. The filter has served to translate norms on violence against women in a way that mitigates against interventions that have been effective in other cultural contexts. The campaigns translating global gender equality norms have targeted the state and society in an attempt to challenge these structures.

Family cohesion filters activated against the social structure argues that wives and mothers are responsible for the preservation of the family. They are the protectors of the home and must manage the relationships within. Deeply embedded in this kinship structure dealing with violence within the home becomes difficult because of the sense of guilt associated with the inability to manage the relationship in the household. The state 
also upholds this structure with the application of welfare or therapeutic models as evidence of its control. The same filter has had different effects depending on the gender equality norm in question. For example, women activists have used the family cohesion filter to facilitate translating the equality norm in the nationality law and support a reform of the law in line with Lebanon's understanding of the fundamental value of the family as the core unit of society. In contrast, in the case of translating the violence against women norm, the family cohesion filter transformed the norm in a way that contradicted equality, favoring maintaining the family unit at all costs and creating parallel discourses within the campaigns on the ways of resolving domestic violence. Finding themselves once again stuck within their own subject positions, feminist agents used family honor and family cohesion filters simultaneously to argue against the dissolution of marriages. Interestingly, family cohesion did not appear as a filter in the personal status codes campaigns, i.e. the campaigns that dealt with family matters most closely. Firmly entrenched within the confessional paradigm where religious leaders continue to maintain jurisdiction on family issues and the private realm, reinforcing patriarchal kinship relations did not become a public affair.

The confessional political filter is activated by Lebanon's complex power sharing system that produces an argument against change and gender equality reform based on fear of upsetting the current demographic balance. Deeply embedded in Lebanon's political structure campaigns targeting nationality reform and personal status codes have agents unable to translate these norms. Personal Status Codes campaigns such as campaign 13/15 that addresses the confessional communities activate the confessional 
political filter. The conflation of politics and religion in the confessional structure of the state has proven to be quite a powerful filter in the translation of the norms of personal status and the nationality campaign. In the campaign for civil marriage laws the delicate issue of the confessional make up of the state made it easy for religious leaders to influence politicians into shying away from instituting a civil marriage law. The patronclient relations that have been produced between religious leaders and politicians as well as those created between politicians and their constituents have been mobilized by the confessional political filter to defeat campaigns on gender equality norms both on the question of civil marriage and in the question of nationality reform. However, in the nationality reform campaign mobilizing the masses for support is proving to be more facile. The confessional political filter in these cases has functioned as a de facto block against the translation of international norms.

The geopolitical filter activated by the international structure appears in the form of a discourse that assumes a clash of civilizations. The argument produced by this filter is twofold and somewhat contradictory. The first maintains that human rights are envisaged within the culture and religion of the local context against a western political conception, the second being an internal ideological argument that opposes secular and religious values. The filter has presented arguments against the implementation of norms and has in fact even produced a change in the norm. The geopolitical filter helps translate gender equality norms in family and marriage against an international structure with feminist agents finding their subject position torn between their right to religion and their right to freedom. It has activists justifying their campaign activity within the confines of 
religion as just implementing the gender equality rights provided for in their framework, but at the same time agents active in these campaigns postulate their commitment to the international conventions against a cultural relativist argument. This has partially translated gender equality norms in personal status codes by limiting the norm to fit within a defined space such as the rights of women in marriage and divorce in Sunni Islam. It has also created a gap between faith-based women's organizations and those called non-sectarian based.

The "in line with the divine" filter is activated against the conflation of religious and political structures in Lebanon and produces an argument that entails the deference to and respect for religion in addressing gender equality norms in family and personal issues. The state and social structure that are both defined by patron client relationships that tie politicians, their constituents, and religious leaders have effected the translation of gender equality norms in personal status codes campaigns. The "in line with the divine" filter permeates both social and confessional structures and similarly translates the norms of the convention within a religious framework. The campaign on women's rights in marriage and divorce in Sunni Islam leans on prescriptions of the right to equality given in marriage contracts of the Sunni Muslim community. The Personal Status Codes campaign 13/15's selection of only addressing custody laws and still imposing gender difference in age of the child due to the "in line with the divine" filter has modified the foundation of the gender equality norm codified in article 16 of CEDAW. Once again the filter produced changes the norms and redefines it to address only the aspects allotted for in that confessional community and without reconstructing the framework. 
Kinship structures tied to patrilineal and patriarchal orders define state and social relations and produce the boundaries of Lebanon's communities. This structure has triggered a culture of belonging filter with an argument against the incorporation of those seen as not being part of this community. In the nationality reform campaigns activists confronted by this filter attempt to reconfigure gender equal nationality norms. The culture of belonging filter has had two effects on the nationality reform campaigns. On the one hand the patrilineal and patriarchal defined structures that have outlined the boundaries of who belongs and who does not have continued to impede the translation of gender equality nationality norms. The other change has been the willingness to redefine these boundaries at the local level within the judicial system.

Lebanon's long history with civil conflict and political instability has affected the push for gender equality norms differently in campaigns both spatially and in time. The culture of violence and political instability have made it more difficult to translate the violence against women norm during times of instability. The campaign for a family violence law was paralyzed by a governmental strike, and overall the issue of combating violence against women was hijacked by the threat of an impending civil war, which placed the issue lower on the scale of important concerns. As a result, women's campaigns have been unable to capitalize on bodily harm frames that have proven to be successful in other international campaigns combating violence against women. During the last era of political stalemate the campaign to draft a domestic violence law could not address the legislative structures of the state, which hindered efforts to initiate any new legislation on the matter. While activists continued to work with other organizations their 
efforts were hampered by the internal conditions of the state. In the nationality campaigns the culture of violence and political instability has forced a reassessment of goals and strategies. Because of the existing law of nationality and the state's ratification of international conventions the campaign found an alternative to addressing gender inequality through the local legal institutions. Unlike the national campaign for the elimination of discrimination against women in the penal code, the campaign on reforming the nationality law changed its strategy and addressed the court at the local level. This allowed it to translate the norm incrementally while the parliament was not in operation. Nationality campaigns have managed to capitalize on this while others have not. The campaigns aimed at introducing new legislation found themselves with their hands tied behind their backs. Their focus remained within the realm of networking, awareness raising, and providing social services while lobbying efforts and passing new legislation became unrealistic.

While several filters appeared in different campaigns across issue areas not all of them had the same impact, what became evident is that some filters proved to be more powerful than others. In this final analysis I categorize the relative power of these filters. The family honor filter metamorphosed the norm of combating violence against women norm and produced parallel discourses on how to address the issue. Its impact while important does not prevent the translation from continuing to take place. The family cohesion filter has also appeared to create multiple translations, but its effect remains ambiguous and translations continue to take place. The filters proven to be most powerful resulting in a blockage of translation are the confessional political and the 
geopolitical filters. These filters when activated have caused a rupture and have prevented any translation of the norms addressed. The "in line with the divine' filter has produced faithless translations as this filter is unable to block entire translations however forces a dissection of the gender equality rights addressed within confessional communities. The culture of belonging filter has left an ambiguous mark on the translation of gender equality in nationality partially due to the ongoing process of translation in that context and the inability to determine the level of entrenchment this filter produces at the social level. In sum, this categorization while indicative of the varying elements of power each filter might provide leaves room for further reading as the translation of these norms continue and activities and projects in these issue areas are ongoing. However, the relative power of filters varies also across time and space and its relation to the force of international and domestic structures. The next section reviews alternate issues that are raised when addressing the role filters play when regional and international forces are mobilized through transnational networks and funding.

International and Regional Influence in Lebanon

The international structure through Western funding and support of reform has created within the women's movement a sense of competition and a focus more on the survival of the fittest as opposed to the commitment to an issue. In reality this has had two results: In the campaigns to reform Lebanon's nationality law it has slowed the progress that could have been achieved had there been unification on the cause. In the case of personal status codes campaigns the lack of funding directed at working within confessional paradigms has also slowed down both the number of projects and the 
sustainability of the campaigns to amend personal status codes. Translating article 16 of CEDAW on the elimination of all forms of discrimination against women in the family and marriage has proven to be more difficult because of the target of the campaigns being the religious leaders and confessional communities that have direct control of private issues. The international gender equality regime is about collapsing the private/public realm and making sure that the personal is political for the advancement of gender equality. However, the women's rights norms campaigns in Lebanon have shown that the personal is political but only to maintain this inequality and continue to strengthen the role of patriarchy and patrilineality as per the confessional political structure of the consociational state.

Both the personal status codes campaign 13/15 and the Nationality is My Right and the Right of My Family campaigns have looked beyond their borders to neighboring countries for guidance and support in the form of networking and in their arguments for reform at the state level. Activists translate gender equality norms against the relevant filters by pointing to countries like Egypt, Algeria, and Morocco that have reformed their nationality laws to be more gender equal and ask politicians why Lebanon is still behind. Just like transnational advocacy networks have found success in leaning on regional and global movements to pressure states into compliance the women's organizations in personal status codes campaigns and nationality reform are attempting to use the same tactics on the home front by including regional amendments in their arguments. The campaigns combating violence against women have not used those measures to help in their draft law on domestic violence; however, they actively network with international 
and regional organizations to raise awareness and train their staff on gender-based violence.

Policy Recommendation and Suggestions for Future Research

The geopolitical filter produced in the campaigns created a lack of collaboration and coordination with faith-based organizations in translating global gender equality norms. On the one hand women's organizations have had to utilize scriptures in formulating their translations of gender equality because of the absence of a uniform civil code outside of the confessional communities; on the other hand, they do make a point of not being Islamic feminists. Reformist and faithful is how they view themselves; however, they agree that working outside of the religious forum eventually would be beneficial for gender equality. Lebanon's case varies from the region because of internal and external politics and its history of being used in proxy wars of the regional and international superpowers and because of its multi confessional makeup. Research on the role of faith based organizations and their relationship to the women's movement and women's rights in Lebanon is needed.

Women's organizations translating the international gender equality norms have relied on the Convention on the Elimination of All Forms of Discrimination against Women in making their case. In this sense all the campaigns resemble each other; but they are related beyond that. In Lebanon women cannot address the nationality laws or the domestic violence issue without addressing women's rights within the family. And while the target of the campaigns can sometimes be the state itself the confessional communities are very much a part of it both through the state's deferral of familial 
concerns to the individual confessions and with the social affiliation to kinship inherently tied to their confessional community. Therefore addressing reform in personal status codes can be defined as the pathway for change in violence against women and in the nationality law. These interconnections are woven into the activities of the women's organizations and are evident in their broadened missions but the need to combine these issues would be helpful to strengthen Lebanon's woman's movement and create more collaboration. For example, the Lebanese Working Women's League has focused on labor laws and personal status laws and has been a primary participant in producing the draft law on domestic violence, the nationality campaigns, as well as campaign 13/15. Such is the case with several organizations that have found it important to collaborate and work across issue areas for broad gender equality. After all denying women the right to pass on their nationality to their husband and children has a deep social and legal effect and is inherently tied to the personal status codes. When husbands and children can only be residents of the state they must acquire residency and work permits. This not only causes economic hardships but in cases of emergency and death they are unable to access their rights to inheritance, property, and coverage of medical expenses.

The global gender equality regime aims to reconfigure the public/private traditional distinction and to ensure women's rights as human rights become the responsibility of the state to uphold. In Lebanon's campaigns on all fronts, the nationality law, combating violence against women, and the personal status codes the state continues to uphold the traditional distinction and has been able to maintain positions of patriarchal power based on confessional authority and the role of the family 
as the basic unit of society. Constitutional deferment of responsibilities to confessional communities and religious leaders has kept women's rights separate from the state and in the hands of religious orders. This has not only kept women in unequal positions with their male counterparts but even among themselves because of the multiple confessional communities with multiple laws applied. Activists believe that as long as there is no uniform civil code that addresses women's rights, gender equality norms in nationality, combating violence against women, and in personal status codes are not achievable. 


\section{BIBLIOGRAPHY}

Abou El Fadl, Khaled. 2002. The Place of Tolerance in Islam, Boston, Massachusetts: Beacon Press

Abu-Lughod, Lila. "Do Muslim Women really Need Saving? Anthropological Reflections on Cultural Relativism and its Others." American Anthropologist 104, no. 3 (Sep., 2002): 783-790.

Lama Abu-Odeh "Crimes of Honor and the Construction of Gender in Arab Societies", In Feminism and Islam: Legal and Literary Perspectives, Mai Yamani ed.141-194 NY: New York University Press, 1997

Julia Adams and Ann Shola Orloff, "Defending Modernity? High Politics, Feminist AntiModernism, and the Place of Gender" Politics and Gender 2005 v. 1

Afshar, Haleh. 1996. "Islam and Feminism: An Analysis of Political Strategies." In Feminism and Islam: Legal and Literary Perspectives, ed. Mai Yamani. NY: New York University Press

Ahmed, Leila. 1992. Women and Gender in Islam: Historical Roots of a Modern Debate. New Haven: Yale University Press

Alvarez, Sonia "Translating the Global: Effects of Transnational Organizing on Local Feminist Discourses and Practices in Latin America", Cadernos de Pesquisa, Vol. 22, (October 2000), 1-27

An-Na'im, Abdullahi A. "The Synergy and Interdependence of Religion, Secularism, and Human Rights: Prospects for Islamic Societies”, Common Knowledge 2005

An-Nai'im, Abdullahi A. "Islam and Human Rights: Beyond the Universality Debate." American Society of International Law 214, (2000): 94.

Asad, Talal 2000, "What do Human Rights Do? An Anthropological Enquiry?" Theory

and Events, Vol 4, Issue 4 
Badran, Margot. "Understanding Islam, Islamism, and Islamic Feminism." Journal of Women's History 13, no. 1 (2001): 47.

Badran, Margot. 1999. "Toward Islamic Feminisms: A Look at the Middle East", in: Hermeneutics of Honor: Negotiating Female "Public" Space in Islamicate Societies, ed. Asma Afsaruddin. Cambridge, Mass.: Harvard University, Center for Middle Eastern Studies.

Barlas, Asma. "Globalizing Equality: Muslim Women, Theology, and Feminism." In On Shifting Ground: Muslim Women in the Global Era, edited by Fereshteh NouraieSimone. New York: Feminist Press at the City University of New York, 2005.

Barlas, Asma. 2002. “Believing Women” in Islam: Unreading Patriarchal Interpretations of the Qur'an, Austin: University of Texas Press.

Basarudin, Azza. "Redefining Feminism/s, Re-Imagining Faith? Margot Badran on Islamic Feminism." Al-Raida XXI, no. 109-110 (Spring/Summer 2005)

Susan Bassnett and Harish Trivedi, Post-Colonial Translation: Theory and Practice, In Translation Studies, Susan Bassnett and Harish Trivedi, eds., NY:Routeledge Publishing, 1999

Bredbenner, Candice L. A Nationality of Her Own: Women, Marriage, and the Law of Citizenship. Berkeley and London: University of California Press, 1998

Bunch, Charlotte , "The Intolerable Status Quo: Violence Against Women and Girls", The Progress of Nations. UNICEF, (1997), 43

Buck-Morss, Susan. Thinking Past Terror: Islamism and Critical Theory on the Left. London New York: Verso, 2003.

Ed. Joseph A. Buttigieg, Antonio Gramsci: Prison Notebooks V. III, Columbia University Press, New York, 1975

Carnegie Arab Political Systems: Baseline Information and Reforms Lebanon www.carnegieendowment.org/arabpoliticalsystems 
Committee on the Elimination of Discrimination against Women, $33^{\text {rd }}$ Session, May 22 , 2005. Concluding comments on Lebanon, p.3

http://www.un.org/womenwatch/daw/cedaw/cedaw33/conclude/lebanon/0545048E.pdf last accessed November 10, 2009

Checkel, Jeffrey, "Norms, Institutions, and National Identity in Contemporary Europe" International Studies Quarterly, Vol. 43, No. 1 (March 1999), pp. 83-114

Claude, Richard Pierre and BurnsH Weston, eds. Human Rights in the World Community: Issues and Action. 2nd ed. ed. Philadelphia: University of Pennsylvania Press, 1992.

Cortell, Andrew P and James W. Davis Jr., "Understanding the Domestic Impact of International Norms: A Research Agenda" International Studies Review, Vol. 2, No. 1, (Spring 2000), pp. 65-87

Deeb, Lara. An Enchanted Modern:Gender and Public Piety in Shi'i Lebanon. Princeton: Princeton University Press, 2006.

Donnelly, Jack. "The Relative Universality of Human Rights" Human Rights Quarterly 29, no. 2 (2007): 281.

Enloe, Cynthia 2000. Bananas, Beaches and Bases: Making Feminist Sense of International Politics, $2^{\text {nd }}$ edition; Los Angeles: University of California Press

Esposito, John L. 1998. Islam: The Straight Path, Oxford, Oxford University Press

Farha, Mark "Demography and Democracy in Lebanon", Mideast Monitor, Vol. 3 No. 1 (January- March 2008) http://www.mideastmonitor.org/issues/0801/0801_2.htm

Finnemore, Martha and Kathryn Sikkink, "International Norm Dynamics and Political Change”, International Organizations, Vol. 52, No. 4, 887-917 (Autumn 1998) 
Forsythe, David P. Human Rights in International Relations, Cambridge, New York, Cambridge University Press: 2006

Freeman, Marsha A. "Women, Law, and Land at the Local Level: Claiming Women's Human Rights in Domestic Legal Systems" Human Rights Quarterly, Vol. 16, No. 3 (Aug., 1994), pp. 559-575

Friedman, Elizabeth Jay, "Gendering the Agenda: The Impact of the Transnational Women's Rights Movement At the UN Conferences", Women's Studies International Forum, Vol. 26, No. 4. 313-331, 2003

General recommendation 21 of the committee adopted by the General Assembly go to http://www.unhcr.org/refworld/category,LEGAL,CEDAW,„,48abd52c0,0.html last accessed February $5^{\text {th }}, 2009$

Ghai, Yash. "Universalism and Relativism: Human Rights as a Framework for Negotiating Inter-Ethnic Claims." Cardozo Law Review 21, (2000): 1095.

Gunew, Sneja "Feminist Cultural Literacy: Translating Differences, Cannibal Options", Ilha do Desterro, Florianopolis, 44(July 2003), 153-180, also available at http://www.periodicos.ufsc.br/index.php/desterro/article/view/7426/6808

Hayeon Lee "Join the Facebook group 'All for Civil Marriage in Lebanon': The future of civil marriage in Lebanon maybe in the hands of a facebook group."NOW Lebanon, August 21, 2008 http://www.nowlebanon.com/NewsArticleDetails.aspx?ID=55684 last accessed February 17, 2009

Ronald Ingelhart and Pippa Norris, "Modernization and Gender Equality: A Response to Adam and Orloff", Politics and Gender v. 1, no. 3, 2005

Ronald Ingelhart and Pippa Norris, "The True Clash of Civilizations", Foreign Policy, March/April 2003

Joachim, Jutta. "Framing Issues and Seizing Opportunities: The UN, NGOs, and Women's Rights”, International Studies Quarterly, v. 47(2003), 257 
Joseph, Suad. "Teaching Rights and Responsibilities: Paradoxes of Globalization and Children's Citizenship in Lebanon”, Journal of Social History, v. 38 no. 4 (Summer 2005) p. 1007-26

"The Public/Private: The Imagined Boundary in the Imagined Nation/State/Community: The Lebanese Case" Feminist Review, No. 57, (Autumn 1997) p. $73-92$

"Gender and Citizenship in the Arab World, Mediterranean Development Forum, UNDP: 2002

Joseph, Suad. Civil Myths, Citizenship, and Gender in Lebanon. In Suad Joseph, (ed.) Gender and Citizenship in the Middle East. Syracuse: Syracuse University Press. Pp 107136.

Joseph, Suad ed. Gender and Citizenship in the Middle East, Syracuse, NY Syracuse University Press: 2000

Kaplan, Cora, Joan Wallach Scott, and Debra Keates eds. Transitions, Environments, Translations, (NY:Routledge Publishing, 1997)

Fatmeh Kaddourah, Lamia Rustum Shehadeh, and Aman Kabbara Chaarani, "Women's Rights in Marriage and Divorce in Islam", Committee for the Follow Up of Women's Issues, Lebanon 2006

Kardam, Nuket "The Emerging Global Gender Equality Regime from Neoliberal and Constructivist Perspectives in International Relations", International Feminist Journal of Politics, Vol. 6, No.1, 85- 109

Karns, Margaret P. and Karen A. Mingst, International Organizations: The Politics and Processes of Global Governance, Boulder and London: Lynne Reiner Publishers, 2004

Keck, Margaret and Kathryn Sikkink. Activists Beyond Borders : Advocacy Networks in International Politics. Ithaca N.Y.: Cornell University Press, 1998. 
Khalaf, Samir 2002 Civil and Uncivil Violence in Lebanon: A History of the Internationalization of Communal Conflict, NY: Columbia University Press

Khatoun Haydar, "The Lebanese Women Movement: Problematic and Priorities" Project for the Strengthening of the Lebanese Civil Society http://afkar.omsar.gov.lb/English/SiteMenu/Publications/Pages/Khatoun\%20Hyadar\%20 Eng.asx

Ghada Khouri, "Caught in the Middle: Women in Lebanon." WIN Magazine. 4 December, 2001. http://www.geocities.com/Wellesley/3321/win13b.htm last accessed January 26th 2009

Lewis, Bernard 1994. Islam and the West, Oxford, Oxford University Press

Mahdawi, Dalila, “One woman's fight against Lebanese nationality law”, Daily Star Magazine August 2009

http://www.dailystar.com.lb/article.asp?edition_id=1\&categ_id=31\&article_id=108455

Mahdawi, Dalila, "Ministerial statement fails to address nationality law", Daily Star Magazine November 21, 2009

Mahdawi, Dalila, "Activists press Cabinet to work toward granting women nationality rights”, Daily Star Magazine November 26, 2009

http://www.dailystar.com.lb/article.asp?edition_id=1\&categ_id=1\&article_id=109121

Mahmood, Saba. Politics of Piety: The Islamic Revival and the Feminist Subject.

Princeton N.J.: Princeton University Press, 2005.

Maynard, Mary. Researching Women's Lives from a Feminist Perspective. London Bristol PA: Taylor Francis, 1994.

Mernissi, Fatima. 1985. Beyond The Veil: Male-Female Dynamics in Modern Muslim Society. Saki Books Publisher, London

Mernissi, Fatima. 1991. The Veil and the Male Elite: A Feminist Interpretation of Women's Rights in Islam. Tr. Mary Jo Lakeland. Addision-Wesley. 
Mir- Hosseini Ziba, Understanding Islamic Feminism: Interview with Ziba Mir Hosseini, Association For Women's Rights in Development, Madrasa Reforms in India, February 24, 2010 last accessed March 30 2010 http://www.awid.org/Issues-and-

Analysis/Library/Understanding-Islamic-Feminism-Interview-with-Ziba-Mir-Hosseini

Mir-Hosseini, Ziba. 1996. "Women and Politics in Post-Khomeini Iran: Divorce, Veiling, and Emerging Feminist Voices." In Women and Politics in the Third World, ed. Haleh Afshar.London and New York: Routledge.

Mir-Hosseini, Ziba. 1999. Islam and Gender: The Religious Debate in Contemporary Iran. Princeton: Princeton University Press.

Ministry of Social Affairs (MOSA) and Lebanese Council to Resist Violence Against Women (LCRVAW) "Guide Book for Training Sessions Involving Prevention Against Domestic Violence.” Publication 2005.

Moghadam, Valentine M. Towards Gender Equality in the Arab/Middle East Region: Islam, Culture, and Feminist Activism Human Development Report Office, UnitedNationsDevelopmentProgramme, 2004, http://hdr.undp.org/docs/publications/background_papers/2004/HDR2004_Valentine_Mo ghadam.pdf.

Mohanty, Chandra. "Under Western Eyes: Feminist Scholarship and Colonial Discourses" Feminist Review, No. 30, (Autumn 1988): 61-88

Mojab, Shahrzad. "Theorizing the Politics of 'Islamic Feminism'." Feminist Review no. 69, The Realm of the Possible: Middle Eastern Women in Political and Social Spaces (Winter, 2001): 124-146.

Nordeste, Brian "Negotiating the Human Rights Debate: Re-Imagining Human Rights Beyond the Geopolitical Divide", Paterson Review: Journal of International Affairs, V. 6,2005

Nouraie-Simone, Fereshteh, ed. On Shifting Ground : Muslim Women in the Global Era. New York: Feminist Press at the City University of New York, 2005. 
Ofeish, Sami A. "Lebanon's second republic: secular talk, sectarian application "Arab Studies Quarterly (ASQ). 21.1 (Wntr 1999): 97(2).

The Office of the High Commissioner for Human Rights page on the Convention on the Elimination of All Forms of Discrimination Against Women.

http:// www2.ohchr.org/english/bodies/ratification/8.htm accessed November 12th 2008

“Thinking the Unholy Unthinkable: Lebanon" The Economist. March 28, 1998, p.45

Ramazanoglu, Caroline. Feminist Methodology : Challenges and Choices Sage Publications, 2002.

Recommendations of the committee to eliminate all forms of discrimination against women http://www.un.org/womenwatch/daw/cedaw/recommendations/recomm.htm Regional Bureau for Arab States United Nations Development Programme, Women are Citizens too: The Laws of the State, the Lives of Women, 2002

Reiman, Kim "A View from the Top: International Politics, Norms and the Worldwide Growth of NGOs", International Studies Quarterly, Vol. 50, (2006),

Maurus Renkowski and Sofia Saadeh, "A nation divided: Lebanese confessionalism" in Ed. Haldun Gulalp Citizenship and Ethnic Conflict: Challenging the nation-state, Routledge Research in Comparative Politics, Routledge NY 2006

Rustum-Shehadeh, Lamia, Women and War in Lebanon, Gainesville, FL, University of Florida Press: 1999

Rustum-Shehadeh, Lamia, "The Legal Status of Married Women in Lebanon", International Journal of Middle East Studies, v. 30, no. 4 (Nov. 1998), 501-519

Rustum-Shehadeh, Lamia, “Coverture in Lebanon”, Feminist Review, 76, (2004), p.83-99

Said, Edward 1994. Orientalism, New York,Vintage Books Edition 
Said, Edward 1997. Covering Islam: How the media and experts determine how we see the rest of the world, New York, First Vintage Books Edition

Seminar on Gender Equity in Lebanon, October $11^{\text {th }}$ and $12^{\text {th }} 2005$ Proceedings Report www.undp.org.lb/mdgs/discussions/GEinLeb2005.doc last accessed January $26^{\text {th }} 2009$

Tabet, Gihane "Women in Personal Status Laws: Iraq, Jordan, Lebanon, and Syria", Social and Human Sciences Papers in Women's Studies/Gender Research, No. 4, 2005 portal.unesco.org/shs/fr/files/8090/11313662721Women_in_Personal_Status_Laws.pdf/ Women_in_Personal_Status_Laws.pdf

Thomas Risse-Kappen, Steve C. Roppe, and Kathryn Sikkink, The Power of Human Rights: International Norms and Domestic Change, Cambridge: Cambridge University Press, 1999

Tsing, Ana Lowenhaupt Transitions as Translations, In Transitions, Environments, Translations Cora Kaplan, Joan Wallach Scott, and Debra Keates eds., 255-58, NY: Routledge Publishing, 1997

Salem, Paul "Lebanon Takes Steps To End Political Stalemate" National Public Radio, May 21, 2008 http://www.npr.org/templates/story/story.php?storyId=90694409\&ps=rs

Salibi, Kamal A House of Many Mansions: The History of Lebanon Reconsidered, Berkeley, CA University of California Press: 1988.

Shachar, Ayelet, “Group Identity and Women's Rights in Family Law: The Perils of Multicultural Accomodation", The Journal of Political Philosophy, Vol.6 No. 3, 1998, p. 285-305.

Smith, Rogers M. Civic Ideals: Conflicting Visions of Citizenship in U.S. History. New Haven, CT : Yale University Press, 1997

Sunder, Madhavi. "Enlightened Constitutionalism." Connecticut Law Review 37, (2005): 891-905. 
"Piercing the Veil." In Just Advocacy? : Women's Human Rights, Transnational Feminisms, and the Politics of Representation, edited by Wendy S. Hesford and Wendy Kozol. New Brunswick, N.J.: Rutgers University Press, 2005.

Usta, Jinan, Jo Ann M. Farver, and Nora Pashayan, "Domestic Violence: The Lebanese Experience", Public Health, 121, no. 3, : 2007, pp. 208-219

The United Nations Fourth World Conference on Women, Beijing, China - September 1995 Action for Equality, Development and Peace, Platform for Action; http://www.un.org/womenwatch/daw/beijing/platform/human.htm

Wadud, Amina. 1999. Qur'an and Woman: Rereading the Sacred Text from a Woman's Perspective, 2nd Edition. Oxford: Oxford University Press.

Waltz, Susan 2004. "Universal Human Rights: The Contribution of Muslim States." Human Rights Quarterly, Vol. 26:4, 799-844.

Waltz, Susan 2002. "Reclaiming and Rebuilding the History of the Universal Declaration of Human Rights," Third World Quarterly vol. 23:3, 437-448.

Jeanne Ward et al. GLOBAL: Broken Bodies, Broken Dreams: violence against women exposed, November 2005, UN office in Nairobi, Kenya. OCHA/IRIN Publication, also available online at http://www.irinnews.org/IndepthMain.aspx?IndepthId=59\&ReportId=72831

Willis, Katie, The Theory and Practice of Development. Routledge Perspectives, 2004. Women's Affairs Section to letter No. 50214 (89-9) from the Special Rapporteur on violence against women.

Workman, Anna "Interview with Lina Abou-Habib, Director of Collective for Research and Training on Development-Action (CRTD-A) in Lebanon", Women's Learning Partnership, March 4, 2006.

http://www.learningpartnership.org/citizenship/2006/08/lahinterview030406/

Mai Yamani ed. Feminism and Islam: Legal and Literary Perspectives, (NY: New York University Press, (1997) 
Young, Iris Marion. "The Logic of Masculinist Protection: Reflections on the Current Security State." Signs 29, no. 1 (Autumn, 2003): 1-25.

Marie-Joelle Zahar "Power Sharing in Lebanon: Foreign Protectors, Domestic Peace, and Democratic Failure," in Sustainable peace: power and democracy after civil wars, ed. Philip G. Roeder and Donald Rothchild (New York: Cornell University Press, 2005), $219-240$

Zuhur, Sherifa "Empowering Women or Dislodging Sectarianism? Civil Marriage in Lebanon", Yale Journal of Law and Feminism, Vol. 14:1 (Summer 2002), 177-208

Zwingel, Suzanne. How do international women's rights norms become effective in domestic contexts? An analysis of the Convention on the Elimination of all Forms of Discrimination against Women (CEDAW), Bochum University Dissertation 2005

Yacoubian, Mona "Facing the Abyss: Lebanon's Deadly Political Stalemate" United States Institute of Peace, Lebanon Working Group, February 2008 http://www.usip.org/resources/facing-abyss-lebanons-deadly-political-stalemate

"2 Dead as Shiites, Sunnis Clash in Lebanon: Street Battles Erupt In Beirut As Sectarian Violence Evokes Bitter Memories of Civil War" CBS World News, Beirut Lebanon May 8, 2008 http://www.cbsnews.com/stories/2008/05/08/world/main4080303.shtml

Lebanon, Country Backgrounder Series, Project on Middle East Democracy http://www.pomed.org/docs/Lebanon_Backgrounder.pdf

"Can You Name 16 Forms of Gender Violence? 16 days of Activism Against Gender Violence 25 November- 10 December" United Nations Population Fund http://www.unfpa.org/public/cache/offonce/news/events/16days;jsessionid=EDE6A0ED C71FDF916C5091B12E0EE34D

The Inter-American Convention on the Nationality of Women, 49 Stat. 2957, Treaty Series 875, December 26, 1933 http://avalon.law.yale.edu/20th_century/intam02.asp

Lebanese Council to Resist Violence Against Women, www.lebanesewomen.org

KAFA: Enough Violence And Exploitation, www.kafa.org.lb 


\section{RITA A. SABAT}

1997

B.B.A., Business Administration University of Massachusetts- Amherst. Amherst, MA

M.A., International Studies Florida International University (FIU)

Miami, Florida

2004-2009

Teaching Assistant/ Instructor of Record Department of International Relations, FIU

Special Events Representative Providence, Rhode Island

\section{PRESENTATIONS}

Sabat, Rita (2006) "The Sudanese Displaced in the Arab Republic of Egypt: Providing Protection for Refugees." War Crimes and International Responsibility: Human Rights, Law, and Governance Conference, Miami, FL, February 23-24.

Sabat, Rita (2005) "Security and Civil Society: Egypt's Struggle for Sovereignty." International Studies Association Southern Region 2005 Annual Conference, Miami, FL, November 3-5.

\section{GRANTS/AWARDS}

Graduate Assistant, Department of International Relations, FIU. January 2004-Fall 2007, Academic year 2008-2009

Jack D, Gordon Institute for Public Policy and Citizenship Studies, FIU. Field Research Funding, \$1600: 2007

Exxon Foundation Scholarship, International Relations Department, FIU, \$5000: 2008 
Florida International University Dissertation Year Fellowship, University Graduate School, \$25,000: 2009-2010 